MARCELO APARECIDO PELEGRINI

\title{
A REGULAÇÃO DAS COOPERATIVAS DE ELETRIFICAÇÃO
}

\author{
RURAL
}

Tese apresentada à Escola Politécnica da Universidade de São Paulo para obtenção de Título de Doutor em Engenharia. 
Tese apresentada à Escola Politécnica da Universidade de São Paulo para obtenção do título de Doutor em Engenharia.

Área de Concentração:

Sistemas de Potência

Orientador:

Prof. Titular Fernando Selles Ribeiro 
Pelegrini, Marcelo Aparecido

A regulação das cooperativas de eletrificação rural. São Paulo, 2003.

$156 \mathrm{p}$.

Tese (Doutorado) - Escola Politécnica da Universidade de São Paulo. Departamento de Engenharia de Energia e Automação Elétricas.

1.Cooperativas de eletrificação rural 2.Regulação de serviços públicos 3.Distribuição de energia elétrica I.Universidade de São Paulo. Escola Politécnica. Departamento de Engenharia de Energia e Automação Elétricas II.t. 
A meus pais, Osmar e Geralda, por seu constante amor e apoio.

A Andrea, minha eterna fonte de amor e inspiração.

E para Letícia, minha pequena, minha grande paixão.

A mais pura dedicação do autor. 


\section{AGRADECIMENTOS}

A meus irmãos, Mauricio e Márcia, Neno e Marina. Que Deus nos ilumine e proteja.

À Comissão de Serviços Públicos de Energia - CSPE, pela disponibilização dos dados, pelas amizades e por todas as oportunidades de aprender o difícil ofício da regulação. Agradeço o exemplo dos Comissários Zevi Kann, Marcos Roberto Gouvêa, Fernando Amaral de Almeida Prado e Moacyr Trindade de Oliveira Andrade. Em especial o Comissário e meu professor na Escola Politécnica Carlos Márcio de Oliveira Tahan, pelas valiosas observações sobre o trabalho.

Ao amigo Anderson da Silva Jucá, meu companheiro na sistematização dos dados e nos estudos do processo de regulação das cooperativas de eletrificação rural.

Aos amigos da Aneel, Jandir, Sebastião, Marcelino e Elmo, pelos dados e importantes discussões, ensinamentos e incentivos.

Aos companheiros da Unesp e da USP no trabalho de inspeção das cooperativas de São Paulo, em especial os amigos Luiz Henrique, Luiz Fernando, Octávio e Miguel, também incansáveis batalhadores da causa da universalização.

Aos companheiros do cooperativismo de eletrificação rural paulista, em particular, Paulo Celso e João Bosco, pela ajuda na compreensão do papel das cooperativas.

Ao Enerq e a todos que, direta e indiretamente, contribuíram para a realização deste trabalho.

E, sobretudo, ao amigo, mestre e orientador Fernando Selles Ribeiro, pela imensa paciência, dedicação e exemplo de vida.

O agradecimento sincero do autor. 


\section{SUMÁRIO}

\section{LISTA DE FIGURAS}

LISTA DE TABELAS

RESUMO

ABSTRACT

CAPÍTULO 1 - INTRODUÇÃO .....................................................................1

1.1 BRASILEIROS SEM LUZ: PODEM CONTAR COM A COOPERATIVA DE

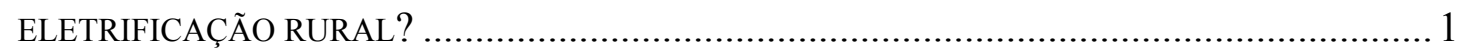

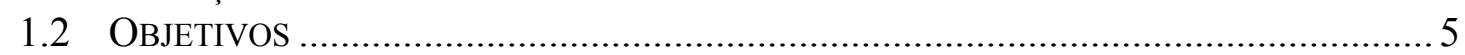

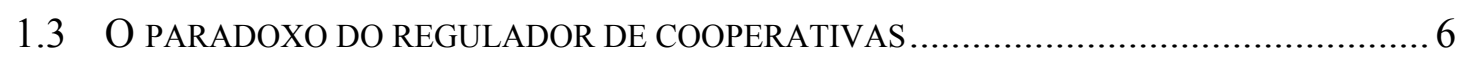

CAPÍTULO 2 - A CONSOLIDAÇÃO DAS COOPERATIVAS DE

ELETRIFICAÇÃ̃ RURAL NO SÉCULO XX....................................................8

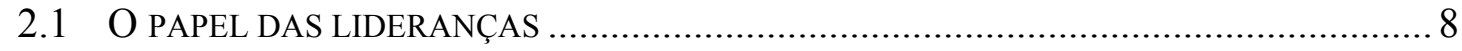

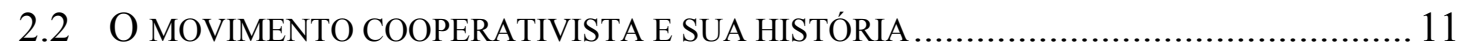

2.3 AS COOPERATIVAS DE ELETRIFICAÇÃO RURAL ….............................................. 15

2.4 A REGULAÇÃO DAS COOPERATIVAS: DO CÓDIGO DE ÁGUAS À CONSTITUIÇÃO

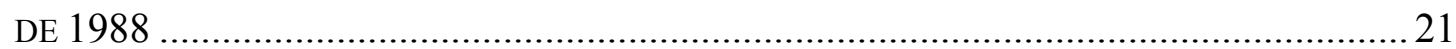

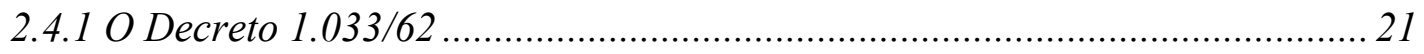

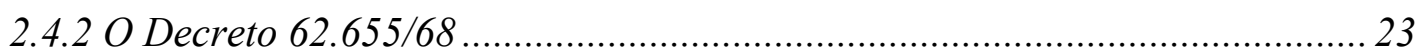

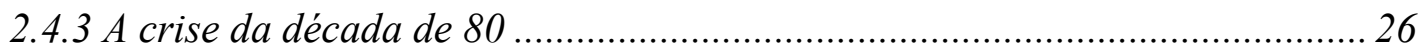

2.5 O TRADICIONAL CONCEITO DE PERMISSIONÁRIA …............................................... 28

CAPÍTULO 3 - DA NOVA REPÚBLICA AO ESTADO NEOLIBERAL................ 30

3.1 A ESTAGNAÇÃO DA ELETRIFICAÇÃO RURAL ........................................................ 30

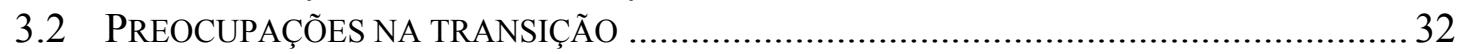

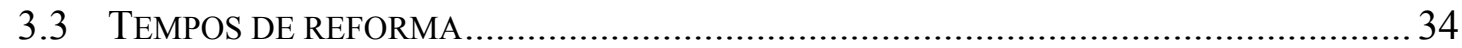

CAPÍTULO 4 - AS COOPERATIVAS NO NOVO QUADRO

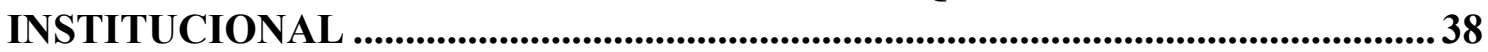

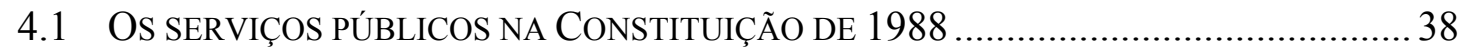

4.2 O SERVIÇO PÚBLICO CONCEDIDO NA REESTRUTURAÇÃO DO SETOR ELÉTRICO .......43

4.3 AS PROPOSTAS DO PROJETO RESEB PARA AS COOPERATIVAS DE

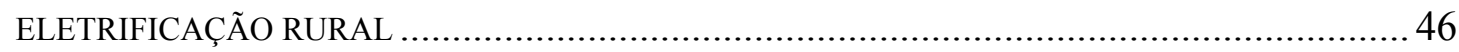

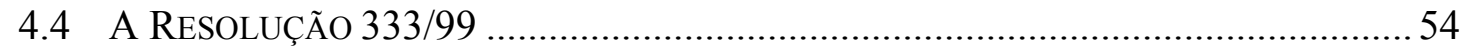

CAPÍTULO 5 - PESQUISADORES CHAMADOS PARA PENSAR E CONDUZIR O PROCESSO DE CONHECIMENTO DA SITUAÇÃO

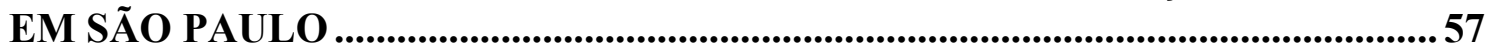

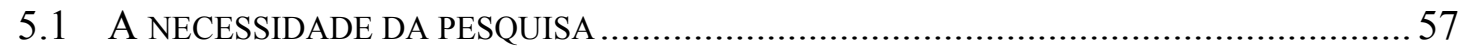

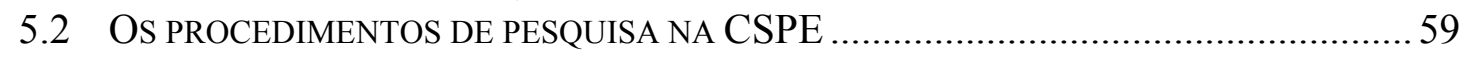




\section{CAPÍTULO 6 - AS COOPERATIVAS DE ELETRIFICAÇÃO RURAL EM}

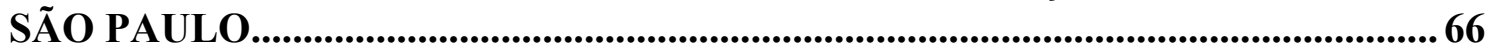

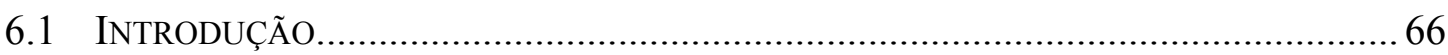

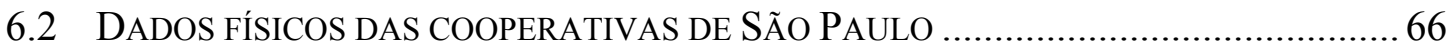

6.3 DADOS DO MERCADO DAS COOPERATIVAS DE SÃO PAULO ................................. 71

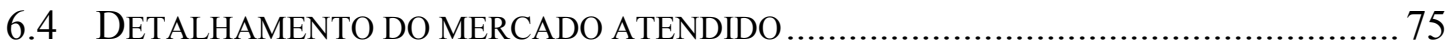

6.4 .1 - CEDRAP

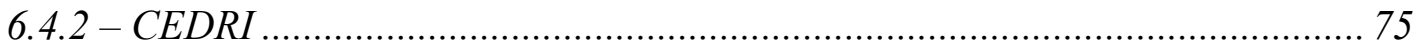

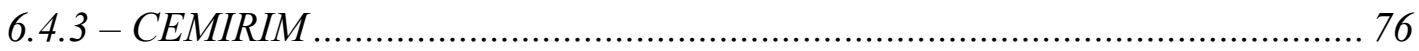

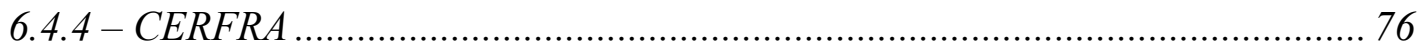

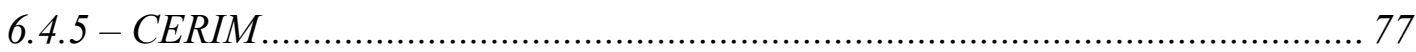

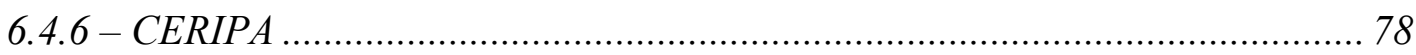

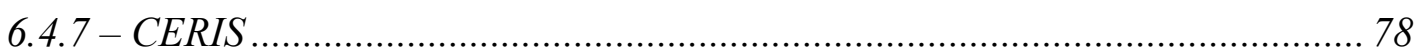

6.4.8-CERMC

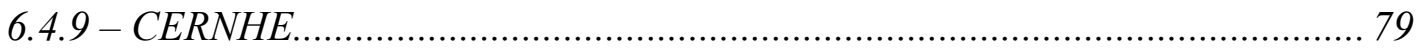

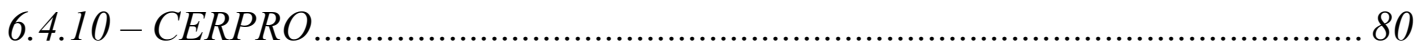

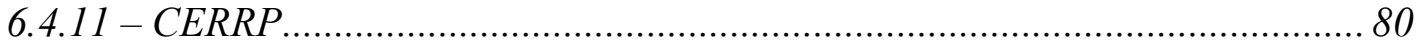

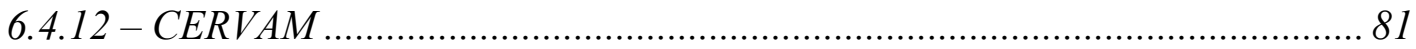

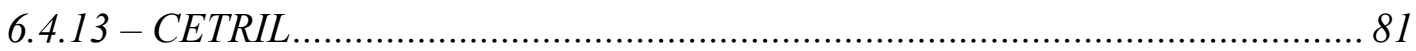

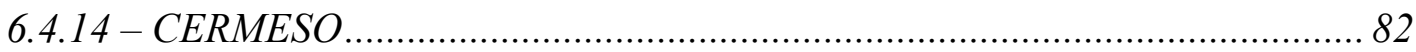

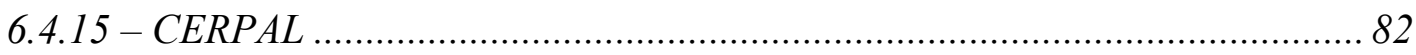

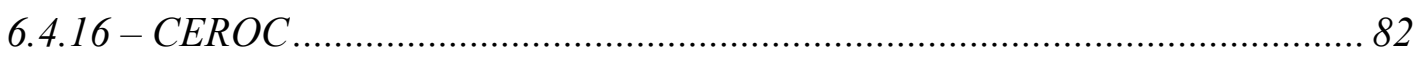

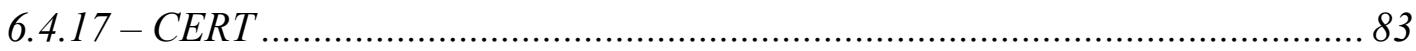

CAPÍTULO 7 - O DIAGNÓSTICO DAS COOPERATIVAS DE

ELETRIFICAÇÃO RURAL PAULISTAS .............................................................8 84

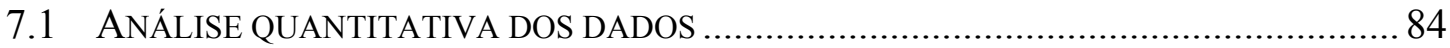

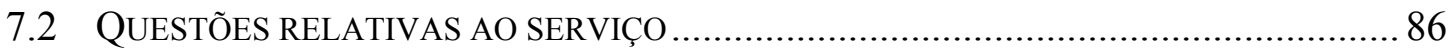

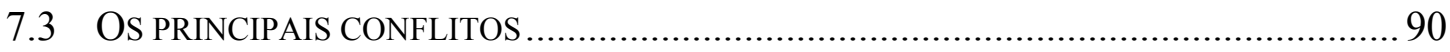

CAPÍTULO 8 - OS CONFLITOS REGULATÓRIOS ..............................................94

8.1 O PROCESSO DE REGULARIZAÇÃO - 2000/2001 …............................................... 94

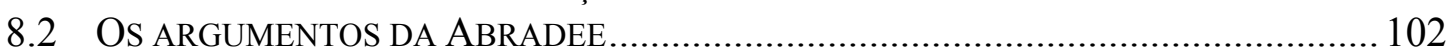

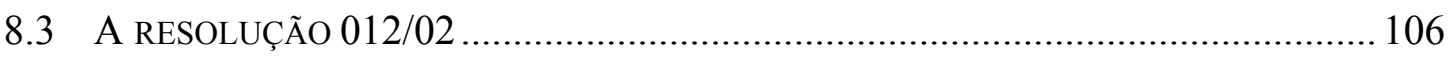

8.4 AS DEMARCAÇÕES DE ÁREAS EM SÃo PAULO ................................................... 108

8.5 CONCLUSÕES DA CSPE SOBRE O ENQUADRAMENTO DAS COOPERATIVAS DE

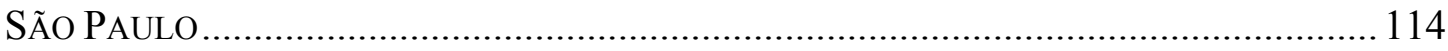

CAPÍTULO 9 - AS COOPERATIVAS NA SOMBRA ............................................. 115

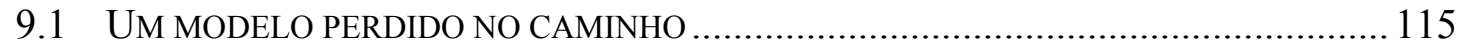

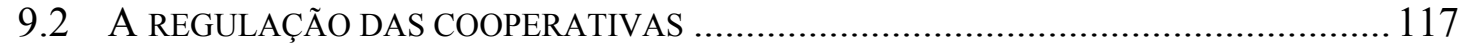

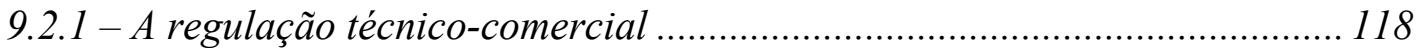

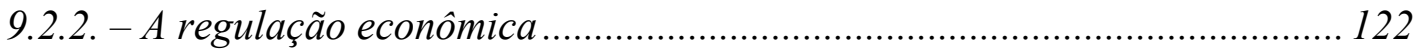

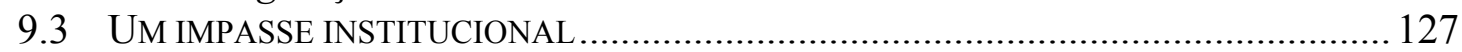

9.4 O BRASIL REGULADO, O BRASIL NÃO-REGULADO........................................... 132

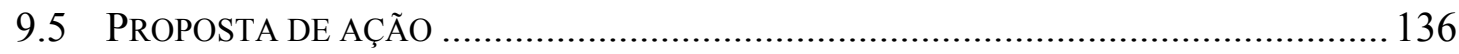


CAPÍTULO 10 - CONSIDERAÇÕES FINAIS

10.1 REGULARIZAR OU NÃO REGULARIZAR?

10.2 AS COOPERATIVAS DE ELETRIFICAÇÃO RURAL E A UNIVERSALIZAÇÃO DO

ATENDIMENTO 142

10.2.1 O debate da universalização 142

10.2.2 A omissão das cooperativas de eletrificação rural no debate da universalização. 146

10.3 OS INSTRUMENTOS DA PERMISSÃO E AUTORIZAÇÃO COMO FOMENTO À UNIVERSALIZAÇ̃̃O. 148

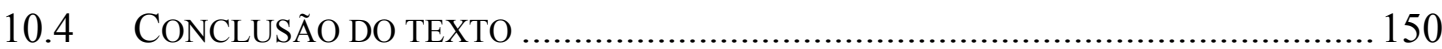

REFERÊNCIAS BIBLIOGRÁFICAS ..................................................................... 152 


\section{LISTA DE FIGURAS}

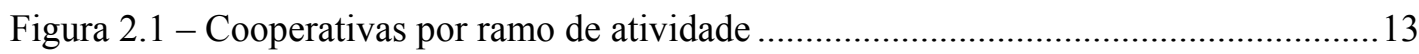

Figura 2.2 - Número de cooperados por ramo de atividade ................................................. 14

Figura 2.3 - Número de empregados por ramo de atividade .................................................

Figura 2.4 - Cooperativas por região - dezembro de 2001 ............................................... 15

Figura 6.1 - Municípios com instalações de cooperativas.....................................................68

Figura 6.2 - Comparativo entre as extensões de rede das cooperativas ...............................69

Figura 6.3 - Comparativo entre o número de transformadores das cooperativas ..................70

Figura 6.4 - Comparativo entre a potência instalada das cooperativas .................................70

Figura 6.5 - Comparativo da demanda média das cooperativas ..........................................72

Figura 6.6 - Comparativo da energia distribuída das cooperativas ......................................72

Figura 6.7 - Comparativo do número de consumidores das cooperativas ............................73

Figura 6.8 - Comparativo do número de consumidores das cooperativas .............................74

Figura 7.1 - Comparativo: Energia vendida x Consumidores das cooperativas....................85

Figura 7.2 - Conflitos: cruzamentos de rede em Mogi Mirim.............................................91

Figura 7.3 - Conflitos: cruzamentos de rede em São José do Rio Preto................................92

Figura 7.4 - Conflitos: paralelismo de rede em Porto Ferreira .............................................92

Figura 8.1 - Quadro demonstrativo da negociação de áreas entre cooperativa e

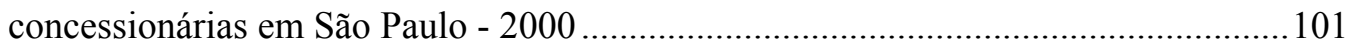

Figura 8.2 - Limites naturais: matas, plantações de eucaliptos e áreas de preservação.......110

Figura 8.3 - Limites naturais: rios, córregos e ribeirões................................................... 110

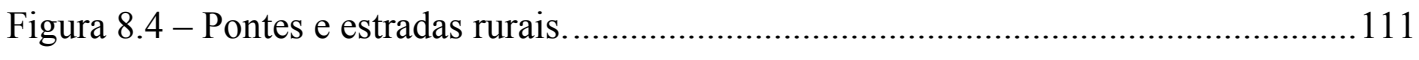

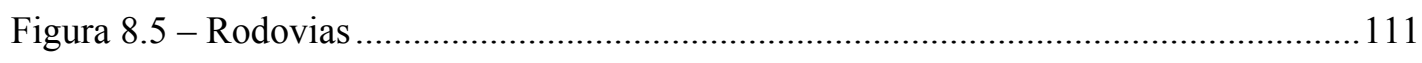

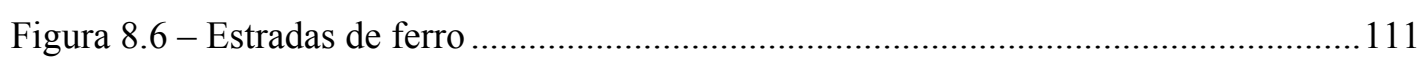

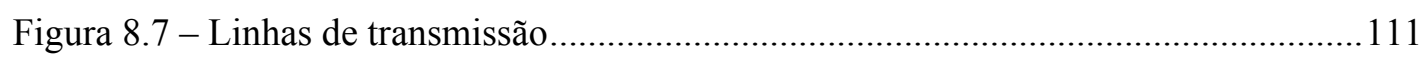

Figura 8.8 - Pontos extremos da rede de distribuição ........................................................112

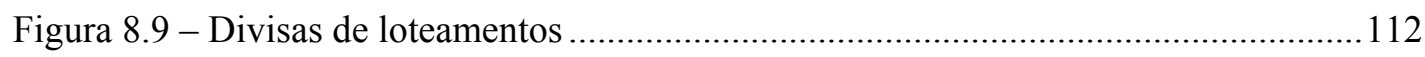

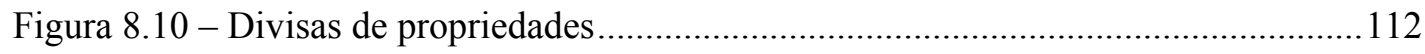

Figura 8.11 - Marco de divisa de municípios .................................................................. 112

Figura 8.12 - Cruzamentos de redes de distribuição ..........................................................113 


\section{LISTA DE TABELAS}

Tabela 2.1 - Dados dos Sistemas de Distribuição nos EUA ..................................................18

Tabela 6.1 - Supridoras e municípios sede das cooperativas .................................................67

Tabela 6.2 - Dados Físicos da rede das cooperativas de São Paulo .......................................69

Tabela 6.3 - Dados do Mercado das cooperativas de São Paulo .............................................71

Tabela 6.3 - Dados de Faturamento das cooperativas de São Paulo ......................................74

Tabela 7.1 - Índices técnicos das cooperativas de São Paulo .................................................. 86

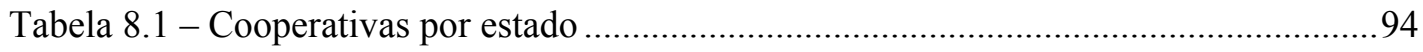

Tabela 8.2 - Intersecções entre cooperativas e concessionárias em São Paulo. ………….....97 


\section{RESUMO}

As cooperativas de eletrificação rural são agentes que sempre estiveram à margem do setor elétrico e que agora devem se regularizar, adaptando-se aos condicionantes do serviço público de energia elétrica decorrentes da Lei de Concessões de 1995. Este trabalho faz a avaliação do aparato de regulação das atividades das cooperativas de eletrificação rural brasileiras e da política pública de regularização aplicada em São Paulo. O foco da avaliação é o cidadão rural, o cidadão que consome energia elétrica, e o cidadão que está ainda excluído do acesso ao serviço de eletricidade. A interpretação do problema e o estudo do processo de regularização levaram à constatação da existência de uma situação de impasse. Demonstra-se a tese de que a atitude do órgão regulador perante a tarefa que a lei the impõe cria um paradoxo em que as cooperativas são deixadas fora do alcance da regulação, com prejuízo maior para o cidadão que mora em sua área de atuação. Em particular, no momento em que todo brasileiro acaba de ganhar a garantia do seu direito de acesso à eletricidade, o cidadão que mora na área das cooperativas não tem a proteção do Estado para fazer valer esse seu direito. $\mathrm{O}$ trabalho oferece uma proposta acadêmica de alternativa de saída para esse impasse institucional, baseada na busca do equilíbrio entre os agentes. 


\title{
THE RURAL ELECTRIC COOPERATIVES REGULATION
}

\begin{abstract}
The rural electric cooperatives are agents who have always been on the edge of the electric sector. Now, they must be regularized to the new rules of the electric energy public service established by the 1995 Concessions Law. This work provides an evaluation of the Brazilian rural electric cooperatives regulation apparatus and the regularization public policy applied in São Paulo. The evaluation focus is the rural citizen, the electric energy consumer and the citizens who have been excluded from this public service. The interpretation of the problem and the study of the regularization process has led to the evidence that the situation reached an impasse. The thesis is that the attitude of regulatory agencies create a paradox where the cooperatives are not covered by the regulation policies with damage to citizens in these areas. Particularly, given that the Brazilian citizens have won the right of electricity access, the citizen who lives in the cooperative area have no protection by State to do this right effective. This work offers an academic proposal to break this institutional impasse, based on the search of the agents' equilibrium.
\end{abstract}




\section{CAPÍTULO 1 - INTRODUÇÃO}

\subsection{Brasileiros sem luz: podem contar com a cooperativa de eletrificação rural?}

Onze milhões de brasileiros ainda vivem sem luz elétrica em 2003, dos quais 90 \% vivem com renda familiar menor do que três salários mínimos. Oito em cada dez vivem na zona rural e não constituem um mercado interessante para as concessionárias de energia tanto pela pobreza, quanto pela dispersão no campo, e baixa perspectiva de consumo, mas principalmente porque a concessionária não gosta mesmo de fazer eletrificação rural. Esses números são os oficiais do momento, não há certeza sobre eles, como nunca houve. O Ministério de Minas e Energia acredita que seja um número mínimo que pode ser usado para planejamento de políticas públicas. O próprio Ministério, em 1999, falava que havia 5.000 .000 de propriedades rurais no Brasil sem luz, $73 \%$ do total. Nesse ano, foi lançado um grande programa de eletrificação rural, pretendendo levar energia para 1.000 .000 de novos consumidores em três anos. Findo o prazo, e tendo sido ligadas 600.000 propriedades rurais, afirma-se hoje que devem restar 2.500 .000 propriedades por eletrificar. Há grande desconhecimento sobre uma população muito pobre que está na zona mais esgarçada do tecido social brasileiro.

Há, no imaginário nacional, a idéia de que as cooperativas de eletrificação rural podem ser a salvação da lavoura. O Brasil acostumou-se a chamá-las de permissionárias e ainda as chama. E acredita que elas podem ter a dedicação necessária para levar energia onde a concessionária não chega, e que essa dedicação é natural delas, tanto pelo seu caráter comunitário de cooperativa, quanto por ser administrada por gente da terra, sensível às necessidades, conhecedora das dificuldades do pobre rural.

O pioneirismo das cooperativas de eletrificação rural justifica essa imagem. As cooperativas de eletrificação rural são, realmente, uma instituição simpática ao povo. Isto ocorre no mundo todo, e ocorre também no Brasil. Particularmente, em 
São Paulo, algumas cooperativas conseguem ter um atendimento melhor que o das concessionárias vizinhas, digno de elogios espontâneos.

Esta tese trata, no fundo, de dois assuntos pelos quais o autor, por mais que queira ser isento no procedimento científico, veste a camisa e faz parte da torcida de apoio: eletrificação do público de baixa renda e cooperativa de eletrificação rural. Mas seria possível fazer pesquisa sem amor à causa?

Atendendo uma demanda do Banco Nacional de Desenvolvimento Econômico e Social - BNDES - que desejava saber porque o proprietário rural de baixa renda fica quase sempre fora do público efetivamente atendido por programas de eletrificação rural, o Departamento de Engenharia de Energia e Automação Elétricas da Escola Politécnica da Universidade de São Paulo constituiu um grupo de pesquisadores sobre o tema eletrificação rural, dentro de seu Grupo de Energia GEPEA. Já em 1989 teve apoio da Secretaria de Ciência e Tecnologia para um grande projeto de pesquisa multidisciplinar. Depois, com trabalho apoiado pelo Banco de Desenvolvimento do Rio Grande do Sul - BADESUL -, depois BANRISUL, participou do planejamento e avaliação de um programa nesse estado. A experiência foi adaptada para o estado de São Paulo, sempre com o apoio do BNDES, dando origem ao Programa "Luz da Terra", baseado no modelo que ficou conhecido por modelo BNDES/USP. Privilegiava o baixo custo da ligação e não permitia a exclusão social: o acesso à energia tinha que ser barato e permitido a todos os cidadãos.

Em São Paulo, o custo de uma instalação rural na área da Eletropaulo custava US\$20.000,00. A CESP tinha feito uma grande experiência com circuitos simplificados, ligando cerca de 15.000 consumidores a US\$ $3.500,00$ por ligação. O Programa "Luz da Terra" já ligou 20.000 consumidores a um custo muito menor: R\$ 2.000,00. A pesquisa foi fundamental, o trabalho de acompanhamento também e o autor participou da equipe responsável pela consecução desses resultados.

Entretanto, as cooperativas de eletrificação rural ficaram à margem do Programa "Luz da Terra". Estavam presentes às discussões, sempre presentes nas 
solenidades políticas, mas, apenas uma cooperativa arregaçou as mangas e pôs-se a trabalhar.

Em 1999, o GEPEA se reuniu para participar da regulação das cooperativas de eletrificação rural na audiência pública nacional sobre a proposta de regularização das cooperativas, e apresentou uma proposição que sintetizava a opinião do grupo de estudos que estreava nas lides da regulação.

O grupo de estudos, inclusive o autor, entendia que as cooperativas eram fundamentais para o desenvolvimento rural, e que o setor elétrico deveria criar as condições de sobrevivência delas. Todavia, elas "estavam precisando de um 'puxão de orelhas' (sic), pois não estavam com vontade de trabalhar nos programas de eletrificação rural, e não estavam trabalhando, cumprindo sua obrigação de levar a energia para moradores da área rural, mesmo não tendo que fazer investimentos para isso." Propunha o GEPEA que elas fossem obrigadas pela regulação a participar de programas de eletrificação rural operacionalizados pelos governos em sua área de atuação.

A idéia foi aplaudida pelas lideranças de cooperativas presentes. $\mathrm{O}$ professor foi cumprimentado por tais líderes pela imagem do "puxão de orelhas", reconhecida por eles como bastante apropriada.

A proposta de obrigar a fazer eletrificação rural não foi incluída pela agência reguladora, que preparava outra forma de fazer com que todos que distribuem energia no Brasil sejam obrigados a atender, por sua conta, a todos os cidadãos brasileiros.

Em 2002, o Congresso Nacional elaborou e aprovou a Lei da Universalização dos Serviços de Energia Elétrica.

Não se fala mais em eletrificação rural no Brasil; fala-se em universalização do atendimento. $\mathrm{O}$ tema deixa de ser tratado segundo os textos tradicionais e passa a depender do texto da lei recém-elaborada. A literatura internacional de eletrificação rural ainda não conhece o termo universalização do atendimento. Recentemente, em 
maio de 2003, na XIX Conferência Latinoamericana de Eletrificação Rural - CLER - realizada em Cuba, houve dificuldade para fazer com que entendessem o que está começando a acontecer no Brasil: como atender a todos sem que o cliente tenha que pagar pela ligação. Era uma inovação brasileira.

Também, na XIX CLER ficou muito claro que a sobrevivência das cooperativas de eletrificação rural é bastante ameaçada no modelo de mercado neoliberal. No Chile, por exemplo, as cooperativas estão mudando de ramo, fazendo outros serviços adequados à sua estrutura empresarial, e vendendo suas instalações elétricas para as concessionárias. Houve uma mudança na regulação que permite essas outras atividades e facilita a transferência de parte ou todo o ativo elétrico. Também a regulação das cooperativas no novo ambiente econômico liberal é algo pouco tratado na literatura.

O autor percorreu o interior do estado de São Paulo fomentando a eletrificação rural, indo às comunidades, indo a campo. Foi ficando claro que as cooperativas de eletrificação rural têm "jeitinho especial”, tanto para influir nas decisões políticas, quanto para sempre acabar permanecendo à margem do setor elétrico. Que, por sinal, não era o seu habitat natural. As cooperativas eram da área da agricultura. Em teoria, teriam passado para a Energia.

Não é bem assim. São mal recebidas pelo setor elétrico, que as quer engolir. E vão ficando na sombra, sem reclamar.

Não têm obrigações com o serviço público de energia elétrica, vivendo uma situação particular: os cidadãos que são atendidos por uma cooperativa de eletrificação rural não têm os mesmos direitos que um cidadão atendido por uma concessionária. Ficaram à margem da regulação.

O programa de eletrificação rural do governo brasileiro foi lançado para concessionárias distribuidoras e cooperativas. Porém, o fundo que o sustenta só se tornou viável para as cooperativas depois de três anos. Ficaram à margem. 
Ficaram à margem, também, da obrigação que todas as concessionárias passaram a ter de promover o atendimento universal por sua própria conta.

Quietas, à sombra. Cooperativas à sombra e onze milhões no escuro.

\subsection{Objetivos}

Este documento relata os resultados de um conjunto de atividades de pesquisa realizadas tanto na academia, quanto no campo - tomado com o sentido bucólico de área rural. O autor foi fomentador de política de eletrificação rural, fez acompanhamento da operacionalização de programa estadual, implementou atividades comunitárias de facilitação de eletrificação rural, debateu com agentes locais, inclusive políticos. Depois, inspecionou cooperativas de eletrificação rural como membro das equipes contratadas pela agência de regulação para essa tarefa.

Mais tarde, foi profisssional militante da regulação do setor elétrico, trabalhando especificamente com regulamentação de cooperativas de eletrificação rural.

O objetivo deste trabalho acadêmico foi fazer avaliação do aparato de regulação das atividades das cooperativas de eletrificação rural e da política pública de regularização desses agentes, dois temas correlatos que estão abertos ao debate nacional, e que fazem parte do campo de pesquisa do autor, dentro da Escola Politécnica.

A sua dissertação de mestrado já era sobre avaliação de política pública de eletrificação rural e outras publicações suas versam sobre o tema. $\mathrm{O}$ autor foi bolsista desse tema, pesquisador desse tema, e, pela via do concurso público foi parar nos quadros da agência estadual de regulação dos serviços de energia, onde foi designado para esse mesmo tema.

Quis a vida que, por alguns anos, ele trabalhasse na militância da regulação - o que significa estar militando em atividades inovadoras, na fronteira do conhecimento - e, simultaneamente, continuasse seu trabalho de doutoramento no 
mesmo assunto da eletrificação de zonas rurais. Esta é uma particularidade deste trabalho de pesquisa: a investigação científica se dava na Escola como, também, no cotidiano da atividade profissional, em contemporaneidade, sobre os mesmos interesses de construir conhecimentos teóricos para aplicação na prática profissional, em "continuum".

O foco desse conjunto de interesses é muito claro e objetivo: o cidadão rural, o cidadão que consome energia elétrica, e o cidadão que está ainda excluído da distribuição dessa riqueza nacional pelo evidente motivo de estar excluído da distribuição de todas as riquezas nacionais.

\subsection{0 paradoxo do regulador de cooperativas}

A primeira etapa do trabalho foi tomar conhecimento da situação. São Paulo foi o primeiro lugar onde a política pública de regularização de cooperativas de eletrificação rural lançou-se à prática e deu a partida. Foram feitas pesquisas sobre todas as cooperativas do estado, com inspeções de campo em cada uma. Obteve-se uma massa enorme de informações, coletadas em trabalho conduzido por pesquisadores da área de energia da Unesp e da USP, do citado grupo de pesquisa sobre eletrificação rural, tema do autor desde que se deu por engenheiro e pesquisador.

Os dados de cada cooperativa inspecionada foram reunidos em relatórios individuais, sendo em seguida feita a sistematização das informações obtidas. Mesmo quando funcionário da agência estadual de regulação, nunca deixou de ser um investigador da eletrificação rural que sempre procurava publicar os avanços parciais conseguidos em fóruns científicos nacionais e internacionais.

A análise do problema com o olhar da regulação exigiu a pesquisa histórica. A regulação do setor elétrico foi se modificando ao longo dos anos e, junto com ela, as cooperativas de eletrificação rural. A passagem das cooperativas pela sua história constitui um processo político. A leitura desse processo revela uma capacidade de sobrevivência indomável. As cooperativas de eletrificação rural, agentes que sempre 
esteviveram à margem do setor, agora enfrentam o desafio da regularização perante o serviço público de energia elétrica.

A interpretação do problema posto e o estudo do processo de regularização levaram à constatação da existência de uma situação de impasse. Pretendendo demonstrar a tese de que a atitude do órgão regulador perante a tarefa que a lei lhe impõe cria um paradoxo em que as cooperativas são deixadas fora do alcance da regulação, com prejuízo maior para o cidadão que mora em sua área de atuação, e como contribuição dirigida aos que também se interessam em estudar o mesmo tema, o autor oferece uma proposta acadêmica de alternativa de saída para esse impasse institucional.

O momento político dá à questão da universalização do atendimento uma força inequívoca. Qualquer saída para tal paradoxo será permeada pelo debate da obrigação de atender que a lei impõe a quem distribui energia, pela obrigação de regulamentar e fiscalizar o cumprimento do acesso universal à energia que a lei impõe à agência de regulação, e pelo debate da inclusão social que subiu a rampa do Planalto, espraiou-se pela Esplanada e declaradamente instalou-se no ministério formulador das políticas públicas de energia. Incorporar o cidadão da área da cooperativa de eletrificação rural ao serviço público é também uma ação de universalização. Que os agentes do estado saibam todos usar essa força. 


\section{CAPÍTULO 2 - A CONSOLIDAÇÃO DAS COOPERATIVAS DE ELETRIFICAÇÃO RURAL NO SÉCULO XX}

\subsection{O papel das lideranças}

As cooperativas de eletrificação rural são frutos do pioneirismo.

Crescem na seara do cooperativismo, florescem sob lideranças expressivas, marcantes, voluntariosas, empreendedoras.

São fruto da força da liderança, mais que da força dos cooperados. Vingam onde há lideres competentes.

As cooperativas de eletrificação rural também são frutos da ordem conservadora. Ao analisar "Casa Grande e Senzala", Darcy Ribeiro diz que o traço mais característico do brasileiro da classe dominante é o mandonismo.

Cabe perfeitamente.

As cooperativas de eletrificação rural floresceram junto com o fortalecimento do Estado brasileiro, atuando justamente em um setor que foi sendo paulatinamente dominado pelo Estado, durante cinqüenta anos. Desde as discussões do pós-guerra que deram origem ao projeto de desenvolvimento do Brasil baseado na atuação do Estado em algumas áreas estratégicas, dando origem ao BNDES, à Petrobrás e à Eletrobrás no segundo governo de Vargas, a gestão do setor de energia foi se transferindo para a mão de técnicos profissionais altamente competentes, obedecendo ao comando político de operadores encastelados nos governos, detentores do poder real sobre a máquina administrativa.

As cooperativas de eletrificação rural eram um elo entre a engrenagem estatal, técnica no discurso e política no comando, e a fina flor da dominação econômica local, marcada pela iniciativa privada agrícola. 
Maria Sylvia de Carvalho Franco (1997) ao analisar as relações de poder, no mesmo espaço geográfico que serviu para a atuação das cooperativas rurais, porém, cem anos antes, na época da formação do Estado brasileiro, deparou-se com uma ambigüidade onde se confundiam as esferas da vida pública e da vida privada. Reparou ela que o Estado era visto no meio rural do interior de São Paulo como "propriedade" do grupo social que o controlava e usado como tal:

"O aparelho governamental nada mais é que parte do sistema de poder desse grupo, imediatamente submetido à sua influência, um elemento para o qual ele se volta e utiliza sempre que as circunstâncias o indiquem como o meio adequado." (FRANCO, 1997, pg.142)

Embora esse texto seja referente ao Segundo Império - e nada tenha, seguramente, a ver com as decisões do setor de energia elétrica do pós-guerra - e os atuais senhores da terra sejam trinetos dos senhores que, então, usavam o seu poder que imaginavam ser quase feudal para que o serviço público concedesse vantagens especiais a suas atividades privadas, fica sempre uma curiosidade:

Porque a cooperativa de eletrificação rural sempre parece estar escapando, com vantagens, da regulação que incide sobre as concessionárias?

As cooperativas foram chegando onde a concessionária ainda não tinha chegado. Com senhores de terra precisando de energia e sem uma resposta adequada da concessionária, era absolutamente natural que uma solução alternativa, com a nobreza e as virtudes da cooperativa, fosse privilegiada pelos detentores do poder, alguns da mesma origem geográfica e social. Durante muitos anos elas eram subordinadas ao Ministério da Agricultura, apesar de serem distribuidoras de energia elétrica.

As cooperativas, onde elas se sustentaram, foram uma solução para o acesso à luz elétrica. Com a aproximação das concessionárias, aprofundou-se um conflito existencial.

Um ponto pouco analisado é que esse conflito foi se passando em um ambiente conservador. $\mathrm{Na}$ década de 50 foram sendo constituídas empresas estatais de energia elétrica, de início, as geradoras. Mas, logo os governos estaduais 
começaram um movimento de incorporação das empresas distribuidoras. As soluções foram variadas e as empresas distribuidoras estaduais ficaram diferentes entre si. Diferentes na engenharia, diferentes na gestão, diferentes no trato da expansão para a zona rural. Diferentes nas relações com as cooperativas de eletrificação rural e diferentes nos procedimentos políticos e administrativos.

Os conflitos que iam surgindo eram entre "lavradores" - classe dominante rural - e empresas estatais, dominadas pelo mesmo extrato político-conservador, embora com gestão técnica de especialistas em distribuição.

O mandonismo rural durou institucionalizado até 1930; um dos atributos positivos à ascensão de Getúlio Vargas é considerada justamente a nova ordem institucional, sepultando a Velha República e permitindo a modernização do Estado. Acontece que os próprios poderosos da Era Vargas não se desfizeram do papel anterior, principalmente em suas áreas de influência. A política no interior pouco mudou, nem em nomes mudou, adaptou-se para se preservar. Alguns desses políticos ainda tinham poder enquanto o setor elétrico foi se consolidando.

Veio a ditadura militar e fortaleceu a ordem conservadora. As cooperativas se multiplicaram nesse tempo, por motivos que serão analisados. Era comum o tema das cooperativas de eletrificação rural ser tratado como uma coisa de colegas no gabinete do Ministro de Minas e Energia Engenheiro Aureliano Chaves.

Então, quando as cooperativas se viam em situações de conflito, na grande maioria das vezes era conflito com empresas do governo. Era, pois, conflito com opção de solução política, política tomada pela perspectiva que dela têm as classes dominantes.

A reforma liberal do Estado dos anos 90 trouxe situações novas. O Estado fortaleceu o aparato da regulação; no entanto, a concessionária deixou de ser controlada pelo governo. O conflito continuou, mais ou menos pelas mesmas causas, sem embargo, com outros parâmetros. Porém, a opção de resolver a contenda com a concessionária pela pressão dos amigos no governo deixou de existir. 
Todavia, a opção da pressão política não deixou de existir. Está aí uma constatação que permeia o desenvolvimento deste trabalho: as cooperativas de eletrificação rural sempre sobrevivem por meio de um componente político muito forte.

\subsection{0 movimento cooperativista e sua história}

A organização de pessoas que se unem em torno de um objetivo comum, de forma colaborativa ou cooperativa, é um movimento que encontra ecos por toda a história humana. Segundo Rech (2000), em várias sociedades antigas encontram-se traços de organizações semelhantes a cooperativas, mas a primeira organização formal de uma delas deve-se aos "Pioneiros de Rochdale". A crônica de Rochdale, no Reino Unido, registra em 1844 uma iniciativa que fez da cidade o marco inicial do cooperativismo. Ali,

“... 28 tecelóes reuniram-se em sociedade para, de forma associativa, tentar minorar os efeitos maléficos da Revolução Industrial sobre suas vidas, através da formação de uma sociedade que faria compras comuns e negociaria conjuntamente a produção de seus membros." (BECHO, apud SOUTO; LOUREIRO, 1999, pg. 59)

Os Pioneiros de Rochdale elaboraram uma série de princípios, que depois foram adotados pelos Congressos de Organizações Cooperativas (OCB, 2002):

- Garantia de livre acesso e adesão voluntária, sem discriminação.

- Busca de controle, organização e gestão democrática, baseado no princípio um homem, um voto, independente do número de quotas-parte possuídas na cooperativa.

- Participação econômica igualitária ou limitada a um certo número de quotas, com as sobras (não existe o lucro) sendo aplicadas prioritariamente em reservas da própria cooperativa.

- Exercer autonomia e independência, sob controle de seus associados, sem ter que se submeter ao Estado e evitando se tornar reféns de financiadores. 
- Buscar a educação, capacitação e informação de seus membros, principalmente sobre a prática e os benefícios do cooperativismo.

- Cooperar com outras cooperativas, através de estruturas que congreguem as cooperativas em centrais, federações ou confederações, visando fortalecer o movimento cooperativista.

- Demonstrar interesse pela comunidade, através de políticas aprovadas pelos membros.

Os bons resultados da experiência de Rochdale logo levaram à expansão e formação de diversas cooperativas pelo mundo, sempre em uma tentativa de corrigir, em parte, o sistema capitalista liberal. Hoje, existem cooperativas com diferentes propósitos, por exemplo: consumo, agropecuárias, de crédito, de pesca, habitacionais, de eletrificação rural, educacionais, de saúde, de trabalho, etc. Em especial, na agricultura, o modelo encontrou grande aderência, por trazer ganhos econômicos na venda dos produtos aos pequenos agricultores que se associavam. Ainda hoje, na atual economia globalizada, é extremamente comum, em todo o mundo, que o setor agrícola se organize em cooperativas distintas.

O movimento cooperativista disseminou-se, principalmente na Europa e Estados Unidos. Na Inglaterra e Suécia, 50 \% das famílias estão ligadas a cooperativas de consumo. Nos EUA, $22 \%$ da população é cooperativada, com destaque para as cooperativas de crédito, e $98 \%$ da área rural é atendida por cooperativas de eletrificação. Na França, 25 \% da população é cooperativada, na Argentina $20 \%$, e na Índia $10 \%$ (RECH, 2000). No Brasil, segundo a OCB (Organização das Cooperativas Brasileiras), em outubro de 2001 havia 7.026 cooperativas, com cerca de 4,8 milhões de cooperados, aproximadamente $3 \%$ da população brasileira, e mais de 175.000 empregados.

A OCB classifica as cooperativas brasileiras em 12 ramos de atividade: agropecuário, consumo, crédito, educacional, especial, infra-estrutura, habitacional, mineral, produção, saúde, trabalho e turismo e lazer. 
As cooperativas de eletrificação rural se enquadram dentro do ramo de infra-estrutura ${ }^{1}$. As figuras $2.1,2.2$ e 2.3 mostram, por ramo de atividade, a quantidade de cooperativas, cooperados e empregados. O maior número de cooperativas é de trabalho, um setor que experimentou grande expansão nos últimos anos. As de consumo têm maior número de cooperados, enquanto as do setor agropecuário empregam mais trabalhadores.

Figura 2.1 - Cooperativas por ramo de atividade

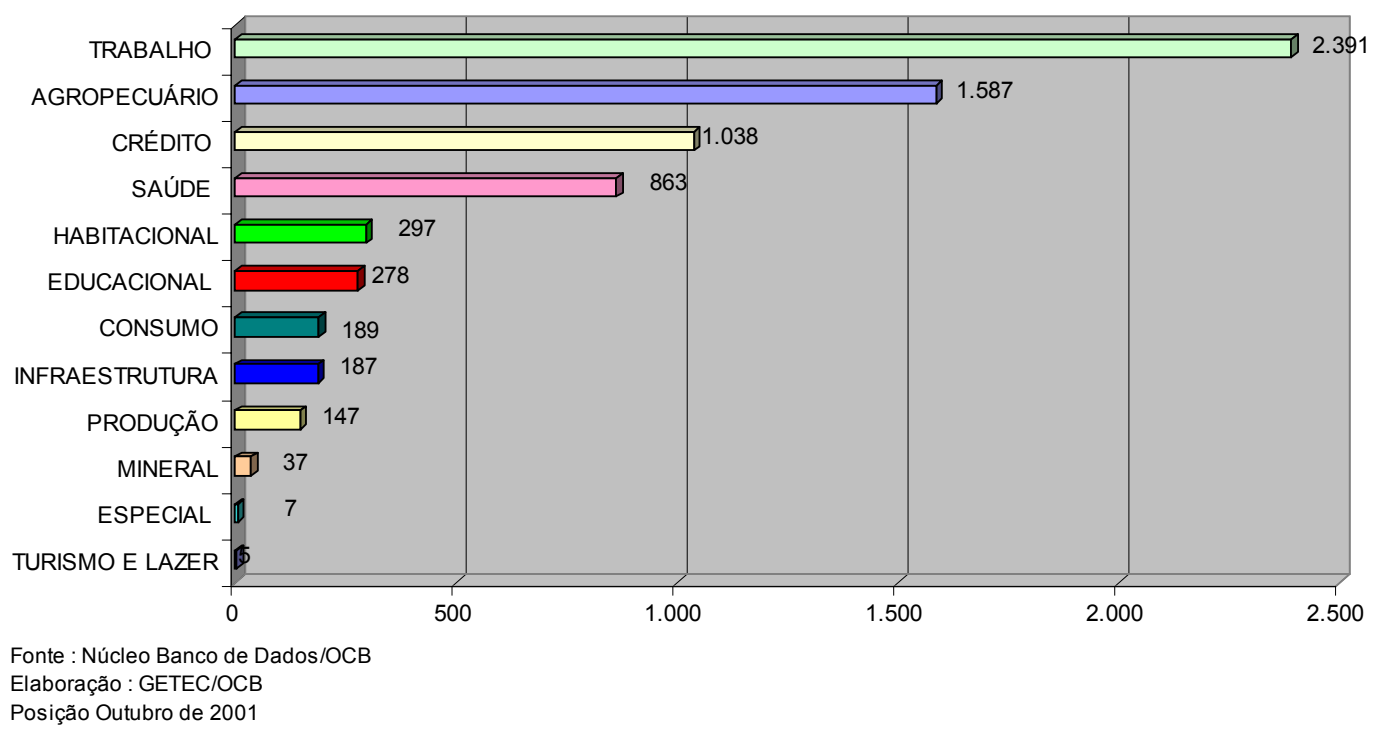

\footnotetext{
${ }^{1}$ Na prática, esse ramo só engloba as cooperativas de eletrificação rural.
} 
Figura 2.2 - Número de cooperados por ramo de atividade

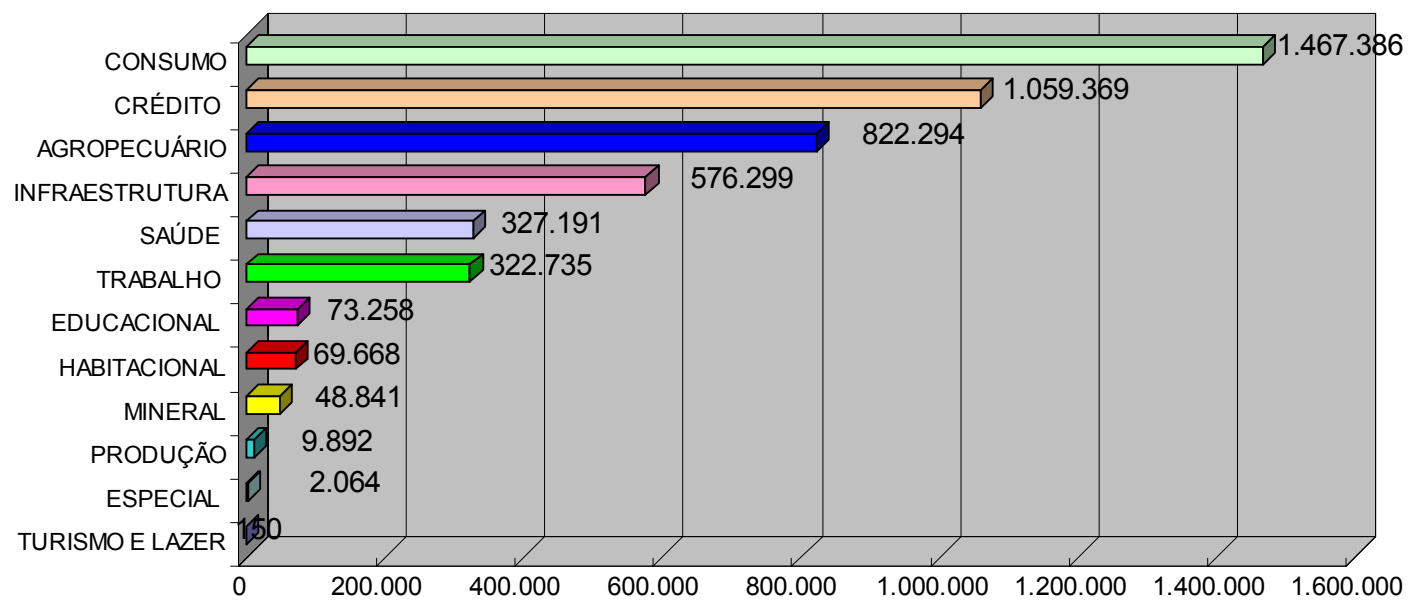

Fonte : Núcleo Banco de Dados/OCB

Elaboração : GETEC/OCB

Posição Outubro de 2001

Figura 2.3 - Número de empregados por ramo de atividade

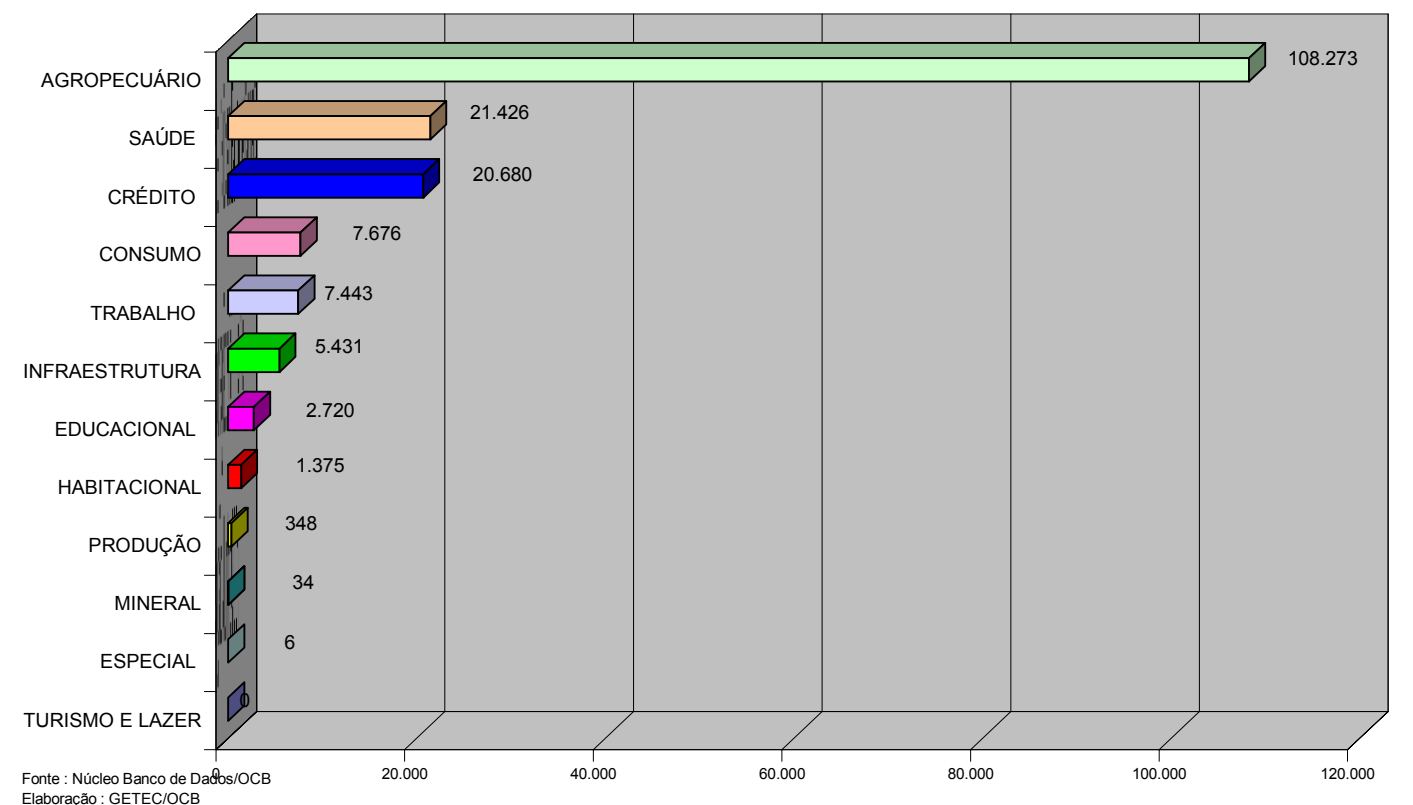


Quanto à distribuição regional, a maioria se concentra no Sudeste e no Sul, como se pode ver na figura 2.4 , a seguir.

Figura 2.4 - Cooperativas por região - dezembro de 2001

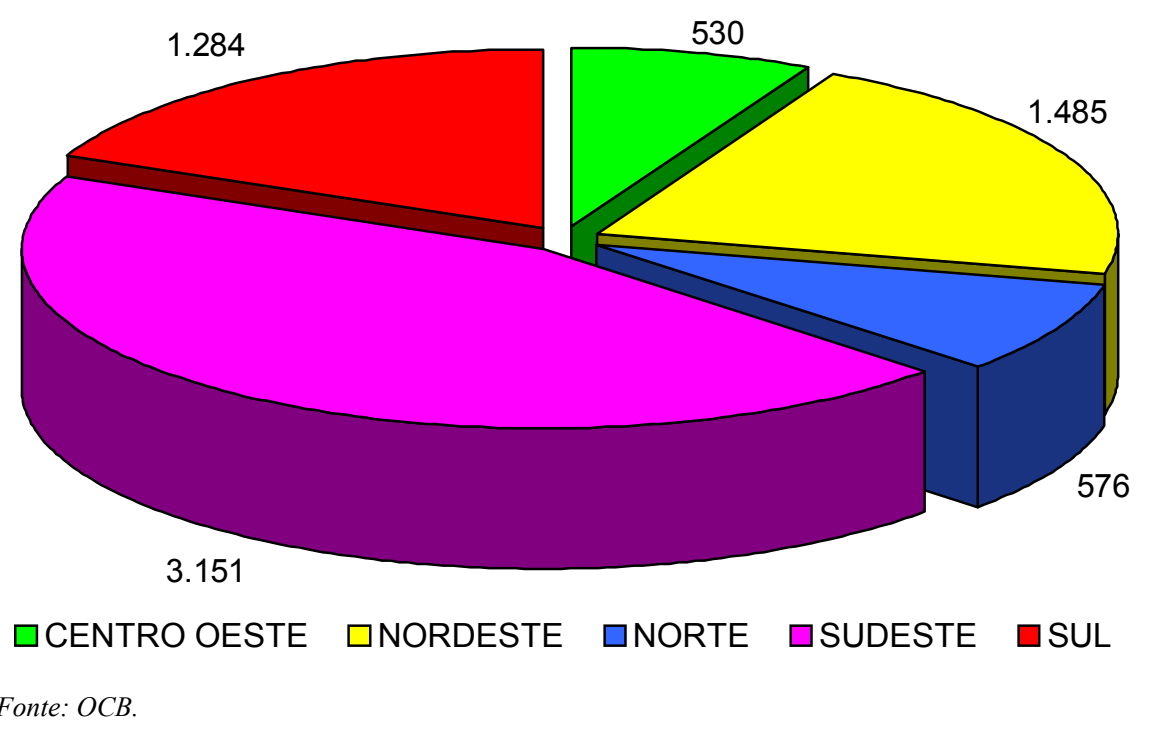

A força do movimento cooperativista é particularmente grande no campo. As cooperativas respondem por $62 \%$ da produção de trigo, aproximadamente $40 \%$ da produção de cevada, aveia e algodão e $30 \%$ da produção de suínos, soja e café (OCB, 2002).

A Constituição Federal dá abrigo às cooperativas, sendo elas regidas pela Lei Federal 5.764/71. A lei lhes concede incentivos fiscais.

As cooperativas de eletrificação rural, tema deste trabalho, é um conceito que foi trazido por uma experiência internacional que teve sucesso em alguns países, e grandes dificuldades de sobrevivência em outros.

\subsection{As cooperativas de eletrificação rural}

A eletrificação de áreas rurais sempre foi um dos maiores desafios para o desenvolvimento econômico e para o serviço público de distribuição de energia elétrica. Os sistemas de distribuição, em todo o mundo, se formaram ao redor de núcleos urbanos. 
O pioneirismo, tipicamente, se dá no interior. A primeira rede de distribuição brasileira foi instalada em Campos dos Goitacazes, Rio de Janeiro. Em São Paulo, a primeira cidade com energia elétrica foi Rio Claro, pouco depois da Lei Áurea. Em uma de suas últimas aparições públicas, presidindo o ato de instalação do Programa de Eletrificação Rural "Luz no Campo" no Palácio dos Bandeirantes, em maio de 2000, o engenheiro Mário Covas chama a atenção para o caráter de interior que acompanha o pioneirismo da luz elétrica. Mas, marotamente, sugere que Rio Claro já deveria ter sido a escolhida por influência de Ulisses Guimarães...

A finalidade primeira dos sistemas de energia elétrica foi concorrer com os sistemas de iluminação a gás. A primeira aplicação da energia elétrica foi na iluminação de centros urbanos, primeiro com lâmpadas a arco voltaico e posteriormente com lâmpadas incandescentes. Logo, o sistema utilizado para fornecer energia às lâmpadas que iluminavam as ruas e praças estava sendo usado para levar energia às casas e industrias, onde as crescentes aplicações da energia elétrica (principalmente força motriz, aquecimento e iluminação) transformaram, juntamente com os vários usos do petróleo e do automóvel, o modo de vida da sociedade, marcando a chamada $2^{\mathrm{a}}$ Revolução Industrial.

$\mathrm{O}$ atendimento de concentrações populacionais urbanas traz ganhos de escala à indústria, e barateia o acesso e o uso da energia pelas pessoas. Já o atendimento a núcleos esparsos ou rurais demanda investimentos cujo retorno é bem maior e este é um dos principais motivos da má vontade das concessionárias e das próprias cooperativas de eletrificação rural com investimentos para atender um público pobre e disperso (RIBEIRO, 1993).

No início da década de 30 do século passado já estava bastante difundido o uso da eletricidade mas, na maioria dos países desenvolvidos, o campo permanecia às escuras.

A grande crise do sistema capitalista acontecera em 1929. O modelo liberal de organização econômica tinha chegado ao colapso e não conseguia dar respostas à Grande Depressão. Foi quando, nos EUA, o recém-eleito governo Roosevelt implantou o New Deal, um plano que preconizava a intervenção do Estado como 
empreendedor e incentivador de obras públicas para reerguer a economia e combater os efeitos da grande crise.

Um dos principais aspectos do New Deal era o uso de recursos públicos para realizar obras que empregassem a população, de modo a reativar os processos produtivos da economia. Na área rural, foi dada grande prioridade à eletrificação de todo o interior americano. Num primeiro momento, tentou-se que as empresas distribuidoras locais realizassem a expansão do serviço. Como se tratava de explorar um mercado pouco rentável, não houve interesse delas na questão. A saída encontrada foi, através de um órgão federal, a REA $^{2}$ (Rural Electrification Administration), incentivar a formação de cooperativas que construíssem, operassem e mantivessem o sistema de distribuição de energia elétrica para grupos de agricultores interessados. O incentivo governamental vinha na forma de apoio técnico e financiamento com juros baixos e prazos de 30 anos (TEIXEIRA, 1988). Logo surgiram centenas de cooperativas, espalhadas por todo o território dos EUA. Estima-se que, em fins da década de 40, quase toda a área rural americana estava eletrificada. Ainda hoje, o sistema cooperativista de eletricidade americano tem um porte considerável, comparando-se em dimensões a todo o sistema elétrico brasileiro.

Segundo a NRECA, associação das cooperativas americanas, o sistema cooperativista dos EUA é composto de 865 cooperativas de distribuição de energia e 65 de geração e transmissão. Estas cooperativas servem (NRECA, 2003):

- 36 milhões de pessoas em 47 estados;

- 15 milhões de estabelecimentos comerciais, casas, escolas, igrejas, fazendas, sistemas de irrigação e outros consumidores em 2.500 dos 3.128 municípios americanos;

- $\quad 12 \%$ da população total dos EUA.

Outros dados relevantes do conjunto de cooperativas americanas são: 
- Faturamento total de 76 bilhões de dólares anuais.

- Propriedade de 3,7 milhões de quilômetros (2,3 milhões de milhas) de redes de distribuição, equivalente a $43 \%$ do total das redes e cobrindo três quartos do território.

- Venda de $10 \%$ de toda a energia consumida nos EUA.

- Geração de $5 \%$ do total de eletricidade.

- $\quad 60.000$ empregados no total.

- $\quad 11.500$ consumidores por cooperativa, na média.

O caráter rural das linhas é evidenciado na comparação com os outros dois tipos de empresas existentes, as particulares (investor-owned) e as públicas/municipais (publicily owned):

Tabela 2.1 - Dados dos Sistemas de Distribuição nos EUA

\begin{tabular}{|l|c|c|}
\hline \multicolumn{1}{|c|}{ Tipo de Empresa } & $\begin{array}{c}\text { Consumidor por } \\
\text { quilômetro de linha } \\
\text { (cons/km) }\end{array}$ & $\begin{array}{c}\text { Faturamento por } \\
\text { quilômetro de linha } \\
\text { (US\$/km) }\end{array}$ \\
\hline Cooperativas & 10,62 & 13.676 \\
\hline Particulares & 54,71 & 94.931 \\
\hline Públicas & 70,80 & 15.848 \\
\hline
\end{tabular}

Fonte: NRECA, 2003, com ajustes do autor.

A experiência americana, bem como em alguns países da Europa, fez surgir cooperativas de eletrificação rural em toda a América Latina, inclusive no Brasil. Antes, ainda na década de 20 , já haviam sido realizadas as primeiras tentativas de se organizar a eletrificação por cooperativas:

"A eletrificação chegou ao meio rural brasileiro atendendo a uma demanda do imigrante europeu, na década de 20. As comunidades étnicas do interior do sul do país tentaram organizar as primeiras cooperativas de eletrificação rural. Possivelmente proprietários agrícolas, do estado de São Paulo, tenham sido os primeiros atendidos, buscando infra-estrutura, água potável, luz, escolas e mecanização da atividade rural. A primeira cooperativa só foi

\footnotetext{
${ }^{2}$ Hoje Rural Utilities Service
} 
fundada vinte anos depois, em 1941. Foi em Quatro Irmãos, Rio Grande do Sul, estado onde essa prática se expandiu e é estável até hoje." (RIBEIRO, 1993, pg. 29ss)

Segundo TENDRIH (1990) “as primeiras iniciativas de discussão para solucionar o problema da eletrificação rural no país aconteceram na segunda metade da década de 50”. Em 1959 surge no estado de São Paulo o SEER - Serviço Especial de Eletrificação Rural e em 1962 a ERMIG - Eletrificação Rural de Minas Gerais, subsidiária da CEMIG. Ambas as iniciativas se inspiraram no modelo norteamericano, com preocupações de redução de custos e organização dos consumidores em forma de cooperativas (RIBEIRO, 1993).

TENDRIH (1990), aponta uma característica da eletrificação rural brasileira neste período: a expansão realizada através da formação de cooperativas com o incentivo do Estado e até das concessionárias. Ora, porque não a realização direta de investimentos pelas próprias concessionárias estatais que estavam se constituindo? A razão é a facilidade com que esse mecanismo permitia obter recursos externos, já que

"os financiadores estrangeiros consideravam essa forma (cooperativismo) como a mais adequada à eletrificação rural. Este seria, aliás, mais um caso de tentativa de transposição de experiências bem sucedidas em outros países para o Brasil." (TENDRIH, 1990, pg. 67)

Aqui se deve marcar uma diferenciação, que perdura até hoje, entre as cooperativas do Sul/Sudeste e do Nordeste. Enquanto as do Sul/Sudeste nasceram também marcadas por um esforço comunitário e associativo regional, as do Nordeste nasceram principalmente por

"estímulo das próprias concessionárias, que utilizaram as cooperativas como veículos para captação de recursos 'marcados', a baixo custo, e dirigidos à expansão da eletrificação no campo." (COOPERS \& LYBRAND, 1997, pg. 13)

Em 1964, o Estatuto da Terra estabelecia a estrutura de cooperativas como a principal forma de promoção da eletrificação rural, instituindo também incentivos como isenção do empréstimo compulsório então vigente, prioridade de financiamento e a possibilidade de receberem auxílios do poder público (TENDRIH, 1990). Em 1970 foi lançado o I PNER - Plano Nacional de Eletrificação Rural, com 
recursos do Banco Interamericano de Desenvolvimento - BID, que exigia que o tomador fosse uma cooperativa de eletrificação rural. Em São Paulo, o governo paulista implantava, através do Departamento de Águas e Energia Elétrica - DAEE, novas cooperativas com esses recursos. Em 1978 foi lançado o II PNER. Ao mesmo tempo, a Eletrobrás desenvolvia programas próprios, financiando as concessionárias.

RIBEIRO (1993) aponta os problemas dessa época:

"Havia, pois, a política de eletrificação rural do Ministério de Minas e Energia, imposta pela Eletrobrás ao setor elétrico (...) movimentando recursos do próprio e poderoso setor.

Havia, também, a política de eletrificação rural do Ministério da Agricultura, (...) através do II PNER, aplicando recursos captados junto ao BID.

Aquela a das concessionárias, Esta, a política das cooperativas.

A eletrificação rural do Brasil tornou-se uma grande confusão institucional. Estabeleceu-se uma dualidade de competências e programas. Como as concessionárias estaduais acabam manipulando o poder concedente de maneira peculiar e circunstâncias próprias, a distribuição rural tornou-se palco de conflitos, divergências e luta pelo poder entre as diferentes concessionárias e as cooperativas de eletrificação rural." (RIBEIRO, 1993, pg. 36ss)

Na década de 80, por conta de toda essa movimentação, consolida-se um sistema cooperativista de eletrificação rural, e começam a aflorar os conflitos entre cooperativas e concessionárias. Em 1985, o Departamento Nacional de Águas e Energia Elétrica - DNAEE - aponta, em um documento, os principais problemas (RIBEIRO, 1993):

- indefinição das áreas de atuação dos agentes (concessionárias e cooperativas) e do mercado possível de ser atendido;

- custos de fornecimento de energia e implantação de redes díspares, fazendo com que o consumidor da cooperativa pague mais pela energia que o seu vizinho da concessionária, provocando também uma rejeição ao sistema de cooperativas. 
No início da década de 90, as cooperativas de eletrificação rural brasileiras formavam um sistema organizado em duas grandes confederações, existentes até hoje: a Infracoop (Confederação Nacional das Cooperativas de Infra-Estrutura), que congregava as cooperativas do Sul/Sudeste, e a Conbrac (Confederação Brasileira das Cooperativas de Energia, Telefonia e Desenvolvimento Rural), reunindo as cooperativas do Nordeste. Nos estados, as cooperativas de eletrificação rural se organizam em federações, como a Fecoeresp (Federação das Cooperativas de Eletrificação Rural do estado de São Paulo), Fecoerpa (Paraná), Fecoergs (Rio Grande do Sul), Fecoerusc (Santa Catarina), Fecoerpe (Pernambuco), entre outras.

\subsection{A regulação das cooperativas: do Código de Águas à Constituição de 1988}

A primeira menção que um texto legal específico do setor elétrico faz às cooperativas de eletrificação rural é o Art. 154, inciso III do Decreto 41.019/57, que regulamenta o Código de Águas, como agentes atuantes no processo de expansão dos sistemas elétricos. A menção a suas atividades, porém, viria com o Decreto 1.033, de 22/05/62, que é o primeiro marco regulatório específico para as cooperativas de eletrificação rural.

\subsubsection{O Decreto 1.033/62}

O Decreto 1.033/62 veio realizar uma ação comum no Direito: transformar uma situação de fato em uma situação de direito. No caso, trazer para a regulamentação do setor elétrico um agente existente, a cooperativa de eletrificação rural, e dar-lhe um caráter legal: um agente do setor elétrico enquadrado como permissionário de distribuição ou concessionário de uso exclusivo de energia elétrica.

A finalidade do Decreto era permitir com que as cooperativas existentes se registrassem no Ministério de Minas e Energia sob uma das duas condições (Art. $1^{\circ}$ ), permitir o requerimento para produzir energia elétrica (Art. $4^{\circ}$ ) e, mais importante, 
que ficassem sujeitas aos direitos e deveres impostos em lei para as duas categorias jurídicas $\left(\right.$ Art. $\left.5^{\circ}\right)$.

SOUTO; LOUREIRO (1999) afirmam que:

"A partir desse diploma, a atividade de eletrificação rural passou a ser realizada sob dupla configuração, serviço público, quando prestada pelas concessionárias, e 'uso exclusivo', quando realizada pelo consumidor, em seu próprio interesse (e aqui insere-se a cooperativa)." (SOUTO; LOUREIRO, 1999, pg. 69)

Os mesmos autores detêm-se na análise do Decreto e apontam as suas contradições:

“ (...) o fornecimento de energia da cooperativa para o associado, no esquema (mantido) do Decreto $n^{\circ} 1.033 / 62$, caracteriza 'uso exclusivo' ${ }^{3}$ de energia, e não serviço público. Na medida em que, porém, tal energia é fornecida pela concessionária, constitui serviço público o atendimento, por esta - através da cooperativa - do consumidor final." (SOUTO; LOUREIRO, 1999, pg. 71)

Neste Decreto, então, a origem de uma contradição que perdura até hoje: a prestação de um serviço público por um agente de uso exclusivo.

Mas, então, porque essa contradição não foi logo notada, sendo, ao contrário, incentivada pelo poder concedente? Além dos fartos recursos financeiros então disponíveis para criação de cooperativas, SOUTO; LOUREIRO (1999) apontam outras razões:

"A idéia básica que motivou o largo uso da forma cooperativada está ligada à pouca rentabilidade que o serviço de eletrificação rural proporcionava. Como este tipo de sociedade - cooperativa - não tem finalidade de lucro, mas de auxílio mútuo ente os sócios e está aberto a todos os que necessitam do serviço, a constituição das cooperativas fazia-se no exclusivo interesse dos consumidores (sócios) de energia no meio rural. A par disso, o tipo societário escolhido e seu ato característico (ato cooperativo) sempre gozaram de incentivos econômicos de toda a ordem, específicos. Em síntese, o modelo 'cooperativa' conjugava os beneficios dispensados à atividade com aqueles próprios de sua natureza." (SOUTO; LOUREIRO, 1999, pg. 71ss)

\footnotetext{
3"Uso exclusivo não se trata de uma comercialização de energia, não se caracterizando, por conseguinte, prestação de serviços públicos. Os associados, reunindo seus recursos, constroem as redes e linhas para seu próprio uso" (BUENO, apud SOUTO; LOUREIRO, 1999, pg.69)
} 
Num momento em que o setor elétrico se consolidava, rumando de um modelo privado para um estatal, onde o Estado fazia pesados investimentos na área (a Eletrobrás foi criada em 1962) visando prover o processo de industrialização de infraestrutura energética, parece conveniente que a expansão na área rural, sabidamente acessória a esse processo, se desse por intermédio de cooperativas. Ainda mais dentro de um contexto de incentivos internacionais e experiências bem sucedidas.

Essa expansão, contudo, nunca foi sinônimo de fomento à eletrificação rural como alternativa de ruptura com as concessionárias, como foi nos EUA. A esse respeito, SOUTO; LOUREIRO (1999), opinam que:

"Tratava-se, sobretudo, de uma solução de exceção, destinada a ser substituida no futuro." (SOUTO; LOUREIRO, 1999, pg. 72)

Parece que essa afirmação, se não era totalmente compartilhada na época, encontrava ecos dentro do setor. Assim, em 1968 é emitido outro Decreto, que veio a substituir o Decreto 1.033/62, definindo e limitando a atuação das cooperativas de eletrificação rural.

\subsubsection{O Decreto $62.655 / 68$}

O Decreto 62.655/68 pode ser considerado o marco principal na legislação da eletrificação rural e das cooperativas. Ele foi elaborado num contexto de um regime de exceção que, segundo uma visão centralizadora e autoritária, promoveu profundas mudanças no setor elétrico brasileiro.

Qual a sua motivação? Tudo leva a crer que, com a expansão do sistema de eletrificação rural por cooperativas, surgiam já os primeiros conflitos entre estas e as concessionárias. As empresas distribuidoras reclamavam de um agente que se implantava e, de certa maneira, competia por um mercado que, mesmo que elas não tivessem interesse em atender, no futuro poderia se mostrar rentável. O Decreto possuía, então, a intenção de delimitar, de modo mais preciso, a atuação das 
cooperativas. Para tanto, logo em seu Art. $1^{\circ}$, define com bastante precisão (até espantosa), o que é eletrificação rural:

“Art. $1^{\circ}$ - É considerada eletrificação rural a execução de serviços de transmissão e distribuição de energia elétrica destinada a consumidores localizados em áreas fora dos perímetros urbanos e suburbanos das sedes municipais e aglomerados populacionais com mais de 2.500 habitantes, e que se dediquem a atividades ligadas diretamente à exploração agropecuária, ou a consumidores localizados naquelas áreas, dedicando-se a quaisquer tipos de atividades porém com carga ligada de até $45 \mathrm{kVA}$."

Quanto às cooperativas, são tratadas no Art. $2^{\circ}$, de modo oblíquo, através do instrumento da permissão.

Art. $2^{\circ}$ - Depende de permissão federal, por ato do Ministro das Minas e Energia, a execução de obras de transmissão e distribuição de energia elétrica destinada ao uso privativo de consumidores rurais, individualmente ou associados.

O Art. $4^{\circ}$ define os requisitos para obtenção da permissão, tanto de pessoas físicas como jurídicas. Os principais são:

- Declaração do concessionário local concordando em fazer o suprimento ao requerente;

- Declaração de responsabilidade técnica pela manutenção e operação do sistema (podendo a concessionária supridora assumir essa responsabilidade);

- Cadastro de todos os consumidores beneficiados;

- Projeto elétrico de implantação das redes;

- Orçamento e descrição detalhada da obra e de seus objetivos.

O Art. $6^{\circ}$, ainda, obriga a comunicação de eventuais modificações e ampliações, para efeitos estatísticos.

Ora, percebe-se claramente que este Decreto limita e restringe bastante a atuação das cooperativas. Primeiro aos consumidores somente de eletrificação rural; 
depois não permitindo o estabelecimento de serviço público e exigindo um cadastro inicial dos beneficiários e a comunicação de cada nova ligação (ampliação).

O fomento à atuação das cooperativas se completa com a criação, em 1970, através do Decreto 67.052, do FUER (Fundo de Eletrificação Rural das Cooperativas) e GEER (Grupo Executivo de Eletrificação Rural das Cooperativas), que eram encarregados de coordenar o Programa Nacional de Eletrificação Rural, programa este que foi definido de forma mais ampla no Decreto 79.898/77.

Este Decreto, que previa a eletrificação rural por meio do incentivo à formação de cooperativas, supervisionado pelo Ministério da Agricultura, falava em seu Art. $2^{\circ}$ :

"Art. 2". A programação no artigo $1^{\circ}$ (Programa Nacional de Eletrificação Rural) deverá assumir:

I - Caráter de complementação, entre a ação nacional desenvolvida pelo conjunto das empresas concessionárias, sob a coordenação da ELETROBRÁS e o esforço realizado em certas áreas, pelas cooperativas de eletrificação rural, dentro do Programa supervisionado pelo Ministério da Agricultura.

II - Sentido dinâmico, a fim de permitir que à medida que a atuação das empresas concessionárias se amplie, naturalmente, de áreas urbanas para as áreas rurais, a atuação das cooperativas se concentre nas regiões menos atendidas."

De certa forma, o conjunto narrativo formado por estes decretos define claramente o campo de atuação das cooperativas, devidamente tutelados pelo poder público e pelas concessionárias. A intenção seria o fomento a cooperativas que, à medida que tivessem o mercado expandido, fossem absorvidas pelas concessionárias, visto que sua atuação estava restrita aos consumidores definidos no Art. $1^{\circ}$ do Decreto 62.655/68. Uma situação que é assim resumida por BUENO, apud SOUTO; LOUREIRO (1999):

“A cooperativa (...) forma inequivocamente um sistema bastante razoável, porquanto permite a congregação dos esforços, sem atritos com o esquema do serviço público. Isto, em razão da indesviável vinculação das cooperativas às concessionárias, em uma engrenagem em que as últimas tutelando as primeiras, serão sempre o ponto inicial e básico. 
Então, evitando-se o complexo problema da existência de concorrência na área, como se dá nos Estados Unidos, permanecendo sempre com as concessionárias o controle dos planejamentos e projetos, alcançando-se inevitavelmente melhores resultados." (BUENO, apud SOUTO; LOUREIRO, 1999, pg. 79)

SOUTO; LOUREIRO, 1999, sustentam que esta era a situação que, pela legislação, o sistema de cooperativismo de eletrificação rural deveria sustentar. De fato, analisando-se friamente os marcos legais, parece ser esta realmente a intenção do poder concedente do serviço de energia elétrica, a despeito da série de incentivos fornecidos às cooperativas de eletrificação rural. Não foi isso, porém, o que aconteceu, em virtude da clara tensão existente entre a política do setor elétrico, que buscava limitar a atuação das cooperativas de eletrificação rural, e a própria atuação destas, respaldadas pelo poder político da Agricultura.

\subsubsection{A crise da década de 80}

Viu-se que, em conjunto com a legislação, o Estado promoveu vários incentivos para a expansão das cooperativas, principalmente entre fins da década de 60 e começo da década de 80 . A quase totalidade das cooperativas hoje existente teve sua criação e expansão nesse período.

Os marcos normativos citados se prestaram à formação de cooperativas segundo duas visões.

Na primeira, e que foi basicamente implantada no Nordeste, as cooperativas eram criadas pelas próprias concessionárias, visando o acesso ao financiamento do BID. Geralmente, nessas cooperativas, a rede de média tensão pertence às concessionárias, e as cooperativas detêm a propriedade e são responsáveis pelas redes de baixa tensão, a medição e o relacionamento com o consumidor/cooperado. É um modelo que ainda hoje vigora em concessionárias daquela região.

Na segunda visão, foram criadas cooperativas que possuíam a propriedade e a gestão de toda a rede, de média e baixa tensão. Este é o modelo que foi implantado no Sudeste e no Sul. Em grande parte dos estados (Minas Gerais, São Paulo, Paraná, 
Santa Catarina, Rio Grande do Sul), houve o apoio decisivo do poder estadual na formação de cooperativas de eletrificação rural.

Em São Paulo, particularmente, o DAEE tinha, nas décadas de 60 e 70, um programa bastante agressivo de formação de cooperativas. Existiam equipes de organização, projeto e implantação, constituindo verdadeiras "fábricas" de cooperativas, que se espalhavam por toda São Paulo. Chegou-se a mobilizar um grande contingente de engenheiros, técnicos e advogados, exclusivamente dedicados à eletrificação rural que, na época, era sinônimo de implantação de cooperativas.

Esta época pode ser considerada os "anos dourados" do cooperativismo da eletrificação rural.

As cooperativas implantadas logo desenvolveram um mercado que passou a se expandir. O crescimento natural, tanto do campo como das cidades, propiciou oportunidades para que elas atendessem consumidores que o Decreto 62.655/68 não permitia.

O órgão fiscalizador, na época, era o DNAEE, autarquia federal que não possuía estrutura nenhuma para efetuar esse trabalho. $\mathrm{Na}$ prática, eram as concessionárias distribuidoras que poderiam “executar” esse papel.

Ai vem uma nova contradição. A despeito de até terem, em raras vezes, a intenção de frear a expansão das cooperativas, elas não o fizeram pois, como estatais de propriedade estadual, em sua maioria, não poderiam se opor a uma política incentivada pelo seu próprio controlador. Na prática, as cooperativas se expandiam conforme o mercado de cada uma exigia, sob a conivência das concessionárias e do poder concedente, fazendo dos dispositivos legais letra quase morta.

Essa conivência estava longe de ser desinteressada. O mercado rural nunca foi interessante para as distribuidoras e, mesmo que elas tivessem programas próprios de eletrificação rural, bancados pelo Estado, a expansão das cooperativas era conveniente, enquanto não abordassem mercados mais rentáveis. 
$\mathrm{Na}$ década de 80 , começaram a refluir os incentivos às cooperativas. $\mathrm{O}$ modelo não foi suficientemente capaz de eletrificar toda a zona rural, o Estado passou a viver com uma crise de investimentos e as concessionárias, após sua consolidação como empresas, passaram a implantar diretamente seus próprios programas de eletrificação rural, mesmo porque politicamente era mais vantajoso. Em 1989, extingue-se o GEER e, em 1990, o FUER.

Sem a tutela do Estado, e vítimas, da mesma forma que as concessionárias, de uma política de contenção tarifária utilizada para minimizar o processo inflacionário, muitas cooperativas acabaram se inviabilizando. Em Minas Gerais, quase todas foram encampadas pela CEMIG, tradicionalmente uma concessionária agressiva na área da eletrificação rural, assim como a COPEL, que encampou a maioria das cooperativas do Paraná. As duas concessionárias são dois dos melhores exemplos de bom atendimento da eletrificação rural no Brasil.

Em São Paulo, das 33 cooperativas criadas, restaram dezessete. O DAEE desmobilizou a sua equipe de eletrificação rural, restando um único funcionário, que hoje integra a Fecoeresp e a representa junto ao poder público. Ainda assim, a cada troca de governo, as cooperativas de São Paulo vão em romaria ao gabinete do governador manifestar o seu apoio, e pedir a permanência do funcionário.

Mesmo com essa desmobilização, permaneceram ainda ativas um grande número de cooperativas de eletrificação rural no Brasil, transitando por um espaço jurídico meio nebuloso. Em geral, prestando um serviço público, em uma área de atuação mais ou menos definida, com a concessionária estatal fornecendo energia com desconto e pronta para assumir o serviço caso houvesse problemas na cooperativa.

\subsection{0 tradicional conceito de permissionária}

O Decreto 62.655/68, em seu Art. $2^{\circ}$, define como permissão federal a execução de obras de transmissão e distribuição de energia elétrica destinada ao uso privativo de consumidores rurais, individualmente ou associados. 
Cabe aqui uma observação: a permissão, como definido neste decreto, não constitui delegação de "Poder Público", ou seja, não permite que o seu detentor realize tarefas típicas do Poder Concedente, como comercializar energia, cobrar tarifas e estabelecer contratos com consumidores. A permissão, neste sentido, autorizava apenas a execução de obras para "uso privativo", termo que restringe o uso apenas aos interesses exclusivos dos requerentes.

Neste ponto, observa-se uma nítida confusão entre os termos permissão e autorização, então existente na legislação. SOUTO; LOUREIRO (1999), observam que:

"Quando a função, como no caso, não configurava serviço público, o título era a autorização (ou permissão), como tal prevista em diversos dispositivos do Dec. $n^{\circ} 41.019 / 57$, em particular, arts. 66 e 110 e segs. Esses dispositivos já utilizavam vocábulos autorização e permissão como intercambiáveis.

Autorização e permissão eram vocábulos sinônimos que significavam, em resumo, aquiescência da União com o uso próprio. Este título já era à época, muito diverso da concessão, utilizada para outorgar ao particular o direitodever de prestar serviço público." (SOUTO; LOUREIRO, 1999, pg. 75ss)

A Constituição Federal de 1988 deu forma aos instrumentos da concessão, permissão e autorização, o que é tema de uma discussão mais à frente.

Todavia, nos últimos trinta anos e até há bem pouco tempo atrás, o termo cooperativa de eletrificação rural era considerado, no linguajar comum, sinônimo de permissionária de serviço elétrico. "Cooperativa" ou "Permissionária" eram tidos por mesma coisa.

Havia uma certa cisma no setor com as cooperativas. Eram vistas como entes em extinção, coisas da antiguidade atravancando o progresso da concessionária, obsoletas, mal administrados, arcaicos. Inviáveis.

Por seu lado, as cooperativas davam-se o mérito de serem agentes da expansão da eletrificação rural, sensíveis à condição social do povo da roça.

Nem lá nem cá. 


\section{CAPÍTULO 3 - DA NOVA REPÚBLICA AO ESTADO NEOLIBERAL}

\subsection{A estagnação da eletrificação rural}

Os organismos multilaterais foram os grandes patrocinadores de investimentos em grandes obras de infra-estrutura realizadas pelo Estado a partir do Pós-Guerra e deixaram grandes marcas na eletrificação rural no Brasil, principalmente no Paraná e em Minas Gerais. Ainda hoje é possível detectar que tais regiões possuem uma maneira diferente de olhar para o campo sem luz. Têm preocupações com a utilização de metodologias de simplificação de circuitos de distribuição com o fim de construir redes baratas, preocupações com o acesso de proprietários rurais de baixa renda, com esquemas de financiamento adequado, com o uso final da energia, com a utilização de sistemas solares fotovoltaicos domiciliares. Essa época de grandes programas deixou no Paraná um sistema exemplar de equivalência em produto, sendo que a concessionária, a partir da carga solicitada e da distância à rede dava um preço em sacas de milho a longo prazo para o solicitante. Em Minas, ainda funciona uma fazenda energética que visa o uso eficiente da eletricidade na agricultura, mantida pela concessionária estadual.

Mas a festa acabou, o povo sumiu, a luz deixou de ir acendendo lugares escuros, ou, no dizer do poeta maior de Minas, “a luz apagou...”. Não houve mais os dólares do Banco Mundial e do Banco Interamericano de Desenvolvimento para a Nova República fazer eletrificação rural, ou qualquer outra obra elétrica do Estado. "A luz apagou" no próprio governo federal, que ficou sem qualquer sala para abrigar uma equipe de interessados no problema. Realmente, "o povo sumiu...".

Em 1989, o Comitê de Distribuição - Codi - e em 1990 o Comitê de Controle de Operações do Norte e Nordeste - CCON - reuniram as concessionárias brasileiras, quase todas, para uma enquete sobre a situação da eletrificação rural, fazendo a todas elas as mesmas quase cem perguntas. Havia cinco perguntas que se relacionavam com as cooperativas de eletrificação rural. 
A Escola Politécnica tentou ter acesso aos resultados do trabalho, mas houve censura da administração do Codi, e os pesquisadores não puderam saber como era a realidade do setor de distribuição de energia elétrica de seu país.

CORREIA (1992), dois anos depois portanto, conseguiu ter acesso a essas informações através de uma concessionária. Sua dissertação de mestrado, apresentada à Escola Politécnica, exibiu uma análise crítica desses dados. Vale a pena atentar ao tom das perguntas, é uma imagem das cooperativas no ano de 1989.

Indagava-se: elas existem? Atrapalham o desempenho dos circuitos da concessionária? Há uma política de incorporação das cooperativas de eletrificação rural? (CORREIA, 1992). A pouca simpatia causada pelas cooperativas é evidente. Ressalte-se a resposta da Cemig: já havia incorporado 34 cooperativas, mas ainda restavam 4 por incorporar. A Celg também pretendia incorporar as cooperativas de sua área, e a Energipe tencionava excluí-las de qualquer programa novo de eletrificação rural.

A perplexidade do setor elétrico brasileiro dos anos 90 atingiu as cooperativas. Grandes dificuldades financeiras, redução drástica de investimentos, pouca vontade de fazer eletrificação rural, preços e tarifas altos, cobrança de importâncias indevidas pretensamente justificada pelo aspecto de serem cooperativas, nada de expansão. Tais coisas seriam até esperáveis, pois toda a infraestrutura brasileira estava na mesma toada. Mas, algumas poucas iniciativas que houve, de programas de eletrificação rurais localizados, com financiamento do Banco Nacional de Desenvolvimento Econômico e Social - BNDES - tiveram resultados surprendentes. No Rio Grande do Sul, ROSA et al. (1993) avaliam que os consumidores das cooperativas tiveram os custos por ligação mais caros do Programa Proluz, que atingiu diferentes regiões do estado.

A perplexidade maior de quem observou a atitude das cooperativas de eletrificação rural na década de 90 fica por conta do estado de São Paulo. Também com verbas originárias do BNDES, repassadas pelo Banco Nossa Caixa, banco estatal, com a coordenação da Secretaria de Energia e participação de outras secretarias, como a de Agricultura, da Ciência, Tecnologia e Desenvolvimento 
Econômico, e do Planejamento, e com acompanhamento da Escola Politécnica da Universidade de São Paulo, foi implantado o Programa "Luz da Terra". Tinha finalidade marcadamente social, e, entre outras características, impunha a obrigatoriedade de não se excluir qualquer cidadão do atendimento elétrico (PELEGRINI, 1998).

Ressalte-se o pioneirismo: pela primeira vez no Brasil, sem respaldo na literatura que informasse qualquer semelhante experiência no mundo, muito antes de ser criado o termo "universalização do atendimento", em São Paulo, por imposição do BNDES, representado pelo PEA/EPUSP, foi planejada uma política de eletrificação rural com base no atendimento universal, consubstanciada em decreto estadual. A perplexidade fica por conta das cooperativas de eletrificação rural de São Paulo, com exceção de uma, terem se omitido de trabalhar para ligar novas cargas, deixando no escuro no final do século XX milhares de famílias cujo atendimento não lhes daria despesas. Mas daria trabalho. Omitiram-se de ter que trabalhar em programa de eletrificação rural por não acharem que teriam grandes vantagens econômicas em atender o pobre rural, perfil dominante do mercado por ligar.

\subsection{Preocupações na transição}

Se as cooperativas de eletrificação rural de São Paulo não se interessaram em participar de programa de atendimento de público pobre, elas tiveram uma década de outras grandes preocupações.

Primeiro, foram se deixando ficar à margem das decisões do setor elétrico. Deram apoio político a Collor, de modo geral. Tiveram, nos primórdios da transformação do estado brasileiro em estado neoliberal, o empenho do Ministro da Agricultura, em 1990, no esboço de um grande programa de eletrificação rural destinados a elas, algo em torno de 3,2 bilhões de dólares para um programa que previa atendimento a um milhão de novos consumidores em todo o Brasil, com carga média de $7 \mathrm{kVA}$, a custo médio de 3,2 mil dólares. Antes que se definissem as fontes de financiamento o governo caiu, os planos também. 
Depois, com a discussão da reforma geral do estado. Se, por um lado, as classes conservadoras davam o maior apoio ao intuito liberalizante, por outro lado, o Plano Real foi cruel com a agricultura. No caso específico, foi ficando patente uma contradição: um dos mais festejados avanços do neoliberalismo foi vender as concessionárias de distribuição de energia elétrica. Feita a toque de e para fazer caixa, as privatizações das elétricas anteciparam-se à elaboração do arcabouço regulatório. Muita coisa foi ficando para trás, falava-se em transitório, depois se falava em "trocar o pneu com o carro em movimento", depois se falava em salvar a lavoura com o gás natural, depois se falava que ia faltar energia, nunca se falava da regulação das cooperativas.

A eletrificação rural foi um tema quase inexistente no Brasil dos 90. Fora o BNDES, nenhuma outra instituição federal se interessou por qualquer iniciativa. Se nos anos 80 a média anual de atendimento foi de 1,2 \% das necessidades, nos anos de privatização a coisa ficou pior. Com a nuvem negra que se formava no horizonte, com as perspectivas de uma degola nunca antes imaginada no emprego do funcionário de estatal elétrica, quem seria o maluco de pôr a cabeça à exposição para iniciativas que não eram bem vistas nem pelos próprios funcionários, como investimento em mercado pobre e disperso da zona rural?

No final da década foi lançado o maior programa de eletrificação rural do Brasil, o Programa "Luz no Campo", conduzido pela Eletrobrás, com empréstimos às concessionárias a partir de fontes do setor elétrico: a Reserva Global de Reversão RGR. Previa-se a participação das cooperativas, porém só em 2002 foi votada uma lei para permitir que pudessem ter acesso a esse fundo, restrito às concessionárias até então. Assim, cooperativas ficaram de fora da eletrificação de novas cargas durante os anos 90, salvo situações pontuais.

O Programa "Luz no Campo" reforçou a marginalização das cooperativas de eletrificação rural.

As cooperativas tinham a concessionária como adversárias existenciais. Eram do estado, e já eram adversárias ferozes. Vendidas para a banca internacional, 
projeto simpático aos conservadores, quem viria a ser o proprietário encarnando o novo inimigo mortal?

O fato é que as cooperativas se organizaram para acompanhar esse movimento. Organizaram sua gestão, foram atrás de apoio jurídico, modernizaram seus centros operacionais de controle do sistema elétrico, aprimoraram o atendimento aos consumidores, muito coisa mudou dentro delas. Souberam por suas lideranças como acompanhar o processo e tais lideranças passaram a ter uma atuação nacional muito mais presente. Lideranças modernas, acompanharam o debate nacional. Há quem acredite que, em alguns momentos, tais lideranças pautaram o debate sobre a regulação e a regulamentação das cooperativas de eletrificação rural.

\subsection{Tempos de reforma}

Os cinco últimos anos do final do século $\mathrm{XX}$ trouxeram duas fases absolutamente distintas e até opostas para a eletrificação rural. Opostas pela existência de uma tensão muito nítida entre as duas, tensão até que assumida por um de seus pólos. As cooperativas tiveram a mesma atitude perante as duas fases.

O setor elétrico envolveu-se com a iminência da reforma do Estado. Seus movimentos eram ou no sentido da reforma neoliberal em correria deslumbrada, ou no sentido de fazer a ela resistência, nem heróica, muito menos eficaz. Se nos quinze anos anteriores a eletrificação rural foi se apagando, ela se apagou de vez. Tudo parou, ficaram apenas os programas do BNDES em São Paulo e a segunda fase do programa do Rio Grande do Sul, alguma coisa pontual em outros estados, principalmente em Pernambuco.

O Departamento de Engenharia de Energia e Automação Elétricas da Escola Politécnica da Universidade de São Paulo manteve um grupo de estudos fazendo pesquisa sobre políticas de eletrificação rural, prestando consultoria ao BNDES e à Secretaria de Energia de São Paulo. O grupo participou ativamente do debate publicando trabalhos relativos ao tema da eletrificação rural, cooperativas e universalização do atendimento (JUCÁ et al., 2001; PAZZINI et al., 2001; 
PELEGRINI et al, 2001; RIBEIRO et al., 2001a; RIBEIRO et al., 2001b; RIBEIRO et al., 2001c; RIBEIRO et al., 2001d; ARIMURA et al., 2003; GALVÃO et al., 2003; PAZZINI et al., 2003; PELEGRINI et al., 2003; RIBEIRO et. al, 2003).

Tinha uma dificuldade enorme de encontrar interlocutores. Até mesmo no campo acadêmico: o neoliberalismo fez da eletrificação rural sinônimo de eletrificação rural fotovoltaica. A única voz que ainda se ouvia era a da pressão dos fornecedores internacionais de tecnologia, vendedores agressivos. Pareciam treinados para vender gelo no pólo norte ao querer vender energia renovável para substituir a "porca e esfumaçante energia da tomada", sem se darem conta de que o sistema central de energia elétrica no Brasil é também renovável, da chuva. Os estudiosos deste campo de inovação tecnológica acabavam por ficar atrapalhados pela picaretagem mercantil, já que seus potenciais interlocutores seriam engenheiros eletricistas tradicionalmente avessos à eletrificação rural, e, no Brasil, ideologicamente defensores da base hídrica, cheios de razão, cheios de experiências de sucesso, e que nem deram bola para os gringos vendedores de fotovoltaicos. Resultou em aversão a essa tecnologia em muitas áreas de onde se esperaria e onde se buscava apoio, principalmente no governo federal; resultou um formidável atraso em situações em que a solução solar fotovoltaica é incontestavelmente a opção correta! Também, os engenheiros estavam se preparando para a privatização, falar de mercado não lucrativo era absolutamente "out".

O Ministério de Minas e Energia publicou, em 1999, que havia cinco milhões de domicílios rurais sem luz. No Senado Federal se dizia que a população sem luz elétrica no Brasil era do tamanho da população da Argentina. Havia outros órgãos que diziam que a cifra era exagerada, era apenas a metade desse número. Algo como a população total da Argentina de fora da Grande Buenos Aires!

O que se chamou de primeira fase da eletrificação rural no cenário do estado liberal, era essa fase escura, arrogante em seus propósitos e descuidada da população mais sofrida do Brasil, o pobre rural. O descaso com uma parcela de muitos milhões de brasileiros que ficam fora do mercado de energia é, em si, uma tensa contradição com os propósitos do reformulador do Estado, que tem a ideologia do mercado, tudo 
por ampliar mercado. E, formalmente, dá como uma das razões e justificativas para seu açodamento em abrir a economia ao capital bancário internacional - antes mesmo de resolver conflitos regulatórios existentes e potenciais - a possibilidade de universalizar o atendimento.

O então ministro de Minas e Energia reconheceu a tensão, até como militante do Partido da Frente Liberal. Corajosamente, a despeito de quase todos no setor elétrico que torciam o nariz para o tema, afrontando grupos econômicos que lhe queriam impor outras prioridades, lançou o Programa "Luz no Campo", a "menina dos olhos do Ministro" no dizer irônico e contrariado do representante da Associação Brasileira dos Grandes Consumidores de Energia Elétrica. Previa atender em três anos um milhão, dos cinco necessários, de novos consumidores, como uma forma de compensação social, como o lado social das atividades de sua pasta que, na outra ponta, tinha conduzido a venda da maioria das concessionárias de distribuição estatais.

Em cerimônia em Recife, no encerramento da XVII Conferência Latinoamericana de Eletrificação Rural - XVII CLER - o ministro Rodolpho Tourinho lançou o Programa "Luz no Campo" fazendo várias referências explicitas a contribuições do Departamento de Engenharia de Energia e Automação Elétricas da Escola Politécnica na concepção do programa, principalmente, no estabelecimento de paradigmas sociais para a engenharia de distribuição rural, tidos por paradigmas inovadores.

O autor esteve presente à cerimônia. O Programa "Luz no Campo" terminou os seus três primeiros anos tendo ligado 600.000 consumidores a um custo médio de cerca de US\$ 1.000 por consumidor. As cooperativas de eletrificação rural não se afetaram nem com a primeira fase aqui referida - acompanharam a inação relativa à eletrificação rural - como não se afetaram com a segunda fase - continuaram inativas em programas de eletrificação rural, salvo uma ou outra, enquanto as concessionárias implementavam o maior programa já havido no Brasil. 
As cooperativas estiveram presentes à cerimônia em Recife. Em lugar de destaque, na mesa, ao lado do Ministro. Diziam-se participantes do debate sobre sua regulação, interlocutores do governo. Diziam-se preparadas para a regularização.

Diziam que queriam participar, no futuro, do programa de eletrificação rural. Diziam que se movimentavam para alterar alguns entraves legais.

Diziam que confiavam na mediação da agência reguladora. Diziam-se tranqüilas, confiantes no Governo. Na realidade, as cooperativas de eletrificação rural estavam ficando de fora do programa porque sua fonte financiadora, por lei, era restrita ao uso da concessionária. 


\section{CAPÍTULO 4 - AS COOPERATIVAS NO NOVO QUADRO}

\section{INSTITUCIONAL}

\subsection{Os serviços públicos na Constituição de 1988}

Antes da Constituição Federal de 1988, os serviços de energia elétrica eram basicamente regulamentados pelo Decreto 24.643/34 (Código de Águas) e centenas de atos regulamentares como portarias e decretos. As poucas leis disciplinavam apenas situações especiais, como a Usina de Itaipu (GIRARDI, 2000).

A Constituição Federal de 1988 trouxe uma importante modificação no regime de prestação de serviços públicos pelo Estado. O Art. 21, inciso XII, alínea b, institui os conceitos de autorização, permissão e concessão para os serviços de energia elétrica:

“Art. 21. Compete à União: (...)

XII - explorar, diretamente ou mediante autorização, concessão ou permissão: (...)

b) os serviços e instalações de energia elétrica e o aproveitamento energético dos cursos de água, em articulação com os Estados onde se situam os potenciais hidroenergéticos;"

O Art. 175 faz outra inovação: a obrigatoriedade de licitação para a outorga de concessão e permissão de todos os serviços públicos:

“Art. 175. Incumbe ao poder público, na forma da lei, diretamente ou sob regime de concessão ou permissão, sempre através de licitação, a prestação de serviços públicos.

Parágrafo único. A lei disporá sobre:

I - o regime das empresas concessionárias e permissionárias de serviços públicos, o caráter especial de seu contrato e de sua prorrogação, bem como as condições de caducidade, fiscalização e rescisão da concessão ou permissão;

II - os direitos dos usuários; 
III - política tarifária;

IV - a obrigação de manter serviço adequado."

Segundo GIRARDI (2000), a observância dessa condição (existência de licitação), trouxe a possibilidade de ruptura com o modelo estatal e consolidou o caminho para um novo modelo setorial com a possibilidade de inserção da figura do Produtor Independente de Energia.

Os dois artigos em conjunto definem, em linhas gerais, os princípios do serviço público de energia elétrica:

- $\quad$ É de responsabilidade da União.

- Pode ser prestado diretamente ou por meio dos instrumentos da autorização, permissão ou concessão (assim dispostos hierarquicamente, do mais precário para o menos).

- Neste caso (permissão ou concessão), devem ser objeto de licitação.

- Deve ser previsto, na regulamentação, os termos do contrato, os direitos dos usuários, a política tarifária e a obrigação de manter serviço adequado.

O Art. 175 permaneceu sem ser regulamentado durante um bom tempo. Somente em 1995 foi publicada a lei 8.987, conhecida como Lei de Concessões, no conjunto de dispositivos constantes do projeto de reforma do Estado e do projeto de reestruturação do setor elétrico brasileiro.

A lei 8.987 regulamentou, com maior precisão, os conceitos de concessão e permissão. Estes conceitos, em conjunto com o da autorização, são objeto de controvérsia entre os doutrinadores, tanto brasileiros como estrangeiros (GIRARDI, $2000)^{4}$.

\footnotetext{
${ }^{4}$ A esse respeito, GIRARDI, 2000, comenta "a controvérsia é própria do Direito, o qual não sendo uma ciência exata oferece sempre a possibilidade de entendimentos e definições não convergentes no tocante ao resultado final. Por isso, o uso do vocábulo concessão, em acepções mais amplas ou mais restritas, é motivo de dificuldade na fixação do seu conceito" (GIRARDI, 2000, pg.3)
} 
A concessão de serviço público pode ser definida como a delegação, a um particular ou a um ente público, da gestão ou execução de um serviço público, por sua conta e risco, mediante remuneração, via tarifa, pelos usuários. Ela é uma forma indireta de prestação de serviço público, onde, no seu ato, constam cláusulas que disciplinam a organização e funcionamento do serviço público e, no contrato, se assegura o seu equilíbrio econômico-financeiro. A lei 8.987 a define assim:

"Art. $2^{\circ}$

\section{(...)}

II - concessão de serviço público: a delegação de sua prestação, feita pelo poder concedente, mediante licitação, na modalidade de concorrência, à pessoa jurídica ou consórcio de empresas que demonstre capacidade para seu desempenho, por sua conta e risco e por prazo determinado."

A concessão é realizada sob a forma de um contrato de concessão que, segundo Hely Lopes Meirelles, apud GIRARDI (2000):

“(...) é um acordo administrativo (e não um ato unilateral da Administração), com vantagens e encargos recíprocos, no qual se fixam as condições de prestação do serviço, levando-se em consideração o interesse coletivo na sua obtenção e as condições pessoais de quem se propõe executá-lo por delegação do poder concedente. Sendo um contrato adminstrativo, como é, fica sujeito a todas as imposições da Administração, necessárias à formalização do ajuste, dentre as quais a autorização legal, a regulamentação e a concorrência. A lei apenas autoriza a concessão $e$ delimita a amplitude do contrato a ser firmado; o regulamento estabelece as condições de execução do serviço; o contrato consubstancia a transferência da execução do serviço, por delegação, ao concessionário, vencedor da concorrência." (MEIRELLES, apud GIRARDI, 2000, pg. 4ss)

A permissão de serviço público aproxima-se bastante do conceito de concessão, a menos de um certo "caráter precário". A lei 8.987 define assim permissão:

" "Art. $2^{\circ}$

\section{(...)}

IV - permissão de serviço público: a delegação, a título precário, mediante licitação da prestação de serviços públicos, feita pelo poder concedente à pessoa fisica ou jurídica que demonstre capacidade para seu desempenho, por sua conta e risco." 
Segundo COOPERS \& LYBRAND (1998) a permissão tem as seguintes características:

- Possui caráter precário e discricionário 5 .

- Admite condições e prazos para a exploração dos serviços, a fim de garantir rentabilidade e assegurar a recuperação do investimento do permissionário, visando a atrair a iniciativa privada na consecução dos serviços delegados.

- É formalizada através de um contrato de adesão ${ }^{6}$ (Art. 40 da lei 8.987), e sobre ela aplicam-se os mesmos dispositivos da concessão (Art. 40, parágrafo único da mesma lei). ${ }^{7}$

A distinção entre os dois instrumentos está definida em COOPERS \& LYBRAND (1998):

"Apesar de serem semelhantes em vários aspectos conceituais e legais, a concessão e a permissão são institutos diversos. Em geral, a concessão representa um regime mais estável, com maior segurança ao concessionário, por não estar revestida de caráter precário. No entanto, tal segurança se dá porque a delegação dos serviços é feita por contrato bilateral, gerando direitos e obrigações a ambas as partes, e envolvendo investimentos de grande monta. Segundo Marçal Justen Filho, a concessão é o instituto adequado a transferir a prestação do serviço público para a órbita privada, quando tal transferência importar atuação de médio e longo prazo, exigindo investimentos em bens reversíveis ao patrimônio público ${ }^{8}$. Já a permissão é mais propicia para delegações cujo prazo para a remuneração do

\footnotetext{
5 “(...) a permissão (é) um ato precário e discricionário, ou seja, rescindivel em qualquer tempo unilateralmente pela Administração se assim o interesse público recomendar."(BLANCHET, 1999, pg. 26)

${ }^{6}$ Embora formalizada por contrato, a permissão não perde o seu caráter precário.

${ }^{7}$ Entretanto, MEIRELLES, apud COOPERS \& LYBRAND (1998) sustenta que "tal aplicação somente será feita no que couber, uma vez que a concessão e permissão são figuras assemelhadas, mas distintas, não podendo ser equiparadas." (MEIRELLES, apud COOPERS \& LYBRAND, 1998, pg. 29)

${ }^{8}$ Todo bem que faz parte do serviço público de energia elétrica, por princípio, não pertence à concessionária, e sim à concessão. $\mathrm{O}$ ato de fincar um poste em área de domínio público e estender uma rede sobre ele já configura a prestação do serviço público, ilegal se não houver anuência do poder concedente, e sobre o qual o concessionário não tem posse dos bens utilizados. Ao se encerrar a concessão, todo o patrimônio do concessionário pertence então à União que, no entanto, deve restituir ao agente o valor econômico dos bens, calculado através de procedimentos contábeis definidos pelo poder concedente. $\mathrm{O}$ mesmo se aplica à permissão.
} 
investimento for curto. Não há transferência de patrimônio do particular à Administração 9 ." (COOPERS \& LYBRAND, 1998, pg. 30)

A autorização é matéria mais controversa. Apesar de citada no Art. 21 da Constituição, o Art. 175 não permite que seja utilizado este instrumento para delegação de serviços públicos.

A autorização é a outorga da Administração ao interessado para a prática de determinada atividade que, sem a mencionada anuência do poder público, seria proibida. $\mathrm{O}$ ato administrativo indica os direitos e obrigações do autorizado e também as hipóteses de revogação. Hely Lopes Meirelles, apud GIRARDI (2000), define a autorização como:

"é o ato administrativo discricionário e precário pelo qual o Poder Público torna possivel ao pretendente a realização de certa atividade, serviço, ou a utilização de determinados bens particulares ou públicos, de seu exclusivo ou predominante interesse, que a lei condiciona à aquiescência prévia da Administração, tais como o uso especial de bem público, o porte de arma, o trânsito por determinados locais, etc. Na autorização, embora o pretendente satisfaça as exigências administrativas, o poder público decide discricionariamente sobre a conveniência ou não do atendimento da pretensão do interessado ${ }^{10}$, ou da cessação do ato autorizado, diversamente do que ocorre com a licença e admissão, em que, satisfeitas as prescrições legais, fica a Administração obrigada a licenciar ou admitir" (MEIRELLES, apud Girardi, 2000, pg. 8)

E os serviços autorizados como:

"aqueles que o Poder Público, por ato unilateral, precário e discricionário, consente na sua execução por particular para atender a interesses coletivos instáveis $^{11}$ ou emergência transitória. (...) São serviços delegados e controlados pela Administração autorizante, normalmente sem regulamentação específica, e sujeitos, por indole, a constantes modificações do modo de sua prestação ao público e a supressão a qualquer momento, o que agrava a sua precariedade”. (MEIRELLES, apud COOPERS \& LYBRAND, 1998, pg. 28)

\footnotetext{
${ }^{9}$ Embora essa seja a interpretação do renomado doutrinador, não é esse o entendimento que a Aneel dá à permissão no processo de regularização, baseado na lei 8.987 . Na permissão também há reversibilidade dos bens afetos ao serviço.

10 "A solicitação do interessado, mero antecedente do ato, funciona como agente catalítico, não se incorporando à anuência estatal.” (GIRARDI, 2000, pg. 7).

${ }^{11}$ Que podem não ser permanentes.
} 
Segundo COOPERS \& LYBRAND (1998), a autorização tem as seguintes características:

- Não pressupõe a prestação de serviço público à comunidade, mas sim “autoconsumo" pelo particular das utilidades que produzir. Enseja a prestação de um serviço público por um particular em seu próprio benefício;

- poderá ser tarifada pela Administração, da mesma forma aplicada aos serviços de prestação ao público, dentro das possibilidades de medida para o oferecimento aos usuários;

- Em princípio, não exige licitação, mas a Administração poderá adotar um tipo de seleção para a escolha do melhor autorizatário;

- A sua contratação deriva de uma relação de Direito privado. No entanto, o Poder Público tem a prerrogativa de regulá-lo e fiscalizá-lo, aplicando sanções cabíveis em caso de faltas por parte do autorizatário, sob pena de ter cassada a autorização;

- Normalmente, a autorização é concedida por prazo determinado, podendo ser prorrogada;

À diferença da concessão e permissão, a autorização não implica obrigação contratual e, por conseguinte, não garante o equilíbrio econômico-financeiro do empreendimento autorizado.

\subsection{O serviço público concedido na reestruturação do setor elétrico}

A reestruturação do setor elétrico brasileiro, iniciada na década de 90 e seguindo principalmente os modelos liberais implantados na Inglaterra e no Chile, previu a mudança do papel do Estado de investidor para regulador (através das privatizações das empresas de energia) e também queria introduzir a competição na geração e comercialização de energia. A reestruturação do setor, além disso, pretendia trazer também a passagem de um ambiente estatal, sujeito às pressões 
políticas e tolerâncias inerentes ao Estado, para um ambiente privado com regulação pública, que pretendia propiciar garantias e isonomia aos consumidores.

O processo de reestruturação teve início em 1993, com a publicação da lei 8.631, que extinguiu a $\mathrm{CRC}^{12}$ e desequalizou as tarifas no território nacional. Com a eleição de Fernando Henrique Cardoso em 1994, a partir de 1995 aprofundou-se o processo de reforma, com o projeto RESEB (Reestruturação do Setor Elétrico Brasileiro), realizado pelo Ministério de Minas e Energia. Este projeto, que contou com consultoria especializada (consórcio liderado pela então Coopers \& Lybrand, hoje PriceWaterhouseCoopers), propôs, em seus relatórios, uma forma de reestruturação baseada na experiência britânica, no sentido de fortalecer mecanismos de mercado no setor, introduzindo a competição, a desverticalização das atividades das empresas, a privatização das estatais energéticas e a criação de um órgão regulador (Aneel), um operador independente do sistema (ONS) e um mercado livre de energia (MAE).

Para a consecução desse projeto, era necessário estabelecer mecanismos de competição dentro do setor. $\mathrm{O}$ instrumento da autorização, desse modo, entra como um dos principais para a geração de energia elétrica. Enquanto no regime anterior à reestruturação as usinas somente eram construídas sob o regime de concessão, e portanto com tarifa regulada pelo poder público, num novo ambiente onde se buscava a competição, o instrumento não era adequado a esse objetivo. Tornava-se necessário então, nas novas outorgas de geração e privatização das empresas geradoras, dotá-las de um instrumento jurídico que permitisse o livre ajuste de preços. Para esses casos, utilizou-se da autorização, para os chamados produtores independentes de energia (PIE).

$\mathrm{Na}$ transmissão e distribuição de energia elétrica, não havia essa diferenciação. O regime adequado, por se tratar de atividades onde há um monopólio natural, é o de concessão.

\footnotetext{
${ }^{12}$ A CRC (Conta de Resultados a Compensar) fazia uma contabilização das diferenças que cada concessionária tinha a receber ou a pagar, dentro de um ambiente onde a tarifa de energia elétrica era a mesma em todo o território nacional.
} 
O status jurídico das concessões existentes anterior à lei 8.987 era bastante confuso. Existiam casos de contratos de concessão em vigor, outros já expirados e até mesmo áreas sem concessão. Num ambiente onde todos os agentes eram estatais, não havia grande preocupação em realizar este ordenamento. Entretanto, um novo ambiente, onde se desejava a privatização das empresas, exigia um status jurídico adequado a esses contratos. Foi editada uma Medida Provisória (MP), no início de 1995, estabelecendo regras para o reagrupamento e prorrogação das concessões existentes, visando atingir, principalmente, as distribuidoras estatais.

Nas discussões do Congresso a respeito da MP, surgiu a questão das cooperativas de eletrificação rural. O status jurídico delas era como permissionária de serviço público, aptas a atuar apenas nas áreas rurais constantes dos atos permitivos, de acordo com o Decreto Federal 62.655/68, o que se assemelharia ao instrumento da autorização, na forma atual. Assim, como a MP tratava de questões referentes à concessão de áreas para as empresas distribuidoras de energia elétrica, foi incorporado a ela um artigo que definiu as regras para o poder concedente compatibilizar as áreas de atuação das concessionárias de distribuição e as cooperativas de eletrificação rural, bem como regularizar as cooperativas como permissionárias de distribuição de energia elétrica.

A menção da lei às cooperativas de eletrificação rural mostra a sua força política.

$\mathrm{O}$ artigo, não constante do texto original, foi notadamente fruto da atuação parlamentar da bancada cooperativista. A intenção inicial, apoiada pelas distribuidoras, era simplesmente promover a extinção das cooperativas de eletrificação rural, e a encampação de suas instalações (e mercado) pelas concessionárias supridoras. Para evitar essa situação, o embate político produziu o seguinte texto legal, convertido em artigo da Lei 9.074, resultante da MP convertida:

“Art. 23. Na prorrogação das atuais concessões para distribuição de energia elétrica, o poder concedente diligenciará no sentido de compatibilizar as áreas concedidas às empresas distribuidoras com as áreas de atuação de cooperativas de eletrificação rural, examinando suas situações de fato como 
prestadoras de serviço público, visando enquadrar as cooperativas como permissionárias de serviço público de energia elétrica.

Parágrafo único. Constatado, em processo administrativo, que a cooperativa exerce, em situação de fato ou com base em permissão anteriormente outorgada, atividade de comercialização de energia elétrica a público indistinto, localizado em sua área de atuação, é facultado ao poder concedente promover a regularização da permissão."

Tornou-se possível transformar uma área da cooperativa, uma situação de prestação de serviço público de fato, em uma situação de direito, como permissionária de energia elétrica. Movimento semelhante ao que, em 1962, havia acontecido por conta do Decreto 1.033. É claro que, agora, sob novo ordenamento jurídico, sob regras novas, adaptadas ao contexto atual.

O instrumento da permissão atual tem diferenças em relação ao anterior, dado pelo Decreto 62.655/68. Ele obriga à obediência dos dispositivos da Lei de Concessões, ou seja, a obrigação de se ter um contrato regendo a permissão, uma área de atuação definida, com exclusividade no serviço de distribuição, e tarifas e serviços regulados pelo Estado. É um status jurídico muito mais abrangente, com direitos e deveres estabelecidos quase como uma concessão. Essa repentina mudança de status, embora benéfica para a cooperativa e para seus consumidores/cooperados, contraria imensamente o interesse das concessionárias, dando origem aos numerosos conflitos que se seguiram.

\subsection{As propostas do projeto RESEB para as cooperativas de eletrificação rural}

Em 7 de julho de 1995 foi publicada a Lei 9.074, ainda sob a existência do DNAEE. Em 1997 foi constituída a Agência Nacional de Energia Elétrica - Aneel, em substituição ao DNAEE, e com novas e mais importantes atribuições.

A Aneel, juridicamente estabelecida pela Lei 9.427, faz parte do conjunto de ações decorrentes da Reforma do Estado, que criou, no processo de privatização das empresas prestadoras de serviços públicos, órgãos reguladores desses serviços. 
O Estado saía de uma forma de intervenção direta para uma nova forma de intervenção estatal, através das agências reguladoras. MARQUES NETO (2003) afirma que essa forma de intervenção difere da anterior nos seguintes aspectos:

- Nos seus pressupostos, à medida que a intervenção regulatória é muito mais pautada pelo caráter de mediação que pela imposição de objetivos e comportamentos ditada pelo Estado.

- Nos seus objetivos, pois estes se deslocam dos interesses do Estado-nação e passam a se identificar mais com os interesses da sociedade (cidadãos e agentes econômicos).

- Nos seus instrumentos, porque a regulação demanda a construção de mecanismos de intervenção estatal que permitam efetivar uma nova forma de relacionamento com os agentes econômicos, através da interlocução com os agentes envolvidos no setor regulado.

O mesmo autor faz distinção entre a atividade regulatória e atividade regulamentar:

"A atividade de regulação estatal (grifo original) envolve funções muito mais amplas do que a função regulamentar (grifo original). Esta consiste em disciplinar uma atividade mediante a emissão de comandos normativos, de caráter geral, ainda que com abrangência meramente setorial. A regulação estatal envolve atividades coercitivas, adjudicatórias, de coordenação e organização, funções de fiscalização, sancionatórias, de conciliação (composição e arbitragem de interesses), bem como o exercício de poderes coercitivos e funções de subsidiar e recomendar a adoção de medidas de ordem geral pelo poder central."'(MARQUES NETO, 2003, pg.56)

A Aneel faz a função regulatória e regulamentar para o setor elétrico. $\mathrm{O}$ processo de regularização de cooperativas de eletrificação rural é um processo de regulação, consubstanciado na edição de regulamentos que norteiam o processo.

Particularmente, esse processo contém todas as funções regulatórias apontadas por Marques Neto. É um exercício completo e pleno da regulação em estado puro. 
A Aneel é um órgão cuja abrangência é nacional. Num país de dimensões continentais como o Brasil, torna-se difícil a sua presença constante em todos os locais onde é necessária. Por essa razão, a agência pratica uma política de descentralização de atividades, através da realização de convênios com órgãos estaduais aptos a desempenhar algumas funções que a lei permite que sejam delegadas, como as atividades de fiscalização técnica, comercial e econômicofinanceira e apoio à regulação. É um modelo único do setor elétrico que, ao contrário de outros setores federais com agências reguladoras, não realiza a descentralização através da abertura de escritórios regionais.

No estado de São Paulo, o órgão que faz esse papel é a Comissão de Serviços Públicos de Energia (CSPE), autarquia especial vinculada ao governo do estado, criada pela Lei Complementar Estadual n ${ }^{0}$ 833/97. A CSPE foi criada dentro do processo de reestruturação do setor elétrico paulista, que envolveu a desverticalização e a privatização das atividades de geração e distribuição de energia. A CSPE também atua, como reguladora e fiscalizadora, no setor de distribuição de gás canalizado.

No Rio Grande do Sul, quem faz esse papel é a Agência Estadual de Regulação dos Serviços Públicos Delegados do Rio Grande do Sul - Agergs. A Agergs é uma agência múltipla, como quase todas as outras agências estaduais, isto é, além de serviços de energia, regula também serviços de transporte e saneamento.

Apenas em julho de 1999, portanto 4 anos após a publicação da lei 9.074, o órgão regulador colocou em audiência pública uma minuta de regulamento, em forma de Resolução, para aplicar efetivamente o disposto no Art. 23 e acertar a vida das cooperativas de eletrificação rural existentes. Esta demora é um dos principais motivos de conflito e desacertos dentro do processo de regularização das cooperativas de eletrificação rural.

Antes disso, porém, dentro do processo de reestruturação do setor elétrico, o projeto RESEB estudou a questão das cooperativas e da eletrificação rural. As conclusões deste estudo estão descritas no Relatório VI-2, de dezembro de 1997. 
Em resumo, o relatório realiza um diagnóstico das cooperativas brasileiras e analisa os aspectos jurídicos, regulatórios e econômico-financeiros para a regularização, além de dedicar uma parte do estudo aos mecanismos necessários para expandir a eletrificação rural. Os principais pontos do relatório são (COOPERS \& LYBRAND, 1997):

\section{Diagnóstico:}

- O Brasil apresenta índices muito baixos de penetração de energia elétrica no meio rural.

- Existem cerca de 200 cooperativas, atendendo aproximadamente 460.000 consumidores em todo o Brasil. Sua atuação varia muito de Estado para Estado, sendo predominantes na região Sul.

- As cooperativas são bastante díspares, com porte variando de uma centena de consumidores até mais de 30.000 , e com mix de mercado entre $100 \%$ rural e 100 \% não-rural.

- Há um problema crônico de relacionamento institucional entre as cooperativas e concessionárias, sendo que o ponto de maior atrito é o de superposição de áreas de atuação, gerando disputas injustificadas por mercados e onerando o consumidor final.

- Grande parte das dificuldades podem ser atribuídas a um grande hiato regulatório, na definição dos direitos e obrigações de uma permissionária de energia elétrica, bem como na diferenciação entre concessão e permissão.

\section{$\underline{\text { Aspectos Jurídicos }}$}

- Recomendação para que o Poder Concedente defina áreas exclusivas de atuação para concessionárias e permissionárias, para reduzir conflitos e determinar o agente que terá obrigação de servir os clientes cativos da área. 
- Recomendação para regularização das cooperativas de eletrificação rural como permissionárias de serviço público, celebrando um Contrato de Adesão com o Poder Concedente.

- Dificuldade jurídica de conciliar o papel de cooperativa de eletrificação rural com o de uma prestadora de serviços públicos. O ideal seria que fossem transformadas em empresas.

\section{Aspectos Regulatórios}

- As permissionárias devem seguir as regulamentações do serviço público. As de menor porte, inferiores a 1.000 consumidores estariam isentas dessas obrigações e as de porte médio (abaixo de 10.000 consumidores) teriam algumas simplificações, como: obrigação de manter contabilidade separada somente entre atividades do setor elétrico e outras; processo de revisão tarifária simplificado; procedimentos simplificados de medição de desempenho e aplicação de penalidades; simplificação da estrutura tarifária; padrões técnicos adaptados à realidade gerencial e ao mercado; padrões para atendimento ao consumidor menos exigentes.

\section{$\underline{\text { Aspectos Econômico-Financeiros }}$}

- Recomenda-se que se estabeleça uma taxa de retorno sobre os investimentos. É sugerido o valor de $6 \%$.

- Recomenda-se fornecer descontos nas tarifas de suprimento somente para os mercados rurais. Os mercados não-rurais não devem ter desconto. $\mathrm{O}$ ônus dos descontos deve incidir sobre a concessionária local.

- A política de preços que for praticada para as cooperativas deve ser transparente, criando ao mesmo tempo incentivos regulatórios para melhoria da eficiência.

A principal recomendação do Relatório é a regularização das cooperativas de eletrificação rural como permissionárias, e o reconhecimento de que o principal 
problema é a compatibilização de áreas de atuação. É bastante enfatizada a grande diversidade existente entre as cooperativas, e termina com um receituário contraditório: apesar da recomendação de enquadrar todas as cooperativas como permissionárias, sugere-se a isenção e simplificação das exigências regulatórias para as de menor porte.

Durante o ano de 1998, o consórcio do projeto RESEB continuou o trabalho sobre as cooperativas, elaborando dois Working Papers visando orientar a Aneel na regulamentação, inclusive dispondo sobre o conteúdo de uma resolução de regularização e de um modelo de contrato de adesão.

Aparentemente, foi solicitada ao consórcio uma análise jurídica mais aprofundada da questão da regularização, pois o primeiro Working Paper (WP 98/4/1-1) visava

"elencar os problemas legais e econômicos que envolvem as cooperativas de eletrificação rural para que seja proposta uma forma de regularização das mesmas. "(COOPERS \& LYBRAND, 1998, pg. 4)

No WP 98/4/1-1, além de uma análise bastante extensa sobre o histórico das cooperativas e dos instrumentos legais, aparece pela primeira vez a sugestão do uso do instrumento da autorização para a regularização de algumas cooperativas de eletrificação rural. Segundo o documento

“(...) o título de Autorizadas de Serviços e Instalações de Energia Elétrica para Uso Privativo deveriam ser outorgados às $C E R^{13}$, nos termos do Decreto 62.655, de 3 de maio de 1968, que regulamenta a execução de serviços de eletrificação rural para uso privativo. Por sua vez, o título de Permissionária de Serviços Públicos de Energia Elétrica, deveria ser outorgado às CER nos termos do Art. 23 da Lei 9.074, de 8 de julho de 1995, que prevê a regularização das CER que prestam serviço público a público indistinto.

O Consórcio (...) enfatiza que a aplicação prática de ambos os conceitos dependerá de ajustes a serem feitos na legislação vigente. O Consórcio também vislumbra a necessidade da definição de áreas não superpostas na prestação dos serviços de distribuição de energia elétrica para as CER regularizadas como permissionárias, como sendo a única maneira de

\footnotetext{
${ }^{13}$ CER: Cooperativa de Eletrificação Rural.
} 
solução dos conflitos hoje existentes e para melhor traçar a obrigação de servir das permissionárias." (COOPERS \& LYBRAND, 1998, pg. 5)

Há uma clara mudança de posição, eliminando a contradição apontada. O reconhecimento da existência de duas classes de cooperativas, as que atendem público predominantemente rural e as que atendem a público indistinto, serve agora para diferenciá-las também no regime legal de atuação, como autorizada ou como permissionária. Segundo o documento, seriam enquadradas como autorizadas as cooperativas que atendessem os seguintes critérios:

- ' “CER, indivíduos ou associações, que preencham os requisitos do Art. $1^{\circ}$ do Decreto 62.655/68;

- Comprovação da aquisição de energia para USO PRIVATIVO (grifo original) das CER, indivíduos ou associações, que não importe na execução de atividades de distribuição e comercialização desta energia a terceiros, como forma de exploração de atividade econômica;

- Comprovação da detenção de ativos de serviços e instalações de energia elétrica (subestações, redes predominantemente de baixa tensão - inferior a $13,8 k V$, transformadores, medidores, etc); e

- Apresentação da documentação e das declarações constantes do Art. $4^{\circ}$ do Decreto 62.655/68." (COOPERS \& LYBRAND, 1998, pg. 27)

Como permissionárias, seriam enquadradas as cooperativas com os seguintes critérios:

- “CER que já prestavam, em julho de 1995, serviços de distribuição e comercialização de energia elétrica a público indistinto, sejam cooperados ou terceiros;

- Comprovação de capacidade técnica e porte suficiente para o atendimento de seus consumidores, apresentando, para tanto, número total de consumidores, número de empregados da CER, tensões de utilização, estruturas para os serviços de manutenção, normas e procedimentos utilizados;

- Comprovação da detenção de ativos, incluindo-se ativos de transmissão e distribuição de energia elétrica;

- Demonstração de autonomia administrativa e operacional." (COOPERS \& LYBRAND, 1998, pg. 28) 
Fica claro, principalmente pelo terceiro critério apresentado, detenção de propriedades de redes predominantemente de baixa tensão, que a figura da autorizada destina-se principalmente à regularização das cooperativas do Nordeste, que são as que possuem estas características. Assim, volta-se a usar a permissão como um instrumento muito semelhante à concessão.

A novidade é a abertura para que a Aneel promova a efetivação de outras Autorizadas, que não sejam cooperativas ou indivíduos cobertos pelo Decreto $62.655 / 68$, ou seja, que a autorização possa ser outorgada a consumidores não rurais. Para justificar esse ponto, o trabalho baseia-se no Art. 66, “c” do Decreto 41.019, de 26.02.1957, que regulamentou os serviços de energia elétrica nos termos do Código de Águas (Decreto 24.643, de 10.07.1937), e que estabelece:

“Art. 66 - Depende de autorização federal a execução dos serviços:

\section{(...)}

c) de transmissão e distribuição de energia elétrica, quando se destinem ao uso exclusivo do permissionário.

\section{(...)}

$\S 2^{\circ}$ - São considerados de uso exclusivo dos respectivos permissionários a iluminação elétrica de estradas, ruas e logradouros, e os consumos domésticos em vilas operárias de indústrias providas de serviços próprios de energia e construídas em terrenos pertencentes a essas mesmas indústrias."

Para justificar a utilização desse artigo para abrir novas autorizações, o consórcio usa o seguinte argumento:

"Embora o parágrafo segundo deste artigo tenha, de certa forma, restringido o conceito de uso exclusivo, entendemos que este rol não é exaustivo, podendo, portanto, ser ampliado.

Diferentemente das concessões e permissões, não é necessário lei autorizativa para outorga de autorizações, embora na legislação recente sobre a matéria, esteja constando as hipóteses de outorga de autorização pelo poder concedente." (COOPERS \& LYBRAND, 1998, pg. 31)

Uma argumentação que não é muito consistente, e que foi a causa de vários questionamentos posteriores. 
Em julho de 1999, a Aneel coloca em audiência pública uma proposta de resolução, já incorporando o instrumento da autorização, conforme sugerido pelo projeto RESEB. Optou-se então, por uma resolução de caráter abrangente, que não incluísse apenas a regularização de cooperativas, mas também regulamentasse, em caráter geral, os instrumentos da permissão e autorização na distribuição de energia elétrica.

\subsection{A Resolução 333/99}

Em dezembro de 1999 a Aneel emitiu a Resolução 333/99, disciplinando o processo de regularização das cooperativas previsto na lei 9.074.

Além de regulamentar o processo de regularização, a resolução abrangiu a definição dos instrumentos da autorização e da permissão na distribuição de energia elétrica. O escopo da resolução era formado pelo seguinte:

- Definição do instrumento da autorização.

- Definição do instrumento da permissão.

- Descrição dos procedimentos para regularização das cooperativas.

- Descrição dos procedimentos para definição das áreas de atuação.

Assim, a resolução definiu que, a partir da análise da documentação a ser enviada pela cooperativa, e de diligências realizadas pelo poder concedente, ela poderia ser regularizada de duas maneiras:

- Como autorizada para implantação de instalações de uso privativo, onde a cooperativa continuaria com quase o mesmo status e procedimentos como os existentes hoje, ou seja, com tarifas e serviços não-regulados. Esse enquadramento só vale para aquelas que não possuem atendimento a público indistinto, sendo predominantemente rurais. Assim, não é permitida a comercialização de energia elétrica, e sim apenas o rateio dos custos com a compra de energia e a operação e manutenção do sistema. A cooperativa 
autorizada também não possui exclusividade de atendimento, podendo a concessionária atender consumidores na área de atuação da cooperativa, seja através da extensão de novas redes ou através do uso das redes da cooperativa, mediante um acordo formal, remunerado ou não. A cooperativa autorizada, em princípio, mantém os descontos a que tem direito hoje na compra de energia.

- Como permissionária de serviço público: nesta modalidade, a cooperativa deve assinar um contrato de adesão à permissão, onde se submete às normas do poder concedente em relação às tarifas e prestação do serviço. Em contrapartida, é garantido o equilíbrio econômico-financeiro da permissão. O instrumento em si é bastante semelhante ao da concessão, tendo apenas um grau de precariedade maior, em relação aos procedimentos de extinção ou cassação da permissão. Serão enquadradas nessa modalidade as cooperativas que atendem a público indistinto. Em princípio, uma permissionária deveria competir no mercado livre, comprando energia sem desconto. Entretanto, as cooperativas permissionárias não possuem um mercado que lhes dê escala para isso. Assim, foi prevista na Resolução 333/99 a existência de mecanismos compensatórios que, entretanto, não foram detalhados, deixando-se para um outro regulamento.

Para a cooperativa permissionária, é necessária a definição de uma área de atuação para fins de regularização. Nesta área, a cooperativa possui as prerrogativas e a obrigação de prestar o serviço de distribuição de modo exclusivo (serviço de rede) e também de comercialização para os clientes cativos. Para tanto, a resolução prevê o estabelecimento de uma poligonal envolvente, que defina esta área. Esta poligonal deve ser definida de comum acordo entre a cooperativa e a(s) concessionária(s) onde a cooperativa atua. Em outras palavras, significa "recortar" um pedaço da área de concessão da concessionária, onde há atuação da cooperativa, e defini-la como área de permissão desta.

Este ponto é um dos principais focos dos conflitos com as concessionárias. Muitas entendem que a área da cooperativa permissionária deveria se restringir àquela em que havia fundamentação legal para atuação, que são as portarias do antigo DNAEE que definiam, de modo bastante geral, as áreas da cooperativa. 
Assim, a área da cooperativa permissionária seria apenas aquela das instalações iniciais e não abrangeria as expansões realizadas pela cooperativa ${ }^{14}$. Como na verdade, as expansões foram realizadas num vácuo regulatório, entende a agência reguladora que vale o disposto no Art. 23 da Lei 9.074, que considera o fato, e não o disposto no direito. Assim, a área da cooperativa é aquela onde de fato ela possui instalação e atende a público indistinto.

A Resolução 333/99 representou o que se imaginava como marco legal definitivo para a regularização das cooperativas de eletrificação rural. A partir daí iniciou-se realmente o processo de conhecimento e formalização de sua inserção no novo modelo do setor. Também foi, a partir daí, que realmente ficou claro para a agência as dificuldades do processo.

Boa parte da experiência da Aneel com o processo de regularização que se iniciou aí veio de sua atuação em conjunto com a CSPE em São Paulo, fruto de um esforço comum de pesquisa entre a universidade e as duas agências. Os próximos capítulos deste trabalho irão mostrar como essa pesquisa se desenvolveu.

\footnotetext{
${ }^{14} \mathrm{Na}$ verdade, definiam os municípios em que ela podia atuar, a partir da aprovação dos projetos apresentados.
} 


\section{CAPÍTULO 5 - PESQUISADORES CHAMADOS PARA PENSAR \\ E CONDUZIR O PROCESSO DE CONHECIMENTO DA SITUAÇÃO EM SÃO PAULO}

\subsection{A necessidade da pesquisa}

A Aneel soube fazer uso das universidades brasileiras nos processos de inspeção e fiscalização inicial de todas as concessionárias brasileiras, logo após a própria criação da agência. Equipes de engenheiros professores universitários correram do Oiapoque ao Chuí, do Cabo Branco ao Rio Javari, vendo postes e linhas, subestações, usinas e as contas das empresas. Criou-se uma experiência relevante. Os resultados dessa experiência são as próprias informações que servem de base para as atividades da Aneel, principalmente as atividades iniciais.

Ficou patente a adequação da universidade para pensar junto com os reguladores com os olhos voltados para o objetivo de melhor atendimento do serviço público, desenvolvimento nacional e respeito ao cidadão consumidor. O espírito da investigação, próprio dos universitários, também se revelou de muita utilidade para os primeiros trabalhos de inspeção e fiscalização isentos.

Algum tempo após essa fase, entrou em pauta um problema complicado: o das velhas cooperativas de eletrificação rural. O setor elétrico sempre as quis engolir, elas sempre se mostraram indigestas. Conflitos de décadas deveriam explodir justo na hora de se iniciar uma atividade de regulação totalmente experimental.

A Universidade de São Paulo era a única instituição com equipe de pesquisa sobre o tema de políticas públicas de eletrificação rural, dentro do Departamento de Engenharia de Energia e Automação Elétricas da Escola Politécnica - PEA/EPUSP. Várias participações em congressos, várias dissertações de mestrado, uma livre docência, até uma sala sobre eletrificação rural, talvez a única da universidade brasileira. 
A Faculdade de Engenharia de Guaratinguetá, da Universidade Estadual Paulista - Unesp, a universidade pública estadual com o espírito do interior paulista - já participara das atividades de inspeção e fiscalização da Aneel no interior do Brasil, como Mato Grosso e Roraima.

$\mathrm{Na}$ prática, apenas com o início do processo de elaboração de uma resolução, que veio a culminar na Resolução 333/99, as cooperativas de eletrificação rural deixaram de ser uma preocupação remota para se tornar um fato preocupante: entrou na pauta da Aneel o problema da regularização. Discussões, e até algumas ações já houvera. De repente, o grande problema tomou corpo.

A Aneel, usando a estrutura da CSPE, pioneira em muitas ações, decidiu começar a regularização pelo estado de São Paulo. Ficou decidida a participação da Fundunesp (fundação de direito privado sem fins lucrativos vinculada à Unesp), juntamente com a equipe do PEA/EPUSP, para ajudar a pensar e resolver o problema.

O autor, mestre em avaliação de política de eletrificação rural, fez parte da equipe de pesquisadores da Fundunesp. A equipe inicial teve um total de 12 pessoas, entre docentes da própria Unesp, da USP e alunos de cursos de doutorado. Dez pessoas foram designadas para os serviços de inspeção em campo.

Imaginando-se, de início, um membro executor de trabalhos de formulação definida, o autor foi percebendo que tinha mais horas de pesquisa em eletrificação rural, quilômetros percorridos atrás de áreas rurais sem luz elétrica, e contatos com responsáveis regionais por distribuição rural que boa parte dos reguladores envolvidos no problema das cooperativas. Mais tarde, quando coube a ele participar da condução do processo como regulador em São Paulo, esta experiência foi um dos motivadores a continuar a pesquisa, agora mais próximo do problema da regulação do serviço público de energia elétrica. 


\subsection{Os procedimentos de pesquisa na CSPE}

Em meados de 1999 iniciaram-se os procedimentos de pesquisa. Através de uma visita à Aneel, localizaram-se documentos importantes, que estavam arquivados pelo governo federal. Foi possível obter cópias de todos os atos de permissão expedidos em favor de Cooperativas de Eletrificação Rural para o estado de São Paulo em décadas de atividades. Foi constatado que havia 43 atos de permissão para execução de obras de transmissão e distribuição de energia elétrica, que contemplavam 33 cooperativas, fundamentados no Decreto 62.655/68. A maioria absoluta destes atos de permissão foi outorgada através de Portarias da extinta Divisão de Concessão de Águas e Eletricidade - DCAE, do Ministério de Minas e Energia.

Em paralelo, foi realizado um contato com a Fecoeresp, que permitiu identificar, dentre as 33 cooperativas, as dezessete cooperativas de eletrificação rural atuantes e filiadas à federação:

1. CEDRAP - Cooperativa de Eletrificação e Desenvolvimento Rural do Alto Paraíba Ltda.

2. CEDRI - Cooperativa de Energização e Desenvolvimento Rural do Vale do Itariri.

3. CEMIRIM - Cooperativa de Eletrificação e Desenvolvimento da Região de Mogi Mirim.

4. CERFRA - Cooperativa de Eletrificação e Desenvolvimento da Região de Franca.

5. CERIM - Cooperativa Agrícola Mista e de Eletrificação Rural Itu-Mairinque.

6. CERIPA - Cooperativa de Eletrificação Rural de Itaí-Paranapanema-Avaré.

7. CERIS - Cooperativa de Eletrificação Rural da Região de Itapecerica da Serra.

8. CERMC - Cooperativa de Eletrificação Rural de Mogi das Cruzes. 
9. CERMESO - Cooperativa de Eletrificação Rural da Média Sorocabana.

10. CERNHE - Cooperativa de Energização e Desenvolvimento Rural de Novo Horizonte Ltda.

11. CEROC - Cooperativa de Eletrificação Rural da Região de Osvaldo Cruz.

12. CERPAL - Cooperativa de Eletrificação Rural da Região de Palmital.

13. CERPRO - Cooperativa de Eletrificação Rural da Região de Promissão.

14. CERRP - Cooperativa de Eletrificação Rural da Região de São José do Rio Preto.

15. CERT - Cooperativa de Eletrificação Rural da Região de Tupã.

16. CERVAM - Cooperativa de Energização e de Desenvolvimento Rural do Vale do Mogi.

17. CETRIL - Cooperativa de Eletrificação e Telefonia Rurais de Ibiúna Ltda.

Outras dezesseis cooperativas já haviam sido extintas, tendo suas instalações encampadas pelas respectivas concessionárias fornecedoras de energia:

1. CAERPA - Cooperativa de Eletrificação Rural da Região de Paraguaçu Paulista.

2. CERRO - Cooperativa de Eletrificação Rural de Orindiúva Ltda.

3. CERSA - Cooperativa de Eletrificação Rural de Salesópolis.

4. CERSO - Cooperativa de Eletrificação Rural de Socorro Ltda.

5. CERUJ - Cooperativa de Eletrificação Rural de Urânia-Jales Ltda.

6. CETERT - Cooperativa de Eletrificação e Telefonia Rurais de Tapiraí.

7. CETERUSP - Cooperativa de Eletrificação e Telefonia Rurais da região de São Pedro Ltda. 
8. CETRUR - Cooperativa de Eletrificação e Telefonia Rurais de Registro Ltda.

9. CERSJ - Cooperativa de Eletrificação Rural de São João da Boa Vista ${ }^{15}$.

10. CERALP - Cooperativa de Eletrificação Rural da Alta Paulista (Tupi Paulista e Região)

11. Cooperativa de Eletrificação Rural de Bariri Ltda.

12. Cooperativa de Eletrificação Rural da Região de Presidente Prudente Ltda.

13. Cooperativa de Eletrificação Rural de Rio Acima Sabaúma Ltda. (Região de Biritiba Mirim)

14. Cooperativa de Eletrificação Rural da Região de Tietê Ltda.

15. Cooperativa de Eletrificação Rural do Médio Paraíba Ltda. (Cachoeira Paulista e Região)

16. Cooperativa de Eletrificação Rural de Atibaia.

O passo seguinte foi a realização de inspeções técnicas nas cooperativas atuantes. Feita por professores universitários e pesquisadores da área de energia, teve um indisfarçável viés de pesquisa de engenharia nos seus cuidados metodológicos e operacionais.

Os cuidados metodológicos eram, também, uma demanda criada pelo inusitado da situação de transição regulatória. A metodologia desenvolvida pelos pesquisadores serviu de base para as inspeções da Aneel nas demais cooperativas brasileiras, que provavelmente seriam feitas por instituições locais. A experiência da Aneel e do grupo de pesquisadores em trabalhos de fiscalização contribuiu também bastante para o desenvolvimento da metodologia.

\footnotetext{
${ }^{15}$ Esta foi a primeira a ser constituída, segundo a Fecoeresp.
} 
O objetivo traçado foi de realizar um retrato abrangente das cooperativas de São Paulo, preparando-as e à agência para o processo de regularização que teve início com a publicação da Resolução 333/99.

Os trabalhos foram desenvolvidos em 3 fases:

A. Obtenção de dados preliminares.

B. Realização de visitas de inspeção para avaliação de aspectos técnicos e comerciais.

C. Apresentação dos resultados.

$\mathrm{Na}$ fase $\mathrm{A}$, a equipe de pesquisa, junto com a CSPE, visitou a sede da Fecoeresp, então na cidade de Mogi Mirim, onde foram expostos os objetivos do trabalho, a necessidade do processo de regularização e a solicitação de colaboração na obtenção dos dados.

Em seguida, foi remetido a todas as cooperativas um formulário, elaborado pelos pesquisadores, com anuência da CSPE/Aneel, intitulado "Informações do Desempenho Técnico Operacional e Comercial". O formulário procura atender às exigências que viriam a ser solicitadas na resolução a ser emitida pela Aneel, de modo a antecipar o processo de regularização. Foram solicitadas informações sobre a qualificação jurídica, técnica e administrativa das cooperativas de eletrificação rural. Houve também a intenção de solicitar informações que pudessem passar por uma análise de consistência por ocasião da inspeção em campo.

Os tópicos constantes do formulário eram:

- Informações Gerais da Cooperativa:

- Ficha Técnica: dados cadastrais, composição da diretoria, informações sobre consumidores.

- Dados Físicos sobre a rede elétrica: subestações, linhas de transmissão e distribuição, mapa e diagrama unifilar da rede. 
- Suprimento de Energia Elétrica: tomadas de energia, histórico do consumo, níveis de tensão e continuidade.

- Mercado de Energia Elétrica: energia faturada anual, consumidores de média tensão, consumidores por classe e estimativa do mercado por atender.

- Procedimentos Técnicos:

- Planos de Obras e Investimento: descrição, montante de investimentos.

- Normas Técnicas e Padrões: relação dos utilizados.

- Segurança: acidentes nos últimos 5 anos, descrição de programas de prevenção.

- Desempenho Comercial:

- Atendimento ao Consumidor: número de escritórios e atendentes, serviço de atendimento telefônico.

- Medição: procedimentos de medição de consumidores.

- Faturamento/Arrecadação: custo da energia adquirida e distribuída, total e por classe de consumidor, valores de tarifa e taxas, formas de cobrança.

Houve a resposta de todas as cooperativas, que entregaram as informações tão detalhadamente quanto dispunham dos dados solicitados.

A fase B compreendeu a realização de visitas de inspeção em campo, realizada por equipes de dois pesquisadores, com duração de 2 a 3 dias. Para essa atividade foi elaborado um roteiro intitulado "Inspeção técnica e comercial - check list", visando colher informações em campo. Este roteiro também teve a intenção de uniformizar as rotinas de inspeções realizadas, de forma a se obter um retrato uniforme dos procedimentos inspecionados. A inspeção teve como foco verificar "in loco" os procedimentos realizados pela cooperativa em vários tipos de atividades, recolhendo-se registros fotográficos e cópias de alguns documentos importantes. Os 
itens que fizeram parte deste roteiro, e que foram objeto de inspeção, são mostrados abaixo:

- Informações Gerais sobre Faturamento e Arrecadação: procedimentos, cópia de faturas.

- Informações Gerais sobre Suspensão e Religação: procedimentos, débitos em carteira, pendências judiciais.

- Atendimento Comercial: procedimentos, visita aos escritórios, observação da estrutura.

- Cadastro: dados e procedimentos de atualização, cópia de ficha cadastral.

- Atendimento de novas ligações em baixa tensão com existência de rede: número de atendimentos, procedimentos de ligação e inspeção, procedimentos para aumento de carga, pontos de conflito com a concessionária.

- Atendimento de novas ligações em baixa tensão com reforço ou extensão de rede: número de solicitações, participação do consumidor.

- Outras informações de interesse comercial: fraudes, divulgação de riscos, procedimentos de ressarcimento por danos.

- Aspectos Operacionais da Distribuição: COD (Centro de Operação da Distribuição), atendimento de emergência, gerenciamento de rede, Nota de Ocorrência, apuração de indicadores de qualidade, plano de emergência, meios de comunicação, taxas cobradas, dispositivos de segurança, inspeção da frota, relato de incidentes operacionais.

- Aspectos relativos à Manutenção Preventiva: atividades, funcionários envolvidos, estimativa de falhas.

- Aspectos de Engenharia: tipos de rede, condutores, postes, critérios de queda de tensão e proteção, padronização de equipamentos, carregamento de transformadores, registros fotográficos dos principais tipos de instalação. 
- Entrevistas com consumidores, antigos e recém-ligados, para verificação de procedimentos e comparação de dados cadastrais.

Além das entrevistas, a inspeção envolveu o registro fotográfico das instalações da cooperativa, dos pontos de suprimento de energia elétrica e da sede. Especial atenção foi dada para os pontos onde havia conflitos, como cruzamento e paralelismo de redes, com a concessionária.

A fase $\mathrm{C}$ compreendeu a apresentação dos resultados obtidos através do formulário e das inspeções. Foram produzidos relatórios para cada cooperativa, que depois fizeram parte do processo administrativo de regularização. Os dados comparativos entre as cooperativas foram também consolidados num relatório resumo.

A pesquisa, nessa etapa, se encerrou com a apresentação das impressões dos inspetores sobre cada cooperativa à CSPE, realizada num seminário na Faculdade de Engenharia de Guaratinguetá, no final de 1999.

O próximo capítulo faz um retrato das cooperativas de eletrificação rural de São Paulo, baseado nos resultados dessa pesquisa. 


\section{CAPÍTULO 6 - AS COOPERATIVAS DE ELETRIFICAÇÃO RURAL EM SÃO PAULO}

\subsection{Introdução}

A pesquisa realizada pela CSPE em 1999 permitiu traçar um quadro bastante amplo das cooperativas de eletrificação rural de São Paulo. Este capítulo pretende mostrar os principais dados obtidos referentes a aspectos físicos e de mercado, visando realizar uma comparação entre todas elas.

Alguns dados foram atualizados posteriormente pela própria CSPE, por meio de pedido às cooperativas, realizado em 2000 e 2002. Os números mostrados procuram refletir essas atualizações, quando possível, sendo indicado no respectivo gráfico ou tabela.

\subsection{Dados físicos das cooperativas de São Paulo}

As dezessete cooperativas de eletrificação rural do estado de São Paulo são supridas de energia por intermédio de tomadas de energia ou subestações. Quase todas as quatorze concessionárias do estado fornecem energia a uma cooperativa. A tabela 6.1 mostra, para cada cooperativa, as concessionárias supridoras e o seu município sede. 
Tabela 6.1 - Supridoras e municípios sede das cooperativas

\begin{tabular}{|l|l|l|}
\hline \multicolumn{1}{|c|}{ COOPERATIVA } & \multicolumn{1}{|c|}{$\begin{array}{c}\text { CONCESSIONÁRIAS } \\
\text { SUPRIDORAS }\end{array}$} & \multicolumn{1}{|c|}{ MUNICÍPIO SEDE } \\
\hline CEDRAP & Elektro e Bandeirante & Paraibuna \\
\hline CEDRI & Elektro & Itariri \\
\hline CEMIRIM & CPFL, Elektro e Jaguari & Mogi Mirim \\
\hline CERFRA & CPFL & São José da BelaVista \\
\hline CERIM & CPFL - Piratininga & Itu \\
\hline CERIPA & Sta.Cruz, Elektro e CPFL & Itaí \\
\hline CERIS & Eletropaulo & Itapecerica da Serra \\
\hline CERMC & Bandeirante & Mogi das Cruzes \\
\hline CERMESO & Sta. Cruz & Manduri \\
\hline CERNHE & CNEE & Novo Horizonte \\
\hline CEROC & Caiuá & Osvaldo Cruz \\
\hline CERPAL & EEVP & Palmital \\
\hline CERPRO & CPFL & Promissão \\
\hline CERRP & CPFL e CNEE & São José do Rio Preto \\
\hline CERT & EEVP & Tupã \\
\hline CERVAM & Elektro & Porto Ferreira \\
\hline CETRIL & CPFL - Piratininga e Elektro & Ibiúna \\
\hline Fonte: CSPE. & &
\end{tabular}

As cooperativas atendem consumidores em 113 municípios, espalhados pelo estado. A figura 6.1 mostra os municípios onde elas têm instalações para atendimento de pelo menos um consumidor. Nem toda a área do município assinalado é atendida pela cooperativa. O núcleo urbano não o é, sendo mais freqüente o atendimento da zona rural. O único município integralmente atendido por uma cooperativa é o de Holambra, pela Cemirim. 
Figura 6.1 - Municípios com instalações de cooperativas

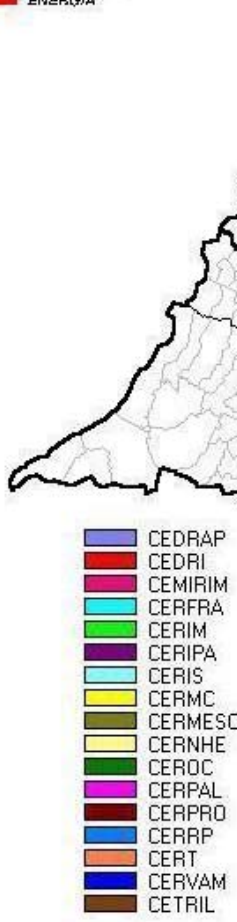

ATENCA0: Etäo indicados a extensino total do municipio onde atuan as cooperativas, até que sẹjam regulaizadas.

Fonte: CSPE.

Os principais dados físicos das cooperativas de São Paulo são mostrados na Tabela 6.2 e nas Figuras 6.2, 6.3 e 6.4. Os dados se referem ao ano de 2001, exceto quando indicado. São valores informados pelas cooperativas, e que não foram verificados pela CSPE, o que pode induzir a alguns erros, por conta da deficiência cadastral de algumas delas. 
Tabela 6.2 - Dados Físicos da rede das cooperativas de São Paulo

\begin{tabular}{|l|c|c|c|c|}
\hline Cooperativa & $\begin{array}{c}\text { Extensão de } \\
\text { Rede MT (km) }\end{array}$ & $\begin{array}{c}\text { Extensão de } \\
\text { Rede BT (km) }\end{array}$ & $\begin{array}{c}\text { Número de } \\
\text { Transformadores }\end{array}$ & $\begin{array}{c}\text { Potência } \\
\text { Instalada (kVA) }\end{array}$ \\
\hline CEDRAP & 544 & 153 & 759 & $16.247(1999)$ \\
\hline CEDRI (1999) & 326 & 44 & 589 & 7.035 \\
\hline CEMIRIM & 998 & 113 & 2.320 & 72.720 \\
\hline CERFRA & 398 & 18 & 647 & 11.612 \\
\hline CERIM & 481 & 301 & 1.179 & 25.794 \\
\hline CERIPA & 1.680 & 115 & 2.218 & 45.000 \\
\hline CERIS & 313 & 99 & 661 & 22.580 \\
\hline CERMC & 148 & 57 & 403 & 13.925 \\
\hline CERMESO & 560 & 43 & 713 & 11.308 \\
\hline CERNHE & 907 & 50 & 1.280 & $13.360(1999)$ \\
\hline CEROC & 654 & 81 & 925 & 14.456 \\
\hline CERPAL & 597 & 53 & 843 & 9.450 \\
\hline CERPRO & 496 & 36 & 685 & 11.772 \\
\hline CERRP & 597 & 47 & 1.085 & 18.985 \\
\hline CERVAM & 456 & 50 & 714 & 24.172 \\
\hline CERT & 676 & 49 & 934 & 15.476 \\
\hline CETRIL & 944 & 379 & 2.467 & 87.214 \\
\hline Total & 10.775 & 1.688 & 24.868 & 391.499 \\
\hline Fote $C S P E$ & & & &
\end{tabular}

Fonte: CSPE.

Figura 6.2 - Comparativo entre as extensões de rede das cooperativas

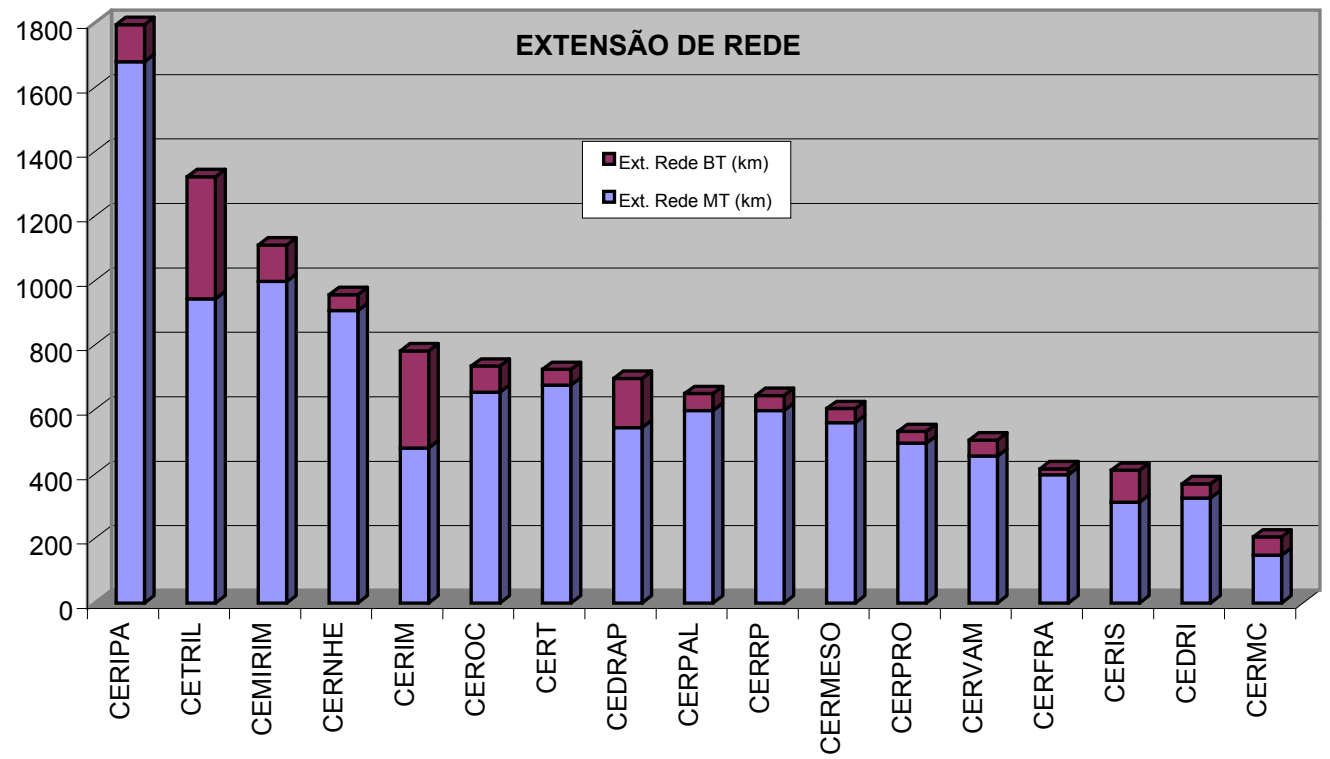


Figura 6.3 - Comparativo entre o número de transformadores das cooperativas

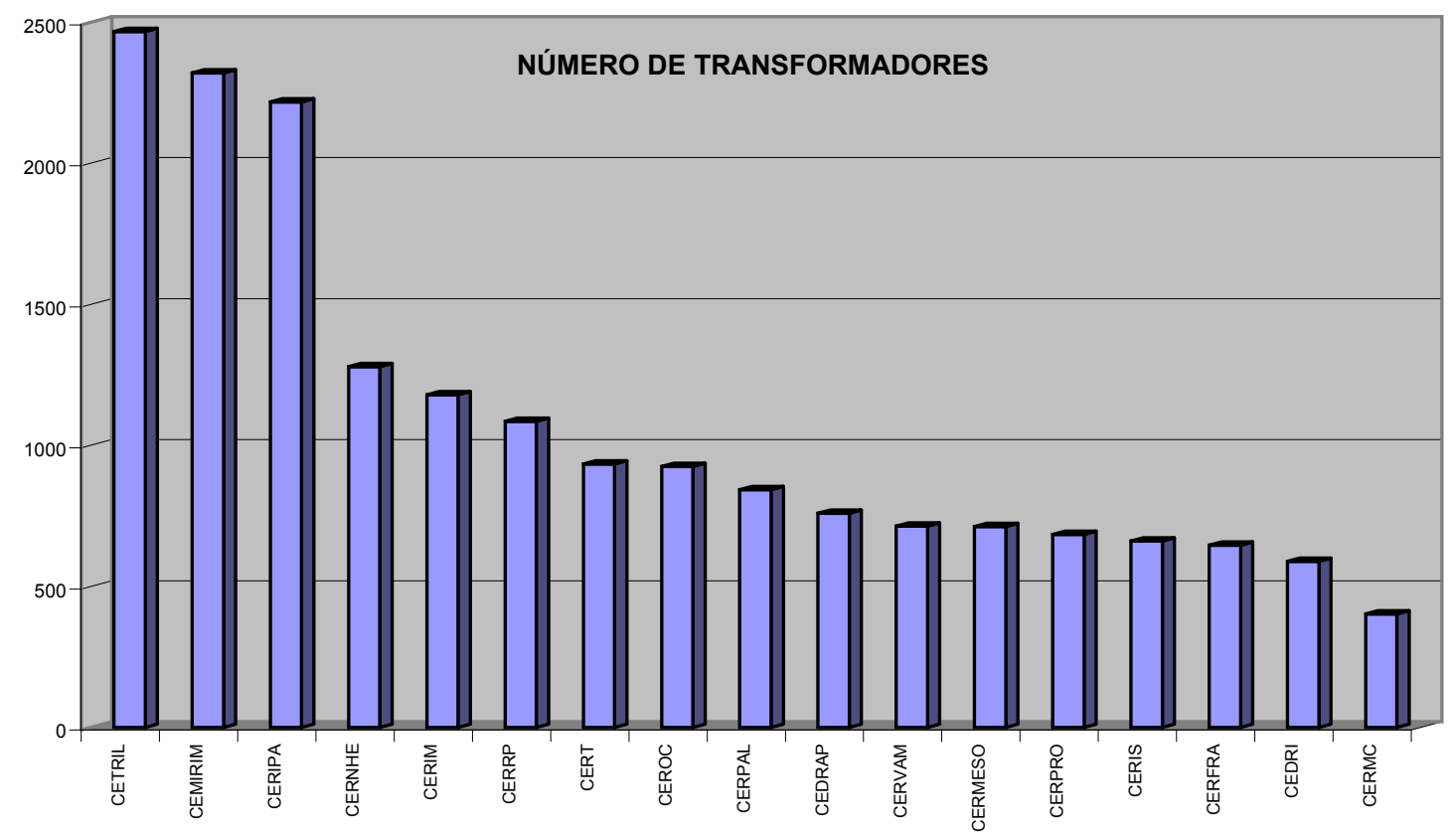

Fonte: $C S P E$

Figura 6.4-Comparativo entre a potência instalada das cooperativas

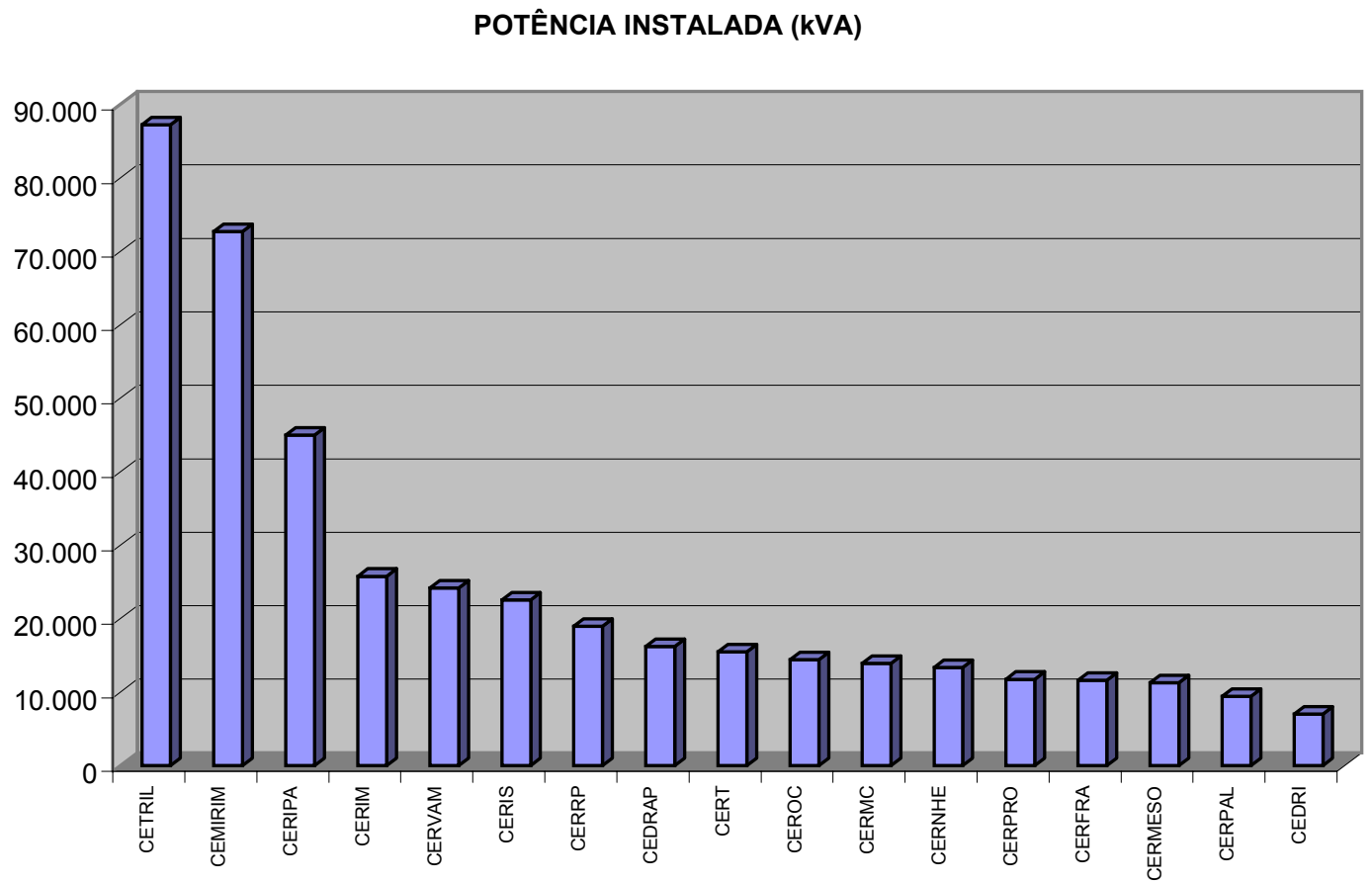

Fonte: CSPE 


\subsection{Dados do mercado das cooperativas de São Paulo}

Os principais dados do mercado das cooperativas de São Paulo são mostrados na Tabela 6.3 e nas Figuras 6.5, 6.6 e 6.7. Os dados se referem ao ano de 2001, exceto quando indicado. Da mesma forma que os dados físicos, são valores informados pelas cooperativas, sem posterior verificação, podendo conter erros. Como a classificação de consumidores rurais e urbanos não é a determinada pela Resolução Aneel 456/00 e há diferentes interpretações por parte das cooperativas, estes dados são suscetíveis a erro.

Tabela 6.3 - Dados do Mercado das cooperativas de São Paulo

\begin{tabular}{|l|c|c|c|c|c|c|c|c|}
\hline Cooperativa & $\begin{array}{c}\text { Demanda } \\
\text { Média } \\
\mathbf{2 0 0 1} \\
\mathbf{( M W )}\end{array}$ & $\begin{array}{c}\text { Energia } \\
\text { Adquirida } \\
\mathbf{2 0 0 1} \\
\mathbf{( G W h )}\end{array}$ & $\begin{array}{c}\text { Energia } \\
\text { Distribuída } \\
\mathbf{2 0 0 1} \\
\mathbf{( G W h )}\end{array}$ & $\begin{array}{c}\text { Número de } \\
\text { municípios } \\
\text { atendidos } \\
\text { (julho/99) }\end{array}$ & $\begin{array}{c}\text { Número de } \\
\text { consumi- } \\
\text { dores rurais } \\
\mathbf{( 1 2 / 2 0 0 1 )}\end{array}$ & $\begin{array}{c}\text { Número de } \\
\text { consumi- } \\
\text { dores } \\
\text { urbanos } \\
\text { (12/2001) }\end{array}$ & $\begin{array}{c}\text { Número } \\
\text { total de } \\
\text { consumi- } \\
\text { dores }\end{array}$ & $\begin{array}{c}\text { Potencial } \\
\text { de novas } \\
\text { ligações } \\
\mathbf{( 1 9 9 8 )}\end{array}$ \\
\hline CEDRAP & $2,56(1998)$ & 10,05 & 8,01 & 4 & 1.938 & 0 & 1.938 & 440 \\
\hline CEDRI & 0,70 & 5,86 & 4,47 & 4 & 1.369 & 263 & 1.632 & 1.955 \\
\hline CEMIRIM & 17,13 & 79,04 & 68,77 & 13 & 3.433 & 1.641 & 5.074 & 2.790 \\
\hline CERFRA & 1,45 & 4,45 & 4,00 & 9 & 689 & 0 & 689 & 213 \\
\hline CERIM & 6,19 & 23,75 & 19,84 & 7 & 4.963 & 0 & 4.963 & 248 \\
\hline CERIPA & 21,39 & 58,26 & 53,26 & 7 & 1.681 & 2.677 & 4.358 & 4.481 \\
\hline CERIS & 2,74 & 10,46 & 9,42 & 5 & 2.143 & 1.063 & 3.206 & N/D \\
\hline CERMC & 4,42 & 15,32 & 14,99 & 2 & 625 & 875 & 1.500 & 0 \\
\hline CERMESO & 2,07 & 7,96 & 4,65 & 7 & 930 & 0 & 930 & N/D \\
\hline CERNHE & 2,16 & 7,49 & 6,34 & 5 & 1.370 & 0 & 1.370 & 770 \\
\hline CEROC & 2,22 & 5,81 & 4,50 & 10 & 1.463 & 0 & 1.463 & N/D \\
\hline CERPAL & 1,08 & 4,35 & 3,14 & 8 & 867 & 0 & 867 & N/D \\
\hline CERPRO & 1,69 & 7,15 & 6,25 & 6 & 1.083 & 0 & 1.083 & 356 \\
\hline CERRP & $2,35(1998)$ & 11,31 & 9,74 & 13 & 2.775 & 0 & 2.775 & 4.125 \\
\hline CERT & 2,08 & 22,27 & 6,45 & 4 & 1.389 & 628 & 2.017 & 146 \\
\hline CERVAM & 5,18 & 7,79 & 20,01 & 6 & 1.187 & 85 & 1.272 & 370 \\
\hline CETRIL & 14,88 & 41,94 & 37,12 & 3 & 10.851 & 0 & 10.851 & 1.280 \\
\hline Total & 85,39 & 323,27 & 280,98 & 113 & 38.756 & 7.232 & 45.988 & 17.174 \\
\hline FER & & & & & & & \\
\hline
\end{tabular}


Figura 6.5 - Comparativo da demanda média das cooperativas

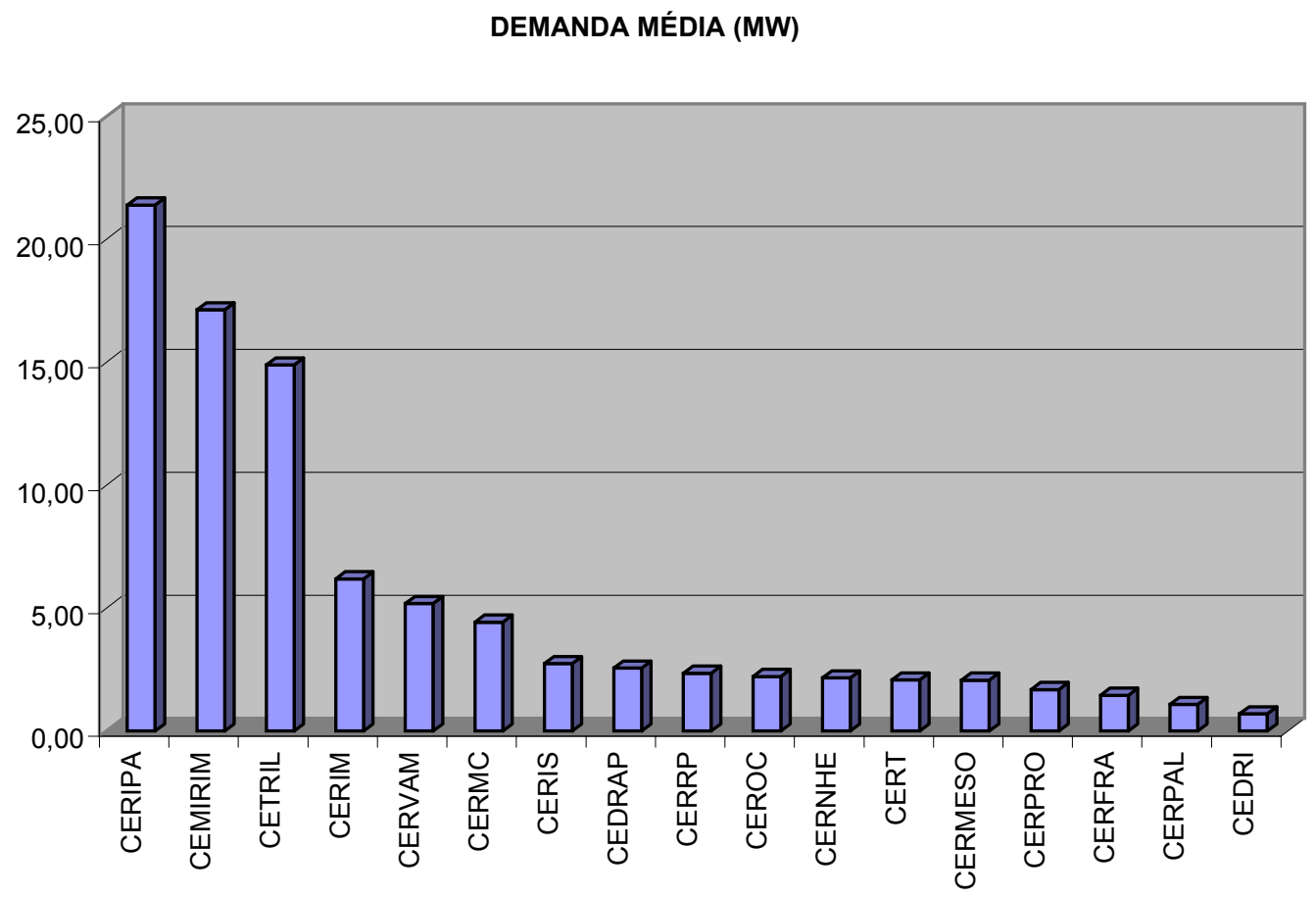

Fonte: CSPE

Figura 6.6 - Comparativo da energia distribuída das cooperativas

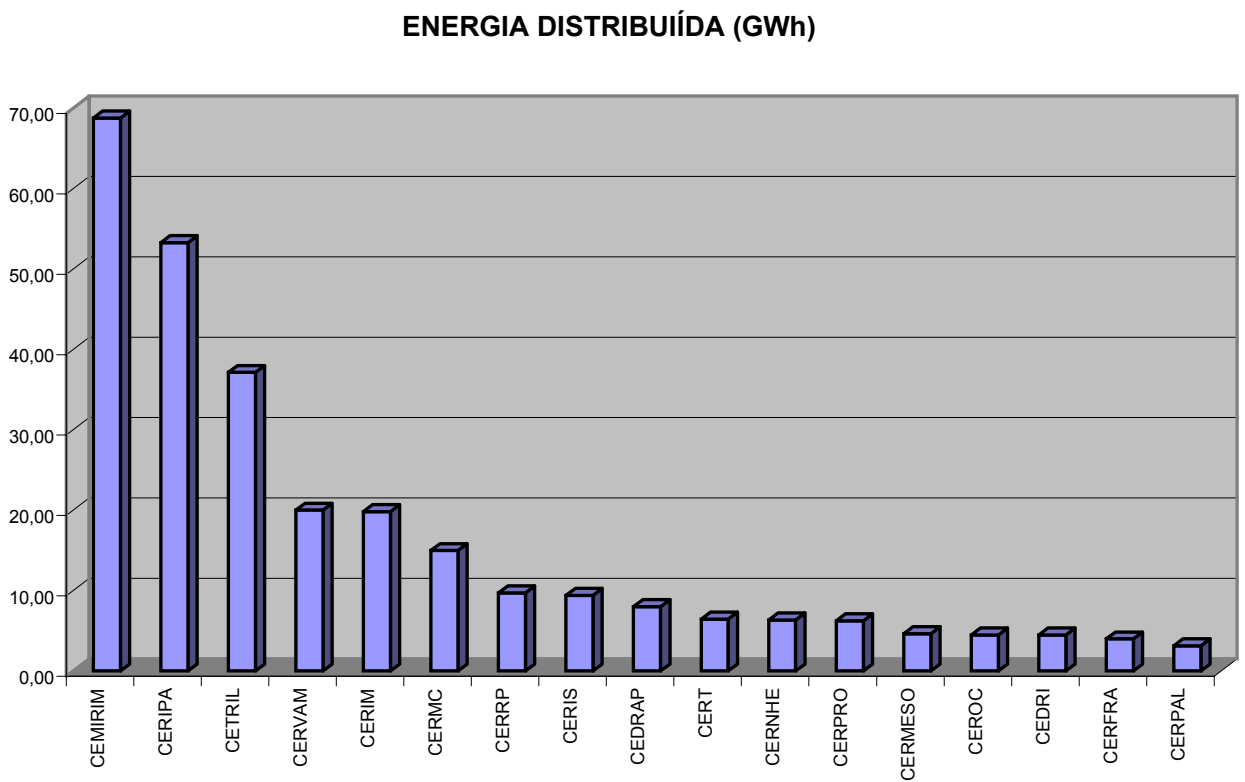


Figura 6.7 - Comparativo do número de consumidores das cooperativas

NÚMERO DE CONSUMIDORES

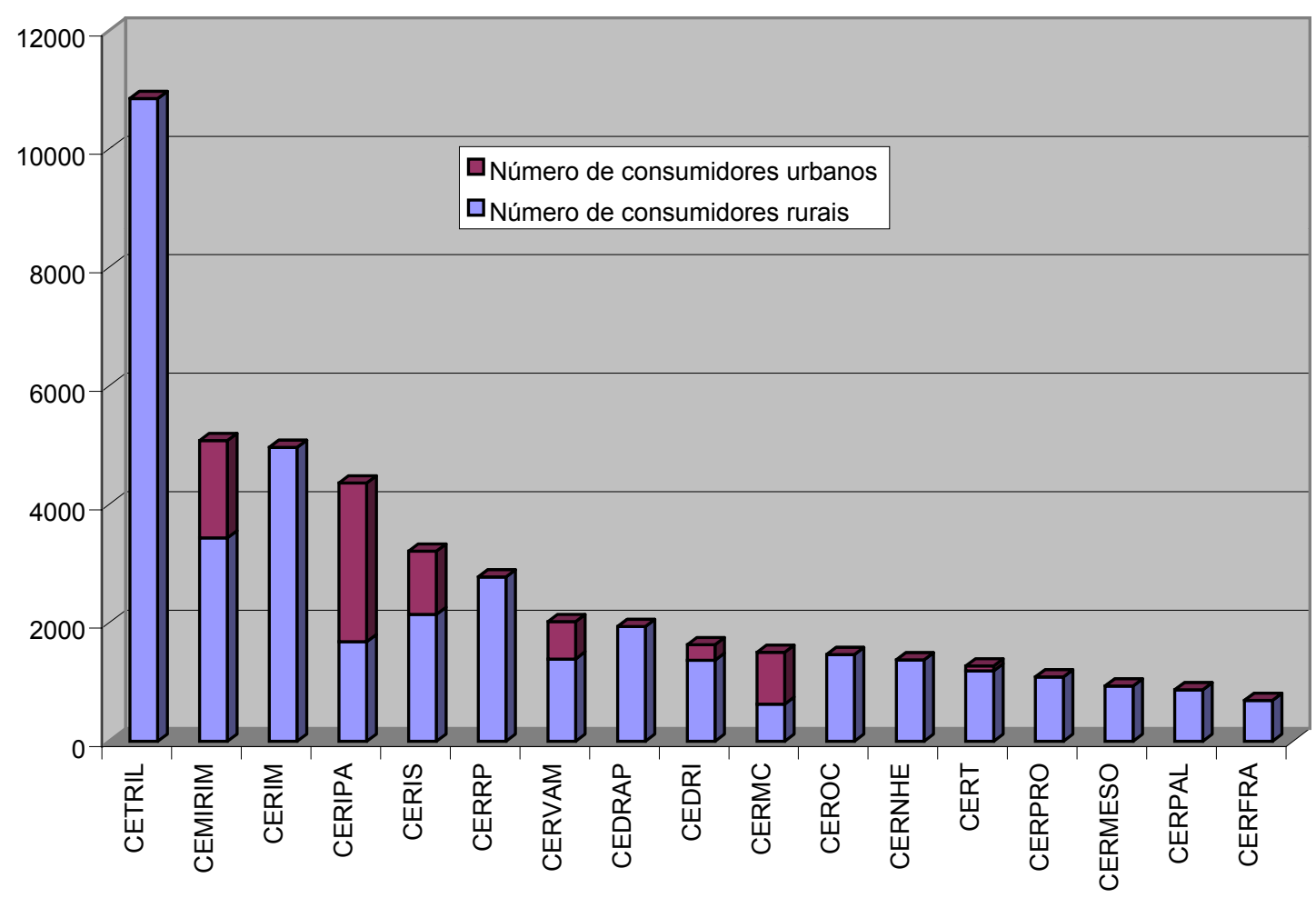

Fonte: CSPE

Os dados a respeito do faturamento das cooperativas de eletrificação rural de São Paulo são mostrados na Tabela 6.4 e na Figura 6.8, e se referem ao ano de 2001. 
Tabela 6.3 - Dados de Faturamento das cooperativas de São Paulo

\begin{tabular}{|l|r|r|r|}
\hline \multirow{2}{*}{ Cooperativa } & \multirow{2}{*}{$\begin{array}{c}\text { Faturamento } \\
\text { (R\$) }\end{array}$} & \multicolumn{1}{|c|}{ Energia Distribuida } \\
\cline { 4 - 4 } & & \multicolumn{1}{c|}{ MWh } & $\begin{array}{c}\text { Custo Médio } \\
\text { (R\$/MWh) }\end{array}$ \\
\hline CEDRAP & $1.939 .288,00$ & 8.009 & 242,13 \\
\hline CEDRI & $716.823,00$ & 4.472 & 160,30 \\
\hline CEMIRIM & $9.536 .575,00$ & 68.773 & 138,67 \\
\hline CERFRA & $919.286,00$ & 4.000 & 229,84 \\
\hline CERIM & $4.428 .511,00$ & 19.837 & 223,24 \\
\hline CERIPA & $8.439 .184,00$ & 53.263 & 158,44 \\
\hline CERIS & $2.053 .065,00$ & 9.419 & 217,97 \\
\hline CERMC & $1.949 .546,00$ & 14.991 & 130,05 \\
\hline CERMESO & $1.118 .745,00$ & 4.650 & 240,57 \\
\hline CERNHE & $1.156 .129,00$ & 6.341 & 182,34 \\
\hline CEROC & $1.292 .958,00$ & 4.505 & 287,03 \\
\hline CERPAL & $753.414,00$ & 3.143 & 239,74 \\
\hline CERPRO & $1.337 .398,00$ & 6.248 & 214,06 \\
\hline CERRP & $1.973 .968,00$ & 9.743 & 202,60 \\
\hline CERVAM & $3.379 .423,00$ & 20.015 & 168,84 \\
\hline CERT & $1.442 .537,00$ & 6.452 & 223,57 \\
\hline CETRIL & $7.770 .172,00$ & 37.123 & 209,31 \\
\hline Total & $50.207 .022,00$ & 280.983 & 178,68 \\
\hline Fonte: CSPE. & & &
\end{tabular}

Figura 6.8 - Comparativo do número de consumidores das cooperativas

FATURAMENTO (R\$)

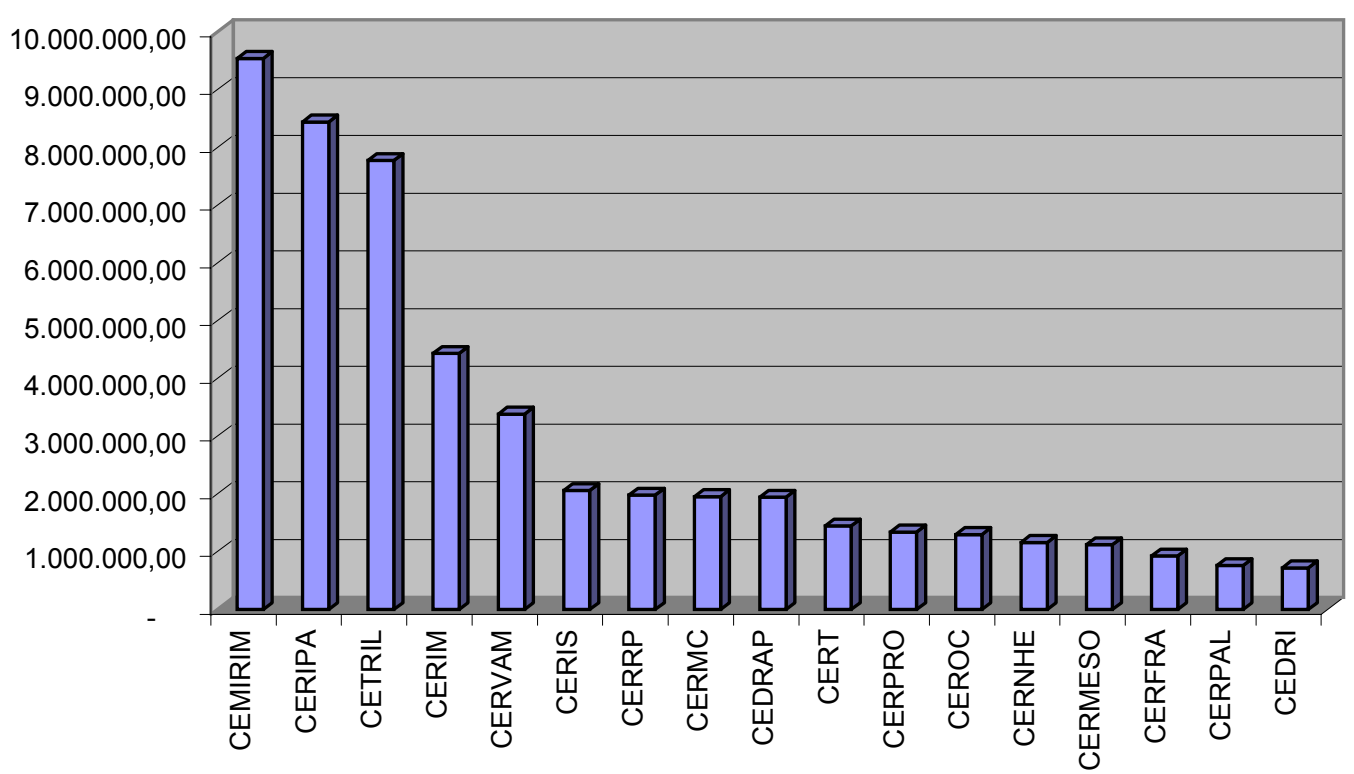




\subsection{Detalhamento do mercado atendido}

Os itens a seguir detalham, para cada cooperativa, aspectos em relação ao mercado atendido. Procurou-se interpretar, de acordo com a classificação de consumidores adotada por cada uma delas, como está dividido o mercado por classe de consumidores e localização geográfica.

\subsection{1-CEDRAP}

A CEDRAP - Cooperativa de Eletrificação e Desenvolvimento Rural do Alto Paraíba atende cooperados e consumidores nos municípios de Paraibuna, Santa Branca, Jambeiro e São José dos Campos, e é suprida através de 5 pontos de conexão, pelas concessionárias Bandeirante Energia S.A. e Elektro - Eletricidade e Serviços S.A.

De acordo com os dados de mercado obtidos em 2000, verifica-se que a CEDRAP tem $100 \%$ dos seus consumidores situados na área rural. A maioria dos consumidores faz parte da classe rural agropecuária (51\%), seguida pela classe residencial (42\%). Também há uma pequena participação de outras classes: comercial e serviços $(6 \%)$ e industrial e poder público $(1 \%)$. O consumo se dá mais na classe rural agropecuária (49\%). Em seguida vem a classe comercial e de serviços, responsável por $27,5 \%$ do consumo da Cooperativa. A classe residencial consome $22 \%$ e as classes industrial e poder público respondem pelo restante (cerca de $1,5 \%)$.

\subsection{2-CEDRI}

A CEDRI - Cooperativa de Energização e Desenvolvimento Rural do Vale do Itariri atende cooperados e consumidores nos municípios de Itariri, Pedro de Toledo, Peruíbe e Itanhaém. É suprida através de 4 pontos de conexão pela concessionária Elektro - Eletricidade e Serviços S. A.

De acordo com os dados de mercado da CEDRI todos os seus consumidores são cooperados e localizam-se na área rural e quase todos são da classe rural (cerca 
de $99 \%$ ), divididos entre as classes rural agropecuária (74,61\%) e rural coletividade $(24,23 \%)$. O restante $(1 \%)$ se divide entre as classes comercial e serviços, poder público e serviço público. Também o consumo ocorre quase todo entre os consumidores de classe rural (99\%), sendo a classe rural agropecuária responsável pela maior parte $(83 \%)$ enquanto que a classe rural coletividade responde por cerca de $16 \%$ do consumo. As demais classes são responsáveis pelo consumo restante (cerca de 1\%).

\subsection{3 - CEMIRIM}

A CEMIRIM - Cooperativa de Eletrificação e Desenvolvimento Rural da Região de Mogi Mirim, atende cooperados e consumidores nos municípios de Aguaí, Artur Nogueira, Conchal, Cosmópolis, Engenheiro Coelho, Espírito Santo do Pinhal, Estiva Gerbi, Holambra, Itapira, Jaguariúna, Mogi Guaçu, Mogi Mirim e Santo Antonio de Posse. É suprida através de 9 pontos de conexão pelas concessionárias Elektro Eletricidade e Serviços S. A. (7), Companhia Paulista de Força e Luz (1) e Companhia Jaguari de Energia (1).

Os dados de mercado da CEMIRIM indicam que ela possui aproximadamente $44 \%$ de seus consumidores na classe residencial, mas que representam $12 \%$ do consumo total de energia. A classe rural agropecuária representa $49 \%$ do número total de consumidores que consomem $53 \%$ da energia vendida. Os demais consumidores estão distribuídos do seguinte modo: comércio/serviços (5\%) com consumo de $7 \%$, industrial (1\%) com consumo de $26 \%$, serviço público, poder público e iluminação pública (1\%) com consumo de $2 \%$. A Cooperativa possui $72 \%$ de seus consumidores localizados na área rural e $28 \%$ na área urbana, sendo $63 \%$ consumidores cooperados e $27 \%$ não associados à Cooperativa. A Cooperativa possui $53 \%$ de seus consumidores enquadrados em classes de consumo não-rurais e vende $47 \%$ do total de sua energia para esses consumidores.

\section{$6.4 .4-C E R F R A$}

A CERFRA - Cooperativa de Eletrificação e Desenvolvimento da Região de Franca atende consumidores nos municípios de Franca, São José da Bela Vista, 
Patrocínio Paulista, Ribeirão Corrente, Ituverava, Guará, e Jeriquara. Atende também, no estado de Minas Gerais, consumidores do município de Ibiraci. É suprida através de 4 pontos de conexão, pela Companhia Paulista de Força e Luz.

Pelos dados de mercado da CERFRA verifica-se que a maioria dos consumidores da CERFRA é cooperado (95,5\%). Cerca de $22 \%$ são considerados, pela cooperativa, como urbanos, mas residem em vilarejos rurais. A classe rural agropecuária corresponde a $75 \%$ dos consumidores e responde por aproximadamente $80 \%$ da energia total consumida. A classe residencial é composta por cerca de $20 \%$ dos clientes da cooperativa, e é responsável por $10 \%$ do consumo de energia. $77 \%$ dos consumidores pertencem a classe rural e representam $86 \%$ do mercado de energia. Os consumidores das classes não rurais correspondem a $23 \%$ do mercado da cooperativa e consomem $14 \%$ da energia comercializada.

\section{$6.4 .5-C E R I M$}

A CERIM - Cooperativa Agrícola Mista e de Eletrificação Rural ItuMairinque atende cooperados nos municípios de Alumínio, Araçariguama, Cabreúva, Itu, Mairinque, São Roque e Sorocaba, e é suprida através de 2 pontos de conexão pela CPFL - Piratininga.

Segundo os dados de mercado da CERIM, verifica-se que a CERIM possui quase a totalidade de seus consumidores na classe residencial $(96 \%)$ e os demais consumidores estão distribuídos nas classes: rural agropecuária (2\%), comércio/indústria (1\%) e serviço público (1\%). Quanto ao consumo de energia, também se verifica que a classe residencial é a mais representativa (78\%), porém o consumo de energia é maior na classe comercial/industrial $(14 \%)$ em relação à classe rural agropecuária (7\%). Todos os consumidores estão localizados na área rural e são associados à Cooperativa. A Cooperativa possui $98 \%$ dos consumidores enquadrados na classe de consumo não rurais e vende $93 \%$ de sua energia para esses consumidores. 


\subsection{6-CERIPA}

A CERIPA - Cooperativa de Eletrificação Rural de Itaí-Paranapanema-Avaré atende cooperados e consumidores nos municípios de Itaí, Paranapanema, Avaré, Taquarituba, Arandu, Itatinga, Coronel Macedo, Itaberá, Itapeva e Buri. É suprida através de 14 pontos de conexão, pelas concessionárias Elektro (5 pontos) e Santa Cruz ( 9 pontos).

Pelos dados de mercado da CERIPA, verifica-se que ela possui mais de $50 \%$ de seus consumidores na classe residencial, mas que representam menos de $20 \%$ do consumo total da energia. Por outro lado, as subclasses rural agropecuária e irrigação, que representam $43 \%$ do número total de consumidores, consomem mais de $60 \%$ da energia vendida. Tal fato se deve à característica da classe rural-irrigação, que representa em torno de $5 \%$ do número de consumidores, mas consome mais de $30 \%$ do total de energia da Cooperativa. Verifica-se também que a CERIPA tem 43 $\%$ dos seus consumidores situados na área urbana; e $45 \%$ dos consumidores não são cooperados, caracterizando o atendimento comercial desses consumidores. A cooperativa possui $57 \%$ de seus consumidores enquadrados em classes de consumo não-rurais e vende $35 \%$ do total de sua energia para esses consumidores.

\subsection{7-CERIS}

A CERIS - Cooperativa de Eletrificação Rural da Região de Itapecerica da Serra atende consumidores nos municípios de Embu-Guaçu, Itapecerica da Serra, São Lourenço da Serra, Juquitiba e São Paulo. A cooperativa é suprida através de 7 pontos de conexão, pela concessionária Eletropaulo Metropolitana S.A.

Segundo os dados de mercado fornecidos pela CERIS, aproximadamente $20 \%$ dos consumidores da CERIS são não-cooperados. Cerca de $24 \%$ dos clientes da Cooperativa residem em áreas urbanas e $92 \%$ deles pertencem a classes distintas da rural. A classe rural consome apenas $17 \%$ da energia distribuída, ficando o restante para as demais classes.

Os consumidores residenciais correspondem a mais de $60 \%$ do mercado da Cooperativa e respondem por $57 \%$ do consumo total de energia. A classe residencial 
de baixa renda representa $27 \%$ dos consumidores e é responsável pelo consumo de aproximadamente $14 \%$ da energia distribuída. Os clientes residenciais rurais somam $7,5 \%$ do público atendido e consomem $13 \%$ da energia comercializada pela CERIS.

\subsection{8-CERMC}

A CERMC - Cooperativa de Eletrificação Rural de Mogi das Cruzes atende consumidores e cooperados nos municípios de Mogi das Cruzes e Suzano, e é suprida através de 6 pontos de conexão, pela concessionária Bandeirante Energia.

Pelos dados de mercado da CERMC, verifica-se que todos os seus consumidores são cooperados. Cerca de $50 \%$ deles correspondem à classe residencial, mas representam um consumo inferior a $10 \%$ do total da energia. Por outro lado, a subclasse industrial, que corresponde a $0,2 \%$ do total de cooperados, responde por mais de $50 \%$ da energia consumida. A subclasse rural agropecuária que representa cerca de 40\% dos consumidores da CERMC é responsável por aproximadamente $30 \%$ do consumo de energia. Verifica-se também que $56 \%$ dos consumidores da CERMC são urbanos e 58\% pertencem a classe de consumo nãorurais. Cerca de $70 \%$ do total da energia distribuída pela CERMC é vendida para consumidores enquadrados em classes de consumo não-rurais.

\subsection{9-CERNHE}

A CERNHE - Cooperativa de Energização e Desenvolvimento Rural de Novo Horizonte atende consumidores nos municípios de Novo Horizonte, Itajobi, Borborema, Marapuãma, Elizário, Catanduva, Tabapuã, Novaes e Urupês, e é suprida através de 4 pontos de conexão, pela Companhia Nacional de Energia Elétrica.

Os dados de mercado da CERNHE indicam que todos os consumidores são cooperados e residem em áreas rurais. Aproximadamente $20 \%$ dos consumidores da Cooperativa são residenciais e respondem por $8,5 \%$ do consumo de energia. $24 \%$ dos clientes pertencem a classes de consumo não-rurais e correspondem a $13 \%$ do mercado de energia elétrica. Os consumidores das classes rurais correspondem a $76 \%$ do mercado da CERNHE e consomem $87 \%$ da energia comercializada. 


\subsubsection{0-CERPRO}

A CERPRO - Cooperativa de Eletrificação Rural da Região de Promissão atende cooperados nos municípios de Promissão, Guaiçara, Avanhandava, Alto Alegre, Braúna e Clementina. É suprida através de 5 pontos de conexão pela concessionária CPFL - Companhia Paulista de Força e Luz.

Pelos dados de mercado da CERPRO, verifica-se que a maior parte de seus consumidores está na classe rural agropecuária $(79,45 \%)$ e os demais consumidores estão distribuídos nas classes: rural coletividade (13,64\%), comercial/serviços $(5,63 \%)$, industrial $(0,99 \%)$ e rural irrigação, poder público e iluminação pública com $0,10 \%$ cada. Quanto ao consumo de energia, também se verifica que a classe rural agropecuária é a mais representativa (65,54\%), seguida das classes industrial $(11,13 \%)$, comercial/ serviços $(10,37 \%)$, poder público $(8,37 \%)$, rural coletividade $(3,83 \%)$, iluminação pública $(1,48 \%)$ e rural irrigação $(0,28 \%)$. Verifica-se que a CERPRO possui $14 \%$ dos seus consumidores situados na área urbana $13 \%$ dos consumidores não são cooperados, caracterizando o atendimento comercial desses consumidores. A cooperativa possui $20 \%$ de seus consumidores enquadrados em classes de consumo não rurais e vende $35 \%$ do total de sua energia para esses consumidores.

\subsubsection{1-CERRP}

A CERRP - Cooperativa de Eletrificação Rural da Região de São José do Rio Preto atende cooperados nos municípios de Palmital, Ibirarema, Platina, Ribeirão do Sul, Cândido Mota, Echaporã, Salto Grande e Campos Novos Paulista. A CERRP é suprida através de 7 pontos de conexão pelas concessionárias Companhia Paulista de Força e Luz (5 pontos) e Companhia Nacional de Energia Elétrica (2 pontos).

Os dados de mercado da CERRP indicam que a cooperativa possui aproximadamente $50 \%$ de seus consumidores na classe residencial, mas que representam $15 \%$ do consumo total de energia. A classe rural agropecuária representa $46 \%$ do número total de consumidores que consomem $52 \%$ da energia vendida. Os demais consumidores estão distribuídos do seguinte modo: 
comércio/serviços $(3 \%)$ com consumo de $14 \%$, industrial $(0,2 \%)$ com consumo de $14 \%$, rural irrigação e rural coletividade $(0,13 \%)$ com consumo de $5 \%$. Todos os consumidores estão localizados na área rural e são associados à Cooperativa. A Cooperativa possui $54 \%$ de seus consumidores enquadrados em classes de consumo não-rurais e vende $43 \%$ do total de sua energia para esses consumidores.

\section{$6.4 .12-C E R V A M$}

A CERVAM - Cooperativa de Energização e de Desenvolvimento Rural do Vale do Mogi atende cooperados e consumidores nos municípios de Porto Ferreira, Pirassununga, Descalvado, Santa Cruz das Palmeiras, Santa Rita do Passa Quatro e Aguaí. A cooperativa é suprida através de 5 pontos de conexão pelas concessionárias Companhia Paulista de Força e Luz e Elektro - Eletricidade e Serviços S.A.

Segundo os dados de mercado apresentados pela CERVAM, 69\% dos seus consumidores estão situados na área urbana, 27\% dos seus consumidores nãocooperados, caracterizando o atendimento comercial desses consumidores. Também, possui $64 \%$ dos seus consumidores enquadrados em classes de consumo não-rurais e vende $72 \%$ do total de sua energia para consumidores enquadrados em classes de consumo não-rurais.

\section{$6.4 .13-$ CETRIL}

A CETRIL - Cooperativa de Eletrificação e Telefonia Rurais de Ibiúna atende cooperados nos municípios de Ibiúna e Piedade, e é suprida através de 3 pontos de conexão, pelas concessionárias CPFL - Piratininga e Elektro Eletricidade e Serviços S.A.

Pelos dados de mercado da CETRIL, todos os seus consumidores são cooperados e localizam-se em áreas rurais. Cerca de 90\% deles correspondem à classe residencial e respondem por aproximadamente $70 \%$ da energia total consumida. A classe rural irrigação representa $2 \%$ do total de consumidores e consome cerca de $16 \%$ da energia distirubuída pela cooperativa. As demais classes correspondem a $18 \%$ dos consumidores e possuem um consumo de cerca de $24 \%$ do 
total. Os consumidores classificados em classes de consumo não rurais representam $95 \%$ do mercado da cooperativa e consomem $80 \%$ da energia comercializada.

$$
\text { 6.4.14-CERMESO }
$$

A CERMESO - Cooperativa de Eletrificação Rural da Média Sorocabana atende cooperados e consumidores nos municípios de Águas de Santa Barbára, Arandu, Bernardino Campos, Cerqueira César, Manduri, Óleo e Piraju. A CERMESO é suprida através de 2 pontos de conexão, pela Companhia Luz e Força Santa Cruz.

Os dados de mercado apresentados pela CERMESO permitem verificar que todos os consumidores são cooperados e estão na área rural. A classe rural consome $100 \%$ do total da energia vendida.

\subsubsection{5-CERPAL}

A CERPAL - Cooperativa de Eletrificação Rural da Região de Palmital atende cooperados nos municípios de Palmital, Ibirarema, Platina, Ribeirão do Sul, Cândido Mota, Echaporã, Salto Grande e Campos Novos Paulista. Ela é é suprida através de 1 ponto de conexão pela concessionária Empresa de Eletricidade Vale do Paranapanema S.A.

Pelos dados de mercado da CERPAL, a totalidade de seus consumidores são da classe rural distribuídos do seguinte modo: rural agropecuária $(98,2 \%)$, industrial $(0,3 \%)$ e comércio $(1,5 \%)$. Quanto ao consumo de energia, também se verifica que a classe rural agropecuária é a mais representativa $(95,4 \%)$, seguida pela classe comercial $(3,1 \%)$ e finalmente a classe industrial $(1,5 \%)$. Todos os consumidores estão localizados na área rural e são associados à Cooperativa.

\section{$6.4 .16-C E R O C$}

A CEROC - Cooperativa de Eletrificação Rural da Região de Osvaldo Cruz atende cooperados e consumidores nos municípios de Osvaldo Cruz, Parapuã, Rinópolis, Salmourão, Lucélia, Inúbia Paulista, Adamantina, Sagres e Pracinha. A 
CEROC é suprida através de 4 pontos de conexão pela concessionária Caiuá Serviços de Eletricidade S.A.

Pelos dados de mercado apresentados pela CEROC, verifica-se que 98\% de seus consumidores estão enquadrados na classe rural, representando $86 \%$ da energia total distribuída. Todos os seus consumidores são cooperados e se localizam na área rural. A cooperativa estima que ainda haja 1.168 propriedades ainda não eletrificadas em sua área de atuação.

\subsubsection{7-CERT}

A CERT - Cooperativa de Eletrificação Rural da Região de Tupã atende cooperados e consumidores nos municípios de Tupã, Bastos, Arco-Íris, Iacri e Rinópolis, e é suprida através de 3 pontos de conexão pela Empresa de Eletricidade Vale do Paranapanema.

Os dados de mercado da CERT permitem verificar que a grande maioria dos consumidores $(91 \%)$ se enquadra na classe rural (rural agropecuária, rural irrigação e, principalmente, rural coletividade). Também, o consumo dos consumidores rurais corresponde a $87 \%$ da energia vendida pela Cooperativa. Os demais consumidores, cerca de 9\%, se enquadram nas classes: residencial, industrial, comercial, serviço público, poder público e iluminação pública, sendo responsáveis por $8 \%$ do consumo da energia vendida pela CERT. Todos os consumidores da CERT são cooperados e localizam-se na área rural. 


\section{CAPÍTULO 7 - O DIAGNÓSTICO DAS COOPERATIVAS DE ELETRIFICAÇÃO RURAL PAULISTAS}

\subsection{Análise quantitativa dos dados}

Os dados obtidos na pesquisa permitiram a observação de alguns aspectos, em relação ao conjunto das cooperativas de São Paulo:

- As 17 cooperativas atendem a quase 46.000 consumidores, faturando em torno de $\mathrm{R} \$$ 50,2 milhões/ano. O faturamento máximo é da Cemirim, de R 9,53 milhões e o faturamento mínimo é de R\$ 0,71 milhões, da Cedri.

- Há grande variação no custo médio da energia distribuída pelas cooperativas, de $\mathrm{R} \$ 130,05 / \mathrm{MWh}$ (Cermc) a R\$ 287,03/MWh (Ceroc). O custo médio ponderado da energia é de R\$178,68/MWh. Em geral, quanto menor o porte da cooperativa mais alto é este custo.

- Há um grupo de três cooperativas (Cetril, Cemirim e Ceripa) que concentram os maiores números. O conjunto das três é responsável por aproximadamente $54 \%$ do faturamento total, $44 \%$ do número de consumidores e $57 \%$ da energia vendida pelo total de cooperativas do estado.

- Pode-se, a grosso modo, realizar uma divisão das cooperativas em três grupos: as grandes (Cetril, Cemirim e Ceripa), as médias (Cerim, Cervam, Cermc, Cerrp e Ceris) e as pequenas (Cert, Ceroc, Cedri, Cedrap, Cermeso, Cerpro, Cernhe, Cerpal, Cerfra). A figura 7.1, comparando municípios atendidos, energia vendia e número de consumidores, procura ilustrar esse fato. 
Figura 7.1 - Comparativo: Energia vendida x Consumidores das cooperativas

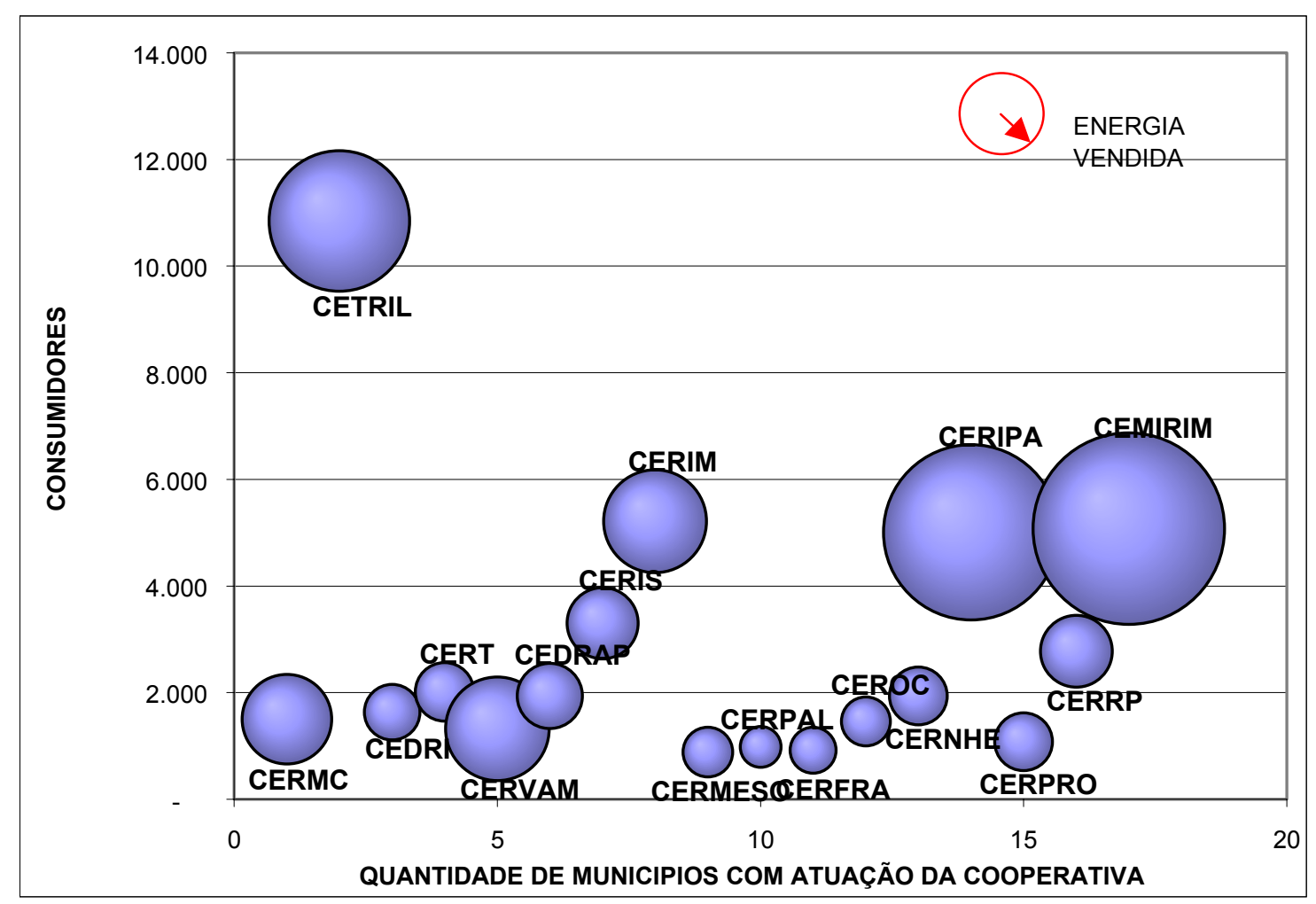

Fonte: CSPE, 2001

- Constata-se que entre as cooperativas há uma razoável disparidade nos índices técnicos, conforme se pode verificar na Tabela 7.1: 
Tabela 7.1 - Índices técnicos das cooperativas de São Paulo

\begin{tabular}{|l|r|r|r|r|r|r|r|r|}
\hline Cooperativa & $\begin{array}{r}\text { Cons./ } \\
\text { km_rede }\end{array}$ & $\begin{array}{c}\mathbf{R} \mathbf{\$} \text { / } \\
\text { km_rede }\end{array}$ & $\begin{array}{c}\text { Potência } \\
\text { instalada } \\
\text { / km rede }\end{array}$ & $\begin{array}{r}\text { Cons/ } \\
\text { transformador }\end{array}$ & $\begin{array}{c}\text { Potência } \\
\text { instalada } \\
\text { / Cons. }\end{array}$ & $\begin{array}{c}\text { kWhano/ } \\
\text { Cons. }\end{array}$ & $\begin{array}{c}\text { Demanda } \\
\text { Média/ Cons. } \\
\text { (kW/cons) }\end{array}$ & $\begin{array}{c}\text { Perdas } \\
\text { Totais }\end{array}$ \\
\hline CEDRAP & 2,78 & $2.782,34$ & 23,31 & 2,55 & 8,38 & 4132,81 & 1,32 & $20,3 \%$ \\
\hline CEDRI & 2,77 & $1.217,02$ & 11,94 & 2,77 & 4,31 & 2740,04 & 0,43 & $23,7 \%$ \\
\hline CEMIRIM & 4,57 & $8.583,78$ & 65,45 & 2,19 & 14,33 & 13554,00 & 3,38 & $13,0 \%$ \\
\hline CERFRA & 1,66 & $2.209,82$ & 27,91 & 1,06 & 16,85 & 5805,09 & 2,11 & $10,0 \%$ \\
\hline CERIM & 6,35 & $5.663,06$ & 32,98 & 4,21 & 5,20 & 3997,04 & 1,25 & $16,5 \%$ \\
\hline CERIPA & 2,43 & $4.701,50$ & 25,07 & 1,96 & 10,33 & 12221,89 & 4,91 & $8,6 \%$ \\
\hline CERIS & 7,78 & $4.983,17$ & 54,81 & 4,85 & 7,04 & 2937,88 & 0,86 & $10,0 \%$ \\
\hline CERMC & 7,32 & $9.509,98$ & 67,93 & 3,72 & 9,28 & 9993,91 & 2,95 & $2,1 \%$ \\
\hline CERMESO & 1,54 & $1.855,30$ & 18,75 & 1,30 & 12,16 & 5000,44 & 2,23 & $41,6 \%$ \\
\hline CERNHE & 1,43 & $1.208,08$ & 13,96 & 1,07 & 9,75 & 4628,22 & 1,58 & $15,4 \%$ \\
\hline CEROC & 1,99 & $1.759,13$ & 19,67 & 1,58 & 9,88 & 3079,00 & 1,52 & $22,5 \%$ \\
\hline CERPAL & 1,33 & $1.159,10$ & 14,54 & 1,03 & 10,90 & 3624,78 & 1,25 & $27,8 \%$ \\
\hline CERPRO & 2,04 & $2.513,91$ & 22,13 & 1,58 & 10,87 & 5769,05 & 1,56 & $12,6 \%$ \\
\hline CERRP & 4,31 & $3.065,17$ & 29,48 & 2,56 & 6,84 & 3511,08 & 0,85 & $13,9 \%$ \\
\hline CERVAM & 3,99 & $6.678,70$ & 47,77 & 2,82 & 11,98 & 9923,15 & 2,57 & $10,1 \%$ \\
\hline CERT & 1,75 & $1.989,71$ & 21,35 & 1,36 & 12,17 & 5072,44 & 1,63 & $17,1 \%$ \\
\hline CETRIL & 8,20 & $5.873,15$ & 65,92 & 4,40 & 8,04 & 3421,12 & 1,37 & $11,5 \%$ \\
\hline Média & $\mathbf{3 , 6 3}$ & $\mathbf{3 . 9 5 8 , 9 2}$ & $\mathbf{3 3 , 2 1}$ & $\mathbf{2 , 5 0}$ & $\mathbf{9 , 1 6}$ & $\mathbf{6 1 0 9 , 9 2}$ & $\mathbf{1 , 9 6}$ & $\mathbf{1 3 , 1 \%}$ \\
\hline
\end{tabular}

- Analisando estes índices, podemos verificar que a potência instalada por consumidor é alta e o número de consumidores por quilômetro de rede e por transformador é baixo, bem como a rentabilidade da rede. O índice de perdas é bastante grande. Os índices demonstram a existência, mesmo nas cooperativas maiores, de um mercado rural bem significativo.

- Esta análise permite inferir que, mesmo possuindo público indistinto, as cooperativas que se enquadram como permissionárias irão exigir um subsídio econômico, para manter o equilíbrio do futuro contrato de permissão, por causa principalmente do mercado atendido.

\subsection{Questões relativas ao serviço}

A análise dos relatórios de inspeção, da documentação enviada e os relatos dos inspetores permitiram apurar algumas questões importantes referentes à história e ao serviço prestado pelas cooperativas. 
Todas as cooperativas de São Paulo foram fundadas nas décadas de 60 e 70 . Os dirigentes, em grande parte, eram ou ficaram ligados à política local.

Esse traço continua até hoje em algumas cooperativas, e pode-se afirmar que é bem típico. O presidente de uma cooperativa é eleito pelos cooperados. É natural que o escolhido seja uma pessoa de forte liderança. Num município pequeno, onde muitas vezes a cooperativa é uma das maiores empresas, a sua influência acaba se estendendo também ao poder municipal.

Em alguns casos, essa influência acaba se estendendo por longo tempo. Há casos em que não houve troca na presidência desde a fundação da cooperativa, e outros onde os presidentes estavam há muitos anos no cargo.

Em Holambra, o primeiro prefeito era da direção da cooperativa e, findo o seu mandato, disputou e ganhou a presidência da Cemirim. O município de Holambra, aliás, é um grande exemplo de área de atuação definida sem serviço público regulado. Holambra é terra dos colonos holandeses que se dedicaram ao plantio de flores, hoje exportadas para toda a Europa, e que realiza a maior exposição de plantas do Brasil, a Expoflora.

O município foi criado na década de 80 , como desmembramento de outros três municípios, cada qual atendido por uma distribuidora diferente. Entretanto, a área do município não foi concedida a nenhum deles, pois o único agente que possui instalações de distribuição de energia é a Cemirim, surgida logo após a chegada dos primeiros colonos. O crescimento da colônia deu origem depois a Holambra II, no município de Paranapanema, juntamente com a cooperativa de eletrificação rural correspondente (Ceripa).

No momento da prorrogação das concessões, a Aneel reservou Holambra para atendimento da futura permissionária. Dessa forma, este passou a ser o único município do estado sem área concedida, embora também seja a única área demarcada oficialmente pelo órgão regulador para uma cooperativa. Há casos desse tipo, em maior número, também no Rio Grande do Sul. 
Em algumas ocasiões esta influência política pode atrapalhar. Segundo relatos colhidos junto à Fecoeresp, muitas das cooperativas extintas, além das causas ligadas à prestação do serviço, o foram também por divergências políticas internas ou entre os dirigentes da cooperativa e os poderes políticos locais.

As cooperativas de São Paulo, na época de sua implantação pelo DAEE, adotavam padrões inspirados no sistema americano, inovador para a época. Foi feito um grande trabalho para simplificar e adaptar padrões e procedimentos de projeto, de modo a tornar mais econômica a implantação das redes, adequando-se à demanda da carga e evitando superdimensionamentos. Assim, os recursos disponíveis poderiam atender a um maior número de pessoas.

Foram usados postes de madeira, sistemas monofásicos e trifásicos sem cruzeta e caminhamento otimizado. Pontos que seriam retomados trinta anos mais tarde pelo programa "Luz da Terra", que previa a mesma filosofia.

Hoje, poucas são as que mantêm os padrões de rede da época da implantação. Há uma tendência "modernizante", substituindo padrões simplificados por outros de maior capacidade. Em alguns casos, perfeitamente justificável mas, muitas vezes, sem estudos que indiquem essa necessidade. Em boa parte busca-se uma mimetização dos padrões da concessionária vizinha.

Quanto à manutenção e estado físico das redes de distribuição das cooperativas, os inspetores não encontraram problemas graves, seja na área rural ou urbana. Esse ponto foi considerado satisfatório e bom em várias cooperativas. Há medição em todos os consumidores, e não foram relatados problemas significativos nos níveis de tensão.

Muitas das cooperativas vêm procurado modernizar a gestão, investindo em sistemas computacionais de gerenciamento de rede. A troca de experiências é grande, principalmente através da Federação. 
Quase todas têm, como responsável técnico, um ou mais engenheiros em tempo integral. Os veículos e o pessoal técnico são bem equipados, em número suficiente para a prestação do serviço, com tendência até a um certo excesso.

Duas curiosidades: no município de São Paulo, a alguns quilômetros do centro, a Ceris atende um bairro de baixa renda, na borda da Represa Guarapiranga. Neste bairro, inclusive, a cooperativa foi pioneira na implantação de padrões simplificados para moradores de baixa renda, antes da Eletropaulo.

Em Ibiúna, a Cetril atende o sítio do ex-presidente Fernando Henrique Cardoso, bem como de vários ex-ministros e deputados. Nunca foram reportados problemas no atendimento desses consumidores "sensíveis". Na época do governo do ex-presidente, a Cetril dedicava cuidados especiais quando da sua presença, orientada pela segurança governamental.

$\mathrm{Na}$ área rural, o atendimento ao consumidor é bastante bom, em sua própria avaliação. Em comparação com o serviço da concessionária, há relatos de melhor atendimento. Há uma tendência de, nas cooperativas menores, o atendimento ser mais "personalizado", resultando numa percepção melhor pelo consumidor. Nas cooperativas maiores não é tão visível essa diferença.

A principal reclamação dos consumidores é em relação ao custo do serviço, principalmente nas cooperativas menores. Há casos em que os preços cobrados são quase o dobro da concessionária local, gerando insatisfação.

Os procedimentos comerciais do setor elétrico não são seguidos. Há uma cobrança generalizada de taxas de manutenção, e de consumo mínimo. A exigência de "jóia", seja na forma de cobrança mínima de "quotas-parte", "kVA", ou outra forma, produz situações, em algumas cooperativas, que impedem a ligação de novos consumidores, favorecendo a ligação clandestina. Em cooperativas que foram mais agressivas na busca de mercado, procurando ligar loteamentos, esse tipo de cobrança, comum em todas no início das atividades, não existe mais. 
A avaliação geral obtida por parte do consumidor foi boa, ressalvando-se a questão do custo e taxas cobrados.

Este é um ponto que preocupa, pela incapacidade de intervenção do órgão regulador. Como a cooperativa de eletrificação rural é um agente que não possui, formalmente, autorização para comercializar energia mas, na prática, o faz, o poder concedente e o órgão regulador não podem interferir nas relações entre a cooperativa e seus cooperados. Em alguns casos, se configuram situações de exploração comercial monopolística, em que o cooperado/consumidor está sujeito a procedimentos que são regulamentados justamente para que não ocorram abusos. Nessas situações, o órgão regulador é impotente para agir, como no caso das concessionárias, enquanto a cooperativa não é regularizada.

\subsection{Os principais conflitos}

O principal conflito, e que foi objeto de detalhe no processo de inspeção da cooperativas, é em relação à determinação da área de atuação da cooperativa.

Os conflitos na área de atuação têm origem histórica: a cooperativa, à medida que o seu mercado foi crescendo, expandiu os serviços a todos os tipos de consumidores. Isto é mais visível em regiões onde houve maior desenvolvimento no estado, como as regiões de Mogi Mirim, Porto Ferreira, São José do Rio Preto, entre outras. Nessas regiões surgiram loteamentos urbanos periféricos nascidos do desmembramento de fazendas, que passaram a ser atendidos pela cooperativa, já que esta tinha instalações mais próximas. Em muitos casos, isso trouxe um fortalecimento da cooperativa como empresa distribuidora de energia, com o atendimento de mercados mais atraentes.

A concessionária, observando esse fato e em busca de reservas de mercado, passou, em alguns casos, a estender redes que avançavam sobre um território já atendido pela cooperativa. À parte a razão jurídica de uma parte ou de outra, o fato é que surgiram muitos lugares onde há instalações físicas de dois agentes concomitantemente. Além do risco à segurança, causado por paralelismos e 
cruzamentos de rede, acaba sendo antieconômico, para toda a sociedade, a duplicação de investimentos em infra-estrutura para realizar o mesmo serviço. O serviço físico de distribuição de energia elétrica é, por sua natureza, um monopólio natural.

As figuras 7.2, 7.3 e 7.4 mostram alguns exemplos de conflitos dessa natureza:

Figura 7.2 - Conflitos: cruzamentos de rede em Mogi Mirim

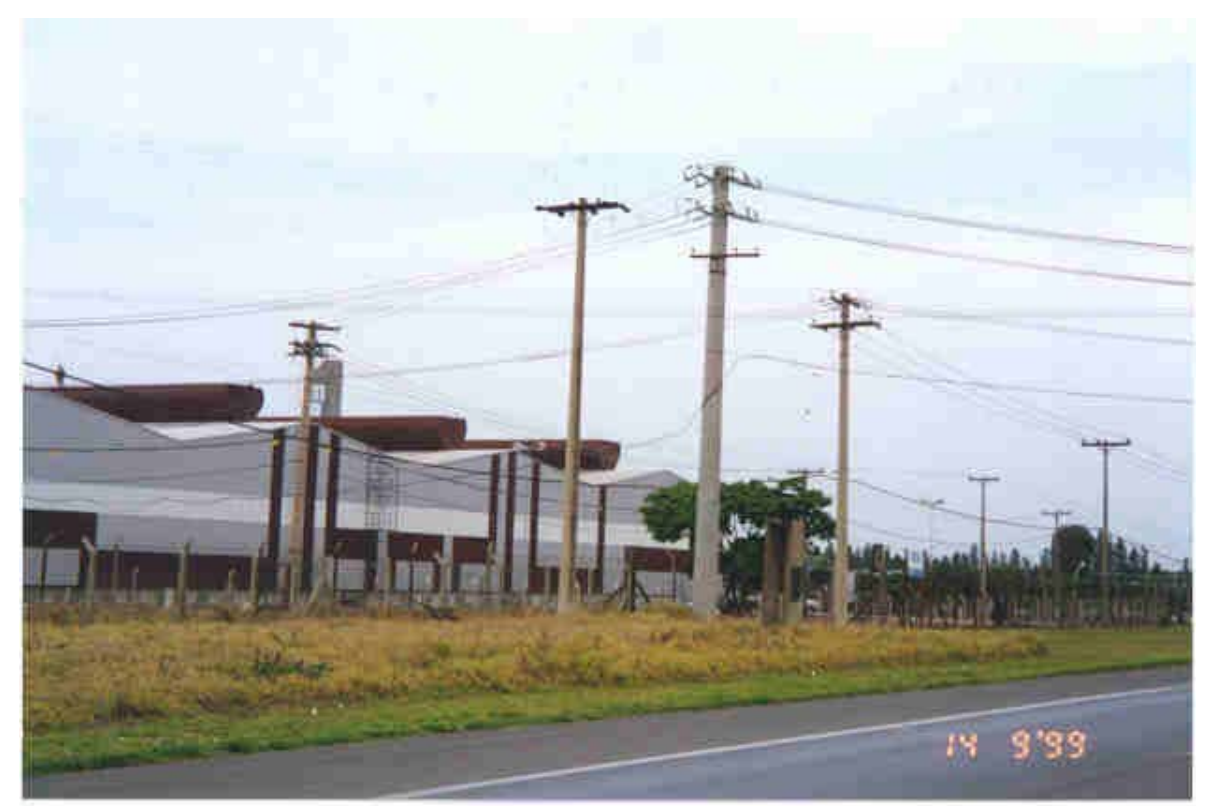

Cruzamento de redes entre a Elektro e Cemirim 
Figura 7.3 - Conflitos: cruzamentos de rede em São José do Rio Preto

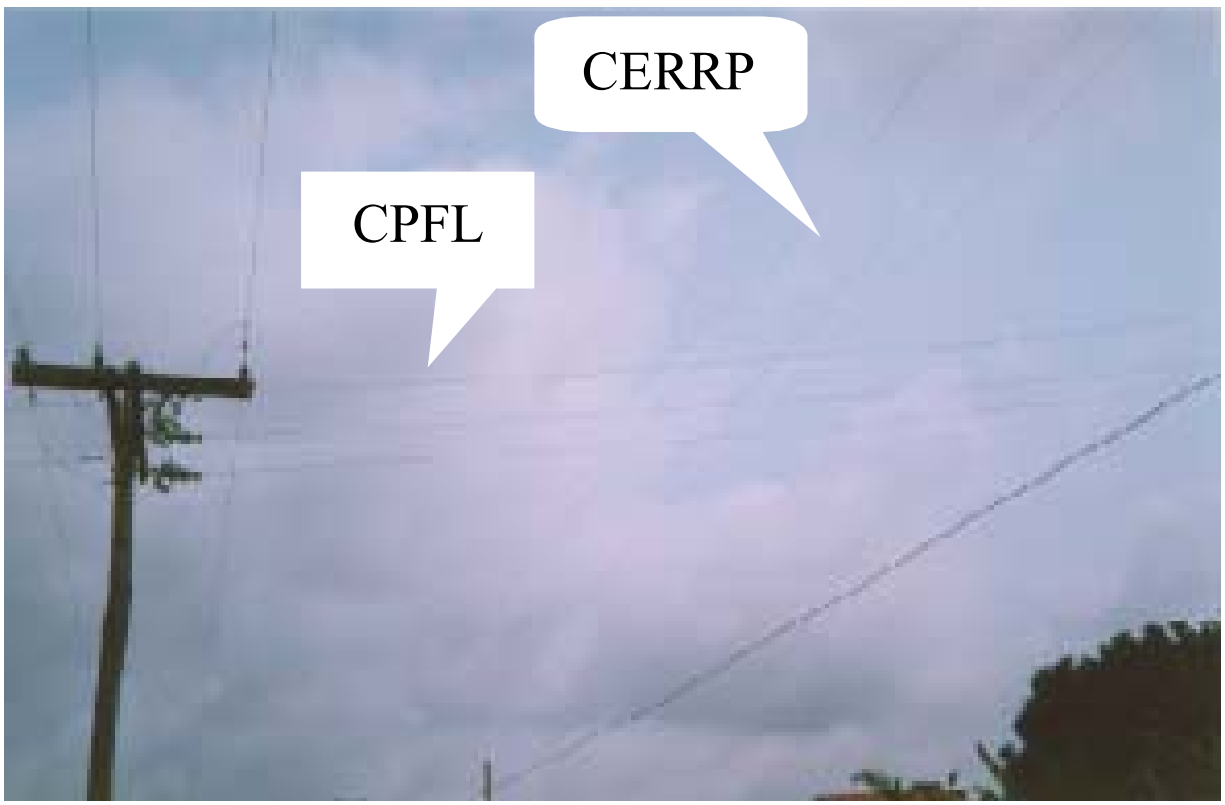

Cruzamento de Redes entre a CPFL e a Cerrp

Figura 7.4 - Conflitos: paralelismo de rede em Porto Ferreira

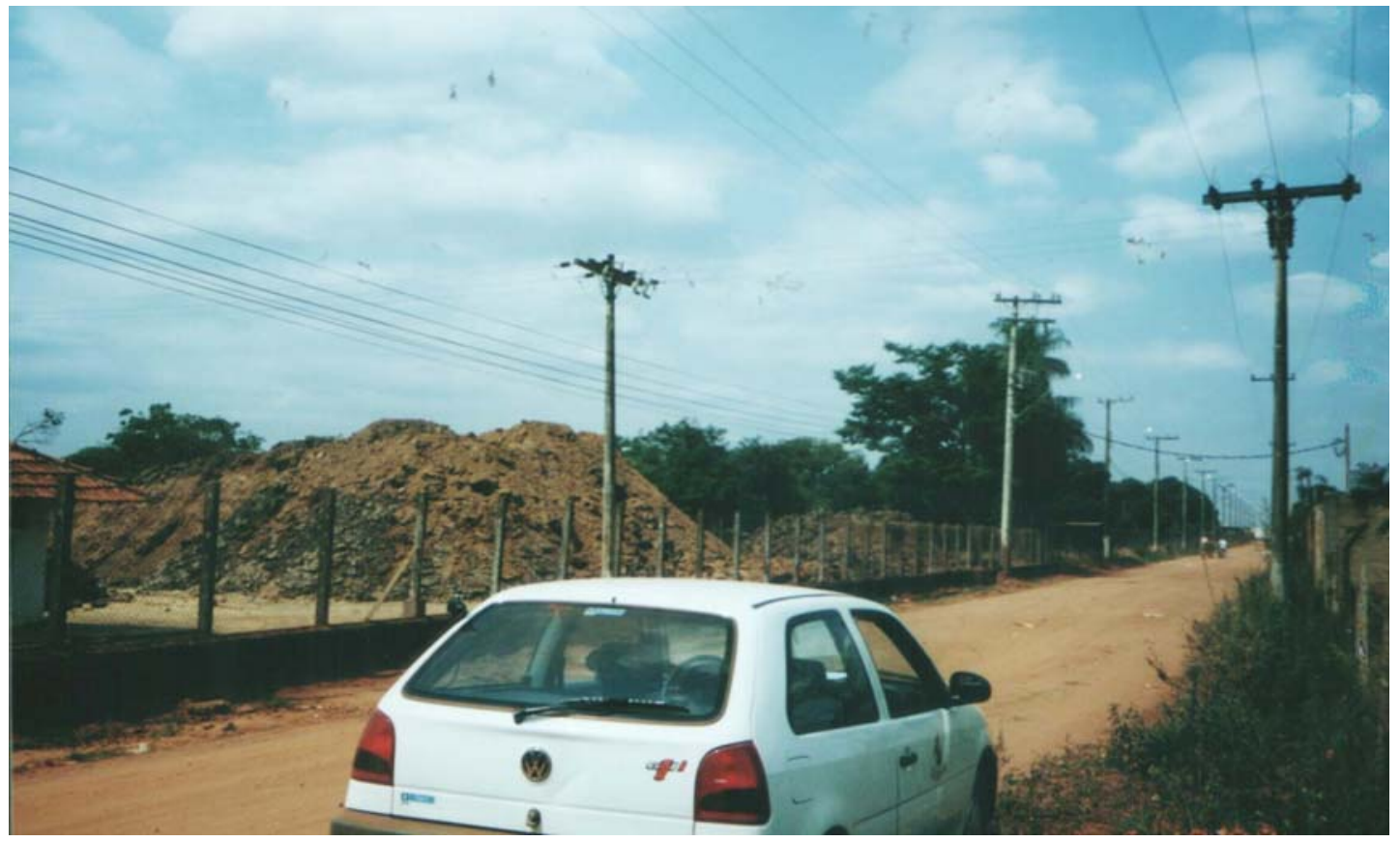

Linha paralela e cruzamento de rede. a rede da esquerda é da Elektro e a da direita da Cervam. A derivação atende uma indústria cerâmica. 
Exemplos como os mostrados são bastante comuns e existem em todas as cooperativas de São Paulo, em maior ou menor grau, trazendo grandes riscos para a operação do sistema e para os consumidores. Já foram relatados casos de acidentes, alguns deles fatais, envolvendo empregados de cooperativas e concessionárias, por conta de cruzamentos de rede. Em outros casos, houve disputa, com a construção de redes no mesmo local, entre os dois agentes.

Em Porto Ferreira, inclusive, ocorre uma curiosidade: a Cervam tem redes envolvendo praticamente todo o núcleo urbano do município. Eventuais expansões da área urbana estarão sempre mais próximas da rede da cooperativa, o que era motivo de grandes questionamentos da concessionária local, Elektro, e causa de conflitos freqüentes.

Os conflitos em relação à área eram conhecidos, mas não num grau tão detalhado. A pesquisa permitiu dimensionar o problema, preparando a agência para os procedimentos de regularização que viriam em seguida. 


\section{CAPÍTULO 8 - OS CONFLITOS REGULATÓRIOS}

\subsection{0 processo de regularização - 2000/2001}

Só após a Resolução 333/99 ser emitida, iniciou-se, na prática, o processo de regularização das cooperativas de eletrificação rural, embora já houvesse discussões e ações da CSPE no sentido de antecipar algumas etapas.

Apenas a partir daí ficaram claros para as concessionárias, o órgão regulador e as cooperativas as dificuldades e os problemas desse processo.

A Resolução 333/99 estabeleceu regras para o processo de regularização. Em até 90 dias, cada cooperativa deveria requerer a abertura de processo administrativo junto a Aneel (Art. 12), prazo este que foi prorrogado posteriormente por mais 30 dias. A Aneel recebeu requerimentos válidos de abertura de processo para 130 cooperativas no total, distribuídas da seguinte maneira, por estado:

Tabela 8.1 - Cooperativas por estado

\begin{tabular}{|l|c|c|c|}
\hline \multicolumn{1}{|c|}{ Estado } & $\begin{array}{c}\text { Número de } \\
\text { Cooperativas }\end{array}$ & $\begin{array}{c}\text { Número de } \\
\text { Municípios }\end{array}$ & $\begin{array}{c}\text { Número de } \\
\text { consumidores }\end{array}$ \\
\hline CEARÁ & 12 & 18 & 11.473 \\
\hline GOIÁS & 13 & 150 & 10.174 \\
\hline MATO GROSSO & 1 & 9 & 823 \\
\hline MATO GROSSO DO SUL & 4 & 32 & 4.533 \\
\hline MINAS GERAIS & 4 & 28 & Não Declarado \\
\hline PARÁ & 1 & Não Declarado & Não Declarado \\
\hline PARAÍBA & 7 & 85 & 6.511 \\
\hline PARANÁ & 7 & 39 & 8.167 \\
\hline PERNAMBUCO & 11 & 148 & 50.055 \\
\hline PIAUÍ & 1 & 38 & 2.653 \\
\hline RIO DE JANEIRO & 5 & 18 & 24.207 \\
\hline RIO GRANDE DO NORTE & 8 & 169 & 28.802 \\
\hline RIO GRANDE DO SUL & 15 & 387 & 179.639 \\
\hline RONDÔNIA & 1 & 3 & Não Declarado \\
\hline SANTA CATARINA & 21 & 120 & 114.331 \\
\hline SÃO PAULO & 17 & 145 & 38.269 \\
\hline SERGIPE & 1 & 1 & 3.126 \\
\hline TOTAL & $\mathbf{1 3 0}$ & $\mathbf{1 . 4 0 2}$ & $\mathbf{4 2 1 . 2 3 5}$ \\
\hline Fonte: Aneel. & & & \\
\hline
\end{tabular}


Os valores sobre o número de consumidores se referem ao ano de 1999 (o que explica a discrepância com os dados já mostrados das cooperativas de São Paulo) e, em alguns estados, não incluem todas as cooperativas, que não forneceram esse número. Uma estimativa para o ano de 2003 é de que existam cerca de 500.000 consumidores atendidos por cooperativas em todo o Brasil.

Os procedimentos para regularização são parte do processo administrativo e, no caso das cooperativas, podem ser resumidos nas seguintes etapas:

1. Abertura do processo administrativo na Aneel.

2. Instrução do processo administrativo, constituído de documentos, relatórios de diligências e relatórios de definição de áreas de atuação.

3. Conclusão do processo administrativo, com a elaboração de parecer técnico de enquadramento.

4. Emissão de documentos legais, como resoluções, deliberando sobre a regularização de cada cooperativa.

5. Assinatura de contrato de adesão (no caso de permissionárias).

A Aneel coordena os procedimentos de regularização e em São Paulo, repassou todos os trâmites relativos ao processo administrativo à CSPE. Os recursos humanos eram escassos. A equipe que tratava na CSPE desse assunto (para regularização de 17 cooperativas) era de mesmo número que a equipe da Aneel, para o restante do Brasil (2 pessoas).

A pesquisa efetuada durante o ano de 1999 serviu para traçar um retrato inicial das condições para regularização. Em geral, as cooperativas de São Paulo não possuíam dificuldades na obtenção e levantamento de dados e fornecimento de documentos.

Aqui se vê um ponto em que a atuação da CSPE foi bastante positiva. Ao realizar as inspeções, foi montada uma planilha de consolidação dos principais dados técnicos da cooperativa. No Anexo 1 da Resolução 333/99, a Aneel solicitava às 
cooperativas informações que se basearam nessa planilha, facilitando assim o trabalho das cooperativas de São Paulo, que já possuíam essas informações.

O grande trabalho, então, era a definição das áreas de atuação. Este sempre foi o ponto crítico, por confrontar diretamente os interesses opostos das cooperativas e concessionárias. A definição das áreas de atuação implica a definição do mercado, atual e futuro e, em conseqüência, a rentabilidade dos ativos das duas partes.

Para resolver o problema da definição da área, a Resolução 333/99 determina, nos artigos 16 a 22, procedimentos às partes e ao órgão regulador. O que se quer é a busca de uma solução negociada pelas partes, com a mediação da CSPE/Aneel. O Art. 18 define esses procedimentos:

"Art. 18. Para fins de atribuição de responsabilidade de atendimento nos locais onde coexistirem instalações de energia elétrica pertencentes à cooperativa e à concessionária, a primeira deverá apresentar, no prazo de até noventa dias, a contar da abertura do respectivo processo administrativo, proposta para demarcação dos locais de sua atuação.

$\S 1^{\circ}$ No caso da proposta de demarcação ser apresentada de comum acordo entre cooperativa e concessionária, e atendidas as disposições da presente Resolução, a mesma será homologada pela Aneel.

$\S 2^{\circ}$ No caso da proposta de demarcação apresentada não ter sido objeto de acordo prévio entre as partes, a Aneel poderá, sucessiva ou alternativamente:

I - estabelecer prazo para que as partes envolvidas procedam negociações visando definir os respectivos perímetros de atuação;

II - solicitar às partes envolvidas a apresentação de relatório explicitando os pontos de convergência e de divergência, bem como as alternativas de solução encaminhadas; elou

III - estabelecer os procedimentos e as diligências julgadas necessárias para a conclusão da demarcação do local de atuação e definição do agente responsável pelo atendimento."

Como se vê, são linhas gerais que, no caso de ser necessária uma mediação, deixa para o órgão regulador a definição de critérios mais objetivos para a demarcação da área. Isso é proposital, para preservar um certo poder discricionário da Aneel. 
A CSPE foi seguindo os procedimentos do Art. 18. O norte sempre foi o de incentivar a negociação prévia entre as partes, dentro do princípio que um acordo efetuado entre os agentes é preferível a uma arbitragem de um terceiro. A proposta de demarcação apresentada de comum acordo seria homologada desde que não houvesse prejuízo aos consumidores.

Num primeiro momento, a CSPE identificou as fronteiras que deveriam ser objeto de negociação. A partir de uma análise geográfica, foram identificadas 30 intersecções entre as cooperativas e as concessionárias, pois há concessionárias que não possuem atuação de cooperativas em suas áreas, assim como há atuação de uma cooperativa em duas ou mais áreas de diferentes concessionárias. Estas intersecções estão relacionadas na tabela 8.2 abaixo:

Tabela 8.2 - Intersecções entre cooperativas e concessionárias em São Paulo.

\begin{tabular}{|c|c|}
\hline Cooperativa & Concessionárias em Contato \\
\hline CEDRAP & Elektro e Bandeirante \\
\hline CEDRI & Elektro \\
\hline CEMIRIM & Elektro, CPFL e Jaguari \\
\hline CERFRA & CPFL \\
\hline CERIM & Elektro e Bandeirante ${ }^{16}$ \\
\hline CERIPA & Elektro, Santa Cruz e CPFL \\
\hline CERIS & Eletropaulo \\
\hline CERMC & Bandeirante \\
\hline CERMESO & Santa Cruz \\
\hline CERNHE & CNEE \\
\hline CEROC & EEVP e Caiuá \\
\hline CERPAL & CPFL e EEVP \\
\hline CERPRO & CPFL \\
\hline CERRP & CPFL e CNEE \\
\hline CERT & EEVP, Caiuá e CPFL \\
\hline CERVAM & Elektro e CPFL \\
\hline CETRIL & Elektro e Bandeirante \\
\hline Fonte: CSPE. & \\
\hline
\end{tabular}

Em seguida, com o objetivo de consolidar as informações a respeito das áreas de atuação das cooperativas, foi solicitada a elas e às concessionárias uma proposta inicial de demarcação de área de atuação. Em paralelo, foi incentivada a negociação

\footnotetext{
${ }^{16}$ Em 2001, a Bandeirante sofreu uma cisão, passando a metade Oeste ao controle da CPFL. Surgiu uma nova empresa, denominada Companhia Piratininga de Força e Luz - CPFL - Piratininga. À época das negociações, a Bandeirante ainda não havia feito a cisão.
} 
entre as partes, visando principalmente a definição daquelas intersecções onde não houvesse coexistência de redes.

Através do acompanhamento das ações, no fim do prazo estabelecido verificou-se que o processo de negociação não havia avançado, constatando-se a necessidade de realização de reuniões de mediação com a intermediação da CSPE.

As primeiras cooperativas convocadas foram aquelas em que havia maior dificuldade de definição e que se esperava o enquadramento como permissionárias. Foram realizadas 30 reuniões no primeiro semestre de 2000, inclusive, em uma delas, com a participação direta da Aneel, iniciando um processo formal de negociação das áreas de atuação.

Nestas reuniões, o objetivo principal era estabelecer metas de trabalho conjunto entre as concessionárias e cooperativas visando a definição das áreas o mais breve possível. Entre as dificuldades detectadas, estava a carência de cadastros atualizados que facilitassem o conhecimento claro e seguro das redes e dos consumidores, tanto das concessionárias como das cooperativas.

De início, viu-se que havia espaço para entendimento entre os agentes mas, no decorrer das conversas, as suas posições foram mudando, principalmente das concessionárias.

O resultado das reuniões com a mediação da CSPE variou em cada caso, de acordo com o interesse próprio de cada concessionária. No caso da Santa Cruz, Bandeirante e Jaguari, houve um rápido entendimento, apesar de envolver fronteiras onde havia grandes conflitos de redes, como a Cetril/Bandeirante e Ceripa/Santa Cruz. O acordo obtido para essas concessionárias envolveram, em muitos casos, a troca de ativos. Em São José dos Campos, a Bandeirante comprou os ativos da Cedrap a preços considerados vantajosos para a cooperativa, o que gerou expectativas da utilização da mesma base em outras cooperativas.

No caso das empresas do Grupo Rede (Caiuá e EEVP) também houve um entendimento, facilitado porque as cooperativas em questão (Cert, Ceroc e Cerpal) 
inicialmente reuniam condições para regularização como autorizadas. Numa autorizada, a área de atuação é apenas uma referência para futuras expansões, já que a concessionária local permanece com os deveres da concessão naquelas áreas.

As três concessionárias e, em certa medida, o Grupo Rede, perceberam que o problema da definição da área era relativo a uma parcela ínfima do seu mercado, e decidiram resolver a questão através de acordos, sem discussões desgastantes com o órgão regulador e as cooperativas.

Já as outras concessionárias tiveram uma atitude bastante diferente. A Elektro e a CPFL são as empresas com maior número de fronteiras com cooperativas e, em muitos casos, há um histórico de conflitos bastante recente. Embora no início houvesse disposição da empresas em negociar áreas, até com troca de ativos, no decorrer do processo forem sendo adotadas atitudes mais intransigentes. A CPFL chegou a propor até mesmos a compra dos ativos de algumas cooperativas, o que acabou soando ofensivo.

O recuo da CPFL e Elektro na negociação muito provavelmente refletia um questionamento da Abradee (Associação Brasileira das Distribuidoras de Energia Elétrica), que representa as distribuidoras em questões que envolvam interesses comuns junto à Aneel, em relação à Resolução 333/99.

Alguns pontos dessa resolução já eram objeto, desde a audiência pública, de questionamento pelas distribuidoras. Entre eles, o fato de que a resolução não tratava somente da questão das cooperativas de eletrificação rural, mas também definia, de modo geral, o instrumento da autorização e permissão. No entender das distribuidoras, isto abria brechas para que fosse possível a outorga de autorizações para clientes que estivessem inclusive na área urbana, que extrapolaria o objetivo inicial de regularização das cooperativas e iria contra a legislação estabelecida.

Assim, por não concordar com estes pontos, bem como com a definição da área da cooperativa permissionária como aquela existente de fato, a Abradee entrou, no início de 2001, com uma ação na justiça federal solicitando a anulação da Resolução 333/99. De imediato, obteve uma liminar que sustava, até o julgamento do 
mérito da ação, os atos baseados nela. Isso significava que a Aneel não poderia emitir resoluções de enquadramento nem, em conseqüência, assinar contratos de adesão para as permissionárias, embora pudesse dar prosseguimento à instrução dos processos administrativos.

Apesar da ação judicial datar do início de 2001, já estava em discussão pela Abradee desde o $2^{\circ}$ semestre de 2000. Deste modo, houve um recuo, pelas concessionárias de São Paulo, dos entendimentos em relação à definição de áreas.

No final de 2000, a situação era a seguinte, em relação aos acordos: 
Figura 8.1 - Quadro demonstrativo da negociação de áreas entre cooperativa e concessionárias em São Paulo - 2000

\begin{tabular}{|c|c|c|c|c|c|c|c|c|c|}
\hline Coop/Cons & Elektro & CPFL & Bandeirante & Eletropaulo & Sta. Cruz & EEVP & CNEE & Caiuá & Jaguari \\
\hline \multicolumn{10}{|l|}{ CETRIL } \\
\hline \multicolumn{10}{|l|}{ CEMIRIM } \\
\hline \multicolumn{10}{|l|}{ CERVAM } \\
\hline \multicolumn{10}{|l|}{ CERFRA } \\
\hline \multicolumn{10}{|l|}{ CERRP } \\
\hline \multicolumn{10}{|l|}{ CERNHE } \\
\hline \multicolumn{10}{|l|}{ CEDRAP } \\
\hline \multicolumn{10}{|l|}{ CEDRI } \\
\hline \multicolumn{10}{|l|}{ CERIS } \\
\hline \multicolumn{10}{|l|}{ CERPRO } \\
\hline \multicolumn{10}{|l|}{ CERIM } \\
\hline \multicolumn{10}{|l|}{ CERIPA } \\
\hline \multicolumn{10}{|l|}{ CERMC } \\
\hline \multicolumn{10}{|l|}{ CERMESO } \\
\hline \multicolumn{10}{|l|}{ CEROC } \\
\hline \multicolumn{10}{|l|}{ CERPAL } \\
\hline \multicolumn{10}{|l|}{ CERT } \\
\hline \multirow{2}{*}{\multicolumn{10}{|c|}{ Legenda: }} \\
\hline & & & & & & & & & \\
\hline & \multicolumn{8}{|c|}{ Acordo firmado entre cooperativa e concessionária } & \\
\hline & \multicolumn{9}{|c|}{ Negociação suspensa com necessidade de mediação e demarcação } \\
\hline Fonte: $C S P L$ & & & & & & & & & \\
\hline
\end{tabular}

O resultado foi que, até o fim de 2000, haviam sido estabelecidos "Termos de Acordo" para apenas 7 cooperativas, das 17 existentes, representando 16 das 30 fronteiras. Ressalta-se que as que restaram são as que possuem maiores conflitos.

A ação judicial proposta acabou deixando em suspenso o processo de definição de áreas. Houve algumas tentativas, durante o final de 2000 e o primeiro semestre de 2001, de mediação da CSPE, visando ainda o estabelecimento de algum acordo, sem obter sucesso. Além disso, o ano de 2001 foi tomado pela questão do racionamento, que drenou boa parte das atenções da CSPE, inclusive na orientação às cooperativas quanto aos procedimentos a adotar.

Como não havia impedimento ao andamento do processo administrativo, a CSPE, seguindo os procedimentos da Resolução 333/99 iniciou, no segundo semestre de 2001, a arbitragem das áreas de atuação nas cooperativas onde não havia 
sido realizado acordo com a concessionária, através da demarcação de poligonais envolventes às regiões onde cada cooperativa atua.

\subsection{Os argumentos da Abradee}

A Abradee, no início de 2001, entrou com ação junto à Justiça Federal pedindo a anulação da Resolução 333/99. É interessante notar que os advogados autores da ação são Souto e Loureiro, advogados do escritório Veirano \& Associados, já utilizados como referência bibliográfica deste trabalho, e que criticam ferinamente a atuação das cooperativas de eletrificação rural.

A argumentação básica da ação era contra os instrumentos instituídos pela resolução, notadamente contra o instrumento da autorização para o setor de distribuição de energia elétrica.

A Resolução 333/99 instituiu a figura do autorizado de maneira ampla, permitindo que um consumidor, pessoa física ou jurídica, individualmente ou associada, operasse instalações de energia elétrica para uso privativo, isto é, sem caracterizar serviço público. Estas instalações poderiam ser disponibilizadas para outros usuários ou usada pela concessionária, para atender consumidores do serviço público.

Como não há distinção clara no texto, a autorização poderia ser efetuada em área urbana ou rural. Daí o temor das distribuidoras de que, dentro de cada área de concessão, fossem autorizadas pela Aneel várias instalações de uso privativo, retirando assim o monopólio da distribuidora sobre o mercado. Em tese, o caráter de unicidade das redes ficaria garantido, pois a concessionária poderia ter livre acesso a essas instalações, apesar de não ser proprietária e responsável.

A cooperativa que não viesse a se tornar permissionária seria enquadrada como autorizada, com as mesmas características do consumidor autorizado.

A Abradee argumenta contra essa figura alegando que uma resolução não poderia definir os casos onde se aplica a autorização, e sim somente uma lei: 
"Vale dizer: a tipificação dos atos de delegação do serviço de energia elétrica, bem como seus usos está descrita em lei; é a lei que disciplina os casos em que se aplicam os institutos da concessão, permissão ou autorização.

Pois bem: em nenhum momento, a lei 9.074/95, ou qualquer outra lei do setor, previu a figura do 'auto-distribuidor' (i.e. consumidor que detém e opera instalações de distribuição para seu 'uso privativo' (...)).

Pois é isto o que faz a Aneel: cria um uso todo particular de autorização para consumidores deterem e operarem linhas de energia elétrica e, o que é pior, em alguns casos, configurando, de fato, distribuição de energia elétrica a terceiros, sem base legal alguma.

\section{(...)}

ao criar o 'auto-distribuidor', a Aneel invade campo reservado à lei, que regulou, sem margem de criatividade para a administração, os usos da autorização, consagrando, nesta seara (dos 'usos privativos'), apenas a autorização para a figura do auto-produtor"(ABRADEE, 2001, pg.8)

No caso da permissão, ou das cooperativas permissionárias, os autores apontam a irregularidade no Art. 23, argumentando contra a regularização:

"Antes do advento da Constituição Federal, em particular o seu artigo 175, e das novas leis do setor, o poder público excogitou uma forma de incentivar a eletrificação rural, porquanto, em razão dos baixos índices de eletrificação rural, da configuração legislativa pretérita, não havia a serem exigidas das concessionárias metas cogentes de universalização dos serviços. Este não é mais o caso. Por tudo isso e para esse especifico fim, foi criado, por força do Dec. 62.655/68 um serviço não público de distribuição em áreas rurais.

Tal serviço, de natureza complementar e provisória ao serviço público, operava a partir da formação de uma pessoa jurídica - normalmente cooperativa - que, autorizada a construir e operar redes de sua propriedade no meio rural, conectava-se em um ponto qualquer, às redes da concessionária, dali recebendo a energia que repassava a seus consumidores, necessariamente associados localizados em zona rural. Essas cooperativas não realizavam serviço público e eram consideradas consumidores do concessionário de distribuição local.

Com o tempo e a inércia do Poder Concedente, permitiu-se o avanço indiscriminado dessas cooperativas, em desrespeito ao ato autorizativo que possuíam, pois que passaram a atender não apenas associados localizados no campo, mas qualquer consumidor, inclusive em centros urbanos. Isto tudo dentro das áreas das concessionárias. Situações há em que atuam concessionárias e cooperativas na mesma cidade, com um inadmissivel imbróglio de redes. 
A situação de irregularidade era flagrante, a tal ponto que o legislador, através do Art. 23 (na interpretação que dele faz a Aneel) resolveu, ignorando a solução que se impunha - cassação da autorização, com a incorporação do serviço não público naquele público, mediante indenização dos ativos das cooperativas -, 'premiar' tais agentes com o título de permissionários de serviço público. Antes, simples privados que desrespeitavam os limites de suas autorizações; agora, futuros prestadores de serviço público!"'(ABRADEE, 2001, pg. 9)

Nesse ponto, os autores fazem uma esperteza jurídica. Como o objeto da ação não é o Art. 23 da Lei 9.074/95, mas sim a Resolução 333/99, o argumento utilizado é oblíquo, alegando que, para aplicação do artigo, deveria haver licitação, ou deveria ter sido feita a regularização à época da prorrogação das concessões ${ }^{17}$, ou ainda, que a figura da cooperativa não é compatível com a do permissionário.

A não-contestação direta do Art. 23, como poderia se esperar, não é realizada, pois poderia trazer à tona uma questão básica: no processo de reagrupamento e prorrogação das concessões das distribuidoras também não houve licitação para as áreas existentes.

A ação da Abradee teve como resultado imediato a expedição de uma liminar sustando o processo de regularização em seus atos finais, isto é, a Aneel poderia prosseguir com os trâmites administrativos, mas não expedir os atos finais.

A Aneel contra-argumentou pedindo a cassação da liminar, em junho de 2001, que não foi concedida.

As cooperativas, nesse meio-tempo, chegaram a ameaçar a Abradee com a entrada de ações contra o processo de prorrogação das concessões. Em ofício da Fecoerpa à Abradee, de setembro de 2001, é dada a seguinte argumentação:

“A lei 9.074/95, pode-se afirmar, foi uma lei generosa para com os agentes do setor elétrico de então.

De fato, as empresas concessionárias distribuidoras, por exemplo, foram agraciadas com a possibilidade de 'agrupar' os vários contratos de concessão dos quais eram titulares e o 'reagrupamento' ganhou uma 'prorrogação' de 20 anos, ou mais.

\footnotetext{
${ }^{17} \mathrm{O}$ que não foi feito, como visto, mas postergado com uma cláusula nos contratos de concessão.
} 
Face o Art. 175 da Constituição Federal de 1988 essa graça estaria a merecer severos reparos, e face a Constituição como um todo, a situação é pior: não há praticamente nenhum Princípio Constitucional que não tenha sido ferido por aquela norma.

$\mathrm{Na}$ realidade, todos sabemos disso, não ocorreu no caso 'prorrogação' alguma, mas tratou-se de criar novos contratos de concessão e distribuição sem que, para isso, fossem precedidos das licitações de que fala o Art. 175, $\mathrm{CF} / 88$.

A Abradee entendeu, da mesma forma, que a transformação do regime jurídico de atuação das cooperativas do privado para o público, onde elas operariam com o título de permissionárias de serviços públicos, padeceria do mesmo vício e está buscando anular a Resolução 333/99 da Aneel, que disciplina o processo administrativo da transformação mencionado, através de ação judicial.

\section{(...)}

Sabemos todos que o questionamento à constitucionalidade ou inconstitucionalidade das normas legais pode ser feito diretamente ao STF, ou difusamente ante cada caso concreto.

Dessa forma cada cooperativa no país, junto ao seu juiz local, poderá argüir a nulidade do 'reagrupamento' e 'prorrogacao' do contrato do concessionário local.

Lembre-se que existia um número muito grande de contratos de concessão, objeto do 'reagrupamento', que abrangia áreas pequenas, envolvendo um ou poucos municípios, onde estão instaladas as cooperativas e, em não pouco desses casos, é a cooperativa quem detém a maioria dos ativos de distribuição.

Cada contrato desse, que tinham prazos de vencimentos distintos, ao seu final, ao invés de 'reagrupado' e 'prorrogado', deveria ter sido licitado. Não havendo licitação, frustraram-se os interesses das cooperativas de serem proponentes em certame licitatório e dai decorrem seus interesses processuais em, eventualmente, valerem-se também de ações judiciais anulatórias àqueles contratos.

Esta Federação ao avaliar o que pode ocorrer ante a hipótese de todas as cooperativas do país buscarem defesa junto ao Poder Judiciário não pode deixar de concluir que é grande a chance de um número significativo de ações, senão todas, serem deferidas a favor dos interesses cooperativistas."

Em clara atitude de confronto, a Fecoerpa conclui dizendo

"Não obstante, não se pode deixar de registrar, as cooperativas estão sendo atacadas e não terão outra opção senão defenderem-se. 
E nós o faremos, se necessário for."

\subsection{A resolução 012/02}

Com a ação judicial proposta pela Abradee havia se criado um impasse: apesar da Aneel e da CSPE estarem prosseguindo com o processo, analisando a documentação e propondo alternativas para a negociação das áreas, o ato final não podia ser expedido e as concessionárias se negavam a continuar com a negociação das áreas. O racionamento de 2001 contribuiu ainda para que as atenções fossem um pouco desviadas do assunto, já que houve, inicialmente, um grande questionamento do papel da Aneel.

Uma das conseqüências do racionamento foi o início de um processo de revisão do modelo do setor. Algumas questões, já há algum tempo pendentes, foram objeto de maior atenção dentro das esferas governamentais. No bojo destas ações foi empreendida então, pela Aneel, um processo de mediação com a Abradee e as associações das cooperativas, visando detectar os pontos que atravancavam o processo de regularização e proceder à revisão da Resolução 333/99.

Num processo de mediação, busca-se o diálogo e o entendimento das partes de modo que, através da cessão de posições dos dois lados, possa haver acordo sobre alguns pontos básicos. Nesse caso, em particular, a Aneel também era parte interessada, pois era responsável pela expedição dos atos legais.

Este processo de mediação foi realizado no segundo semestre de 2001, com a abertura às sugestões dos agentes para a modificação da Resolução 333/99. Foi aberta, então, a possibilidade de, com a experiência adquirida, rever alguns pontos obscuros e retomar os procedimentos para regularização.

A Abradee, em suas sugestões iniciais, queria que fosse eliminada da nova resolução a menção às autorizações e permissões em geral, fazendo com que se tratasse somente do processo de regularização. Outras sugestões visavam restringir bastante a atuação das cooperativas de eletrificação rural, e abriam a possibilidade da concessionária adquirir, de forma impositiva, as cooperativas. 
Na primeira minuta da Aneel, a sugestão da nova resolução só tratar de cooperativas foi aceita, mas mantiveram-se as principais disposições da Resolução 333/99 em relação às cooperativas permissionárias.

Após a divulgação dessa minuta, foram ouvidas sugestões da Abradee, da Infracoop, da Conbrac, da CSPE e da Agergs, e foram elaboradas outras minutas, até que, em janeiro de 2002, foi realizada na Aneel uma reunião, com a presença dos agentes e do diretor-geral da agência, para acertar os pontos finais da nova resolução.

Esta nova resolução foi publicada em 10 de janeiro de 2002, sob o número 012/02. As principais modificações em relação à Resolução 333/99 foram:

- A Resolução 012/02 trata somente do processo de regularização de cooperativas de eletrificação rural, remetendo para outra ocasião a questão da regulamentação dos instrumentos da permissão e autorização de modo geral.

- Para as cooperativas permissionárias: abertura de novos prazos para envio de documentos; manutenção dos procedimentos de negociação e definição de áreas de atuação; detalhamento de alguns pontos em que havia dúvidas de interpretação; previsão de novo regulamento estabelecendo as condições de compra e venda de energia.

- Para as cooperativas autorizadas: restrição na atuação (a autorizada só pode atender consumidores rurais e no caso de industriais, somente até $112,5 \mathrm{kVA}$ ) e enquadramento; impossibilidade de atendimento às áreas urbanas; expansões condicionadas à aprovação da concessionária ou da Aneel.

As mudanças foram extremamente positivas. No status anterior, o uso do instrumento de autorização indistintamente poderia criar grandes confusões em uma área em que o monopólio natural é claro, que é o "serviço de fio" no transporte e distribuição de energia. Poder-se-iam criar situações em que, numa determinada rede, alguns trechos fossem operados e mantidos por particulares, enquanto outros trechos seriam de responsabilidade da concessionária. 
$\mathrm{Na}$ atual configuração, inexiste a figura do consumidor autorizado e, no caso das cooperativas autorizadas, o seu raio de ação fica restrito ao que era originalmente, ou seja, os termos do Decreto 62.655/68. Eventuais expansões que extrapolem os limites ditados por aquele decreto só com a concordância da concessionária local, que continua com a responsabilidade por aquela área de concessão. A principal razão para a limitação clara da autorizada é evitar que no futuro elas venham a atender público indistinto e tenha-se a repetição dos problemas encontrados hoje.

Com a publicação da Resolução 012/02 e revogação da Resolução 333/99, a Abradee retirou a ação judicial e pôde-se então retomar o andamento do processo de regularização.

\subsection{As demarcações de áreas em São Paulo}

Voltando à cena de São Paulo, a publicação da Resolução 012/02 resolveu o impasse em relação à validade do processo de regularização, e das visões sobre os conceitos de permissionária e autorizada. Contudo, os impasses do processo de regularização continuaram, sobretudo no ponto crítico de definição de áreas de atuação.

A CSPE já havia iniciado a arbitragem das áreas das cooperativas onde não havia acordo, após todas as tentativas de negociação entre os agentes. Mesmo assim, deu um prazo para que houvesse novos entendimentos, o que não ocorreu. Continuou-se, assim o processo de demarcação.

A arbitragem das áreas de atuação, através do traçado de poligonais, exigiu a contratação de uma equipe de campo, que ia pessoalmente aos extremos da rede de cada cooperativa, obtendo as coordenadas geográficas dos pontos de fronteira. Onde havia a coexistência das redes, a equipe decidia, na presença de representantes da cooperativa e concessionária, qual o agente responsável pelo atendimento. É um trabalho árduo que, em algumas cooperativas, demandou mais de seis semanas ininterruptas. 
Para a realização dos trabalhos foi adotada a seguinte metodologia:

- Estabelecimento de critérios, de acordo com a legislação vigente.

- Análise cadastral das plantas eletrogeográficas das cooperativas e das concessionárias de distribuição de energia elétrica envolvidas.

- Análise das convergências e das divergências resultantes das negociações prévias entre as partes.

- Definição de roteiro a ser seguido para o levantamento em campo.

- Levantamento em campo:

- Visita a todos os pontos considerados significativos para a definição da área de atuação das Cooperativas, inclusive os cruzamentos de redes de distribuição.

- Coleta de informações necessárias para subsidiar a realização do estudo.

- Obtenção das coordenadas UTM (Universal Transversa de Mercator) através de aparelho GPS (Global Positioning System).

- Obtenção de fotos panorâmicas dos locais visitados.

- Triagem das informações obtidas no levantamento de campo

- Estudo de demarcação das áreas de atuação

Como resultado da aplicação da metodologia, para cada cooperativa foi emitido um relatório contendo por área demarcada e por Município, as coordenadas dos locais selecionados (pontos), descrição dos mesmos e fotos digitalizadas. Também foram elaborados mapas, de demarcação das áreas de atuação das Cooperativas utilizando software AutoCAD.

JUCÁ et al. (2003) reportam alguns dados sobre os trabalhos realizados.

- O levantamento em campo levou 13 dias úteis em média por cooperativa. 
- A elaboração do relatório e mapas em AutoCAD levou 12 dias úteis em média por cooperativa, totalizando um tempo médio total de 25 dias úteis por cooperativa, trabalhando-se em média 10 horas por dia, numa equipe de duas pessoas.

- Eram visitados 22 pontos em média por dia, percorrendo-se cerca de $145 \mathrm{~km}$.

Os pontos de fronteira eram determinados segundo os critérios mostrados a seguir, com fotos ilustrando sua aplicação:

Figura 8.2 - Limites naturais: matas, plantações de eucaliptos e áreas de preservação.
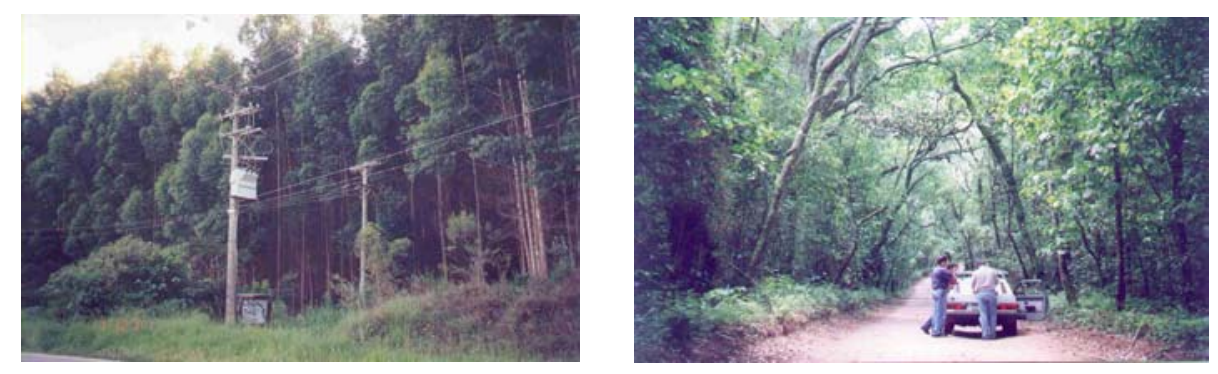

Figura 8.3 - Limites naturais: rios, córregos e ribeirões.
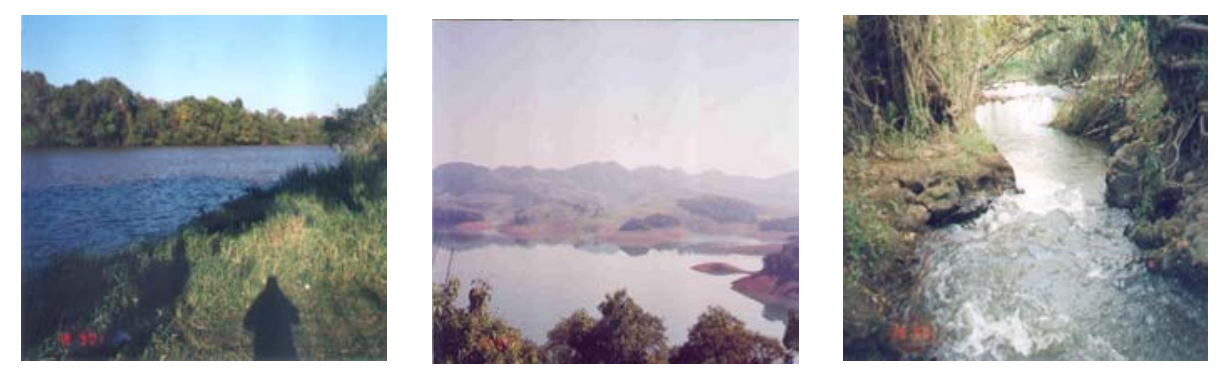
Figura 8.4 - Pontes e estradas rurais.
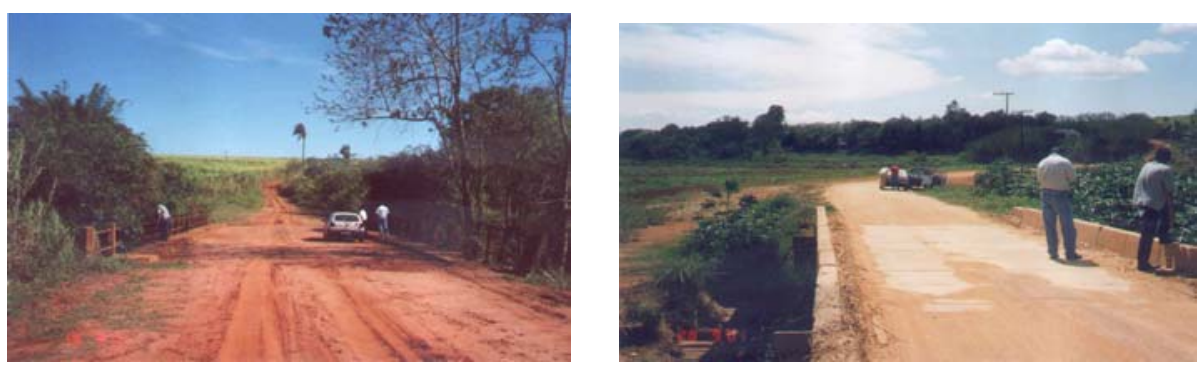

Figura 8.5 - Rodovias
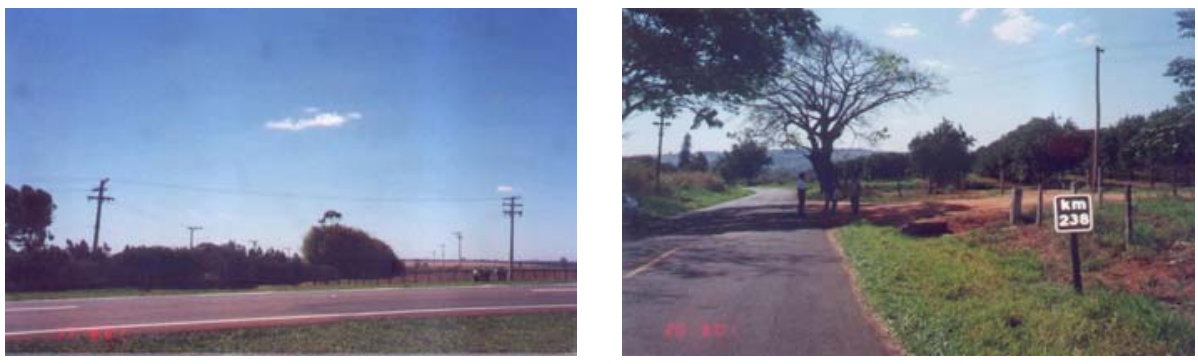

Figura 8.6 - Estradas de ferro

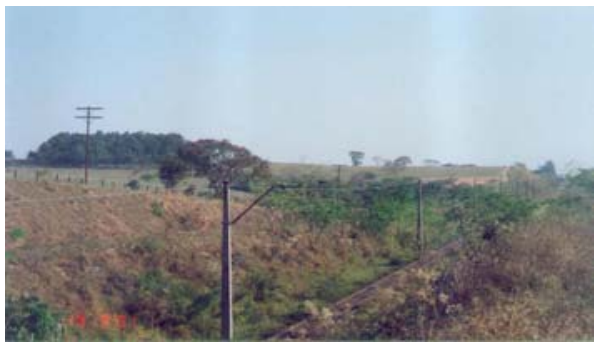

Figura 8.7 - Linhas de transmissão
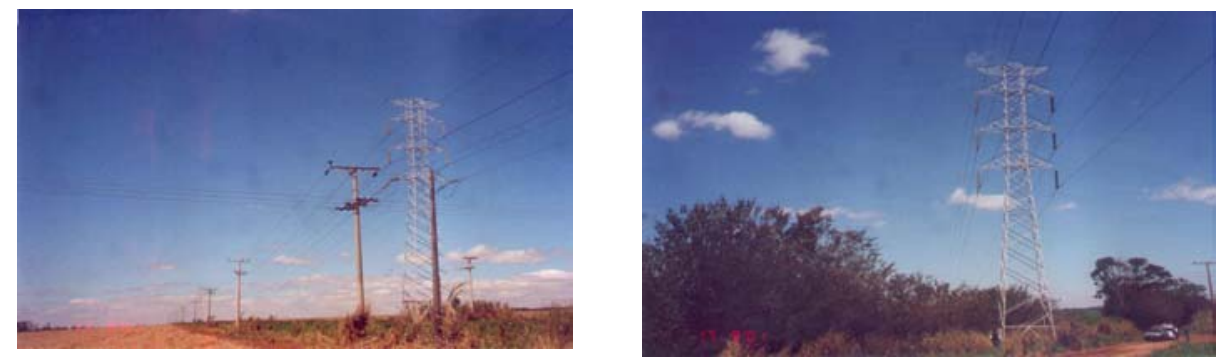
Figura 8.8 - Pontos extremos da rede de distribuição
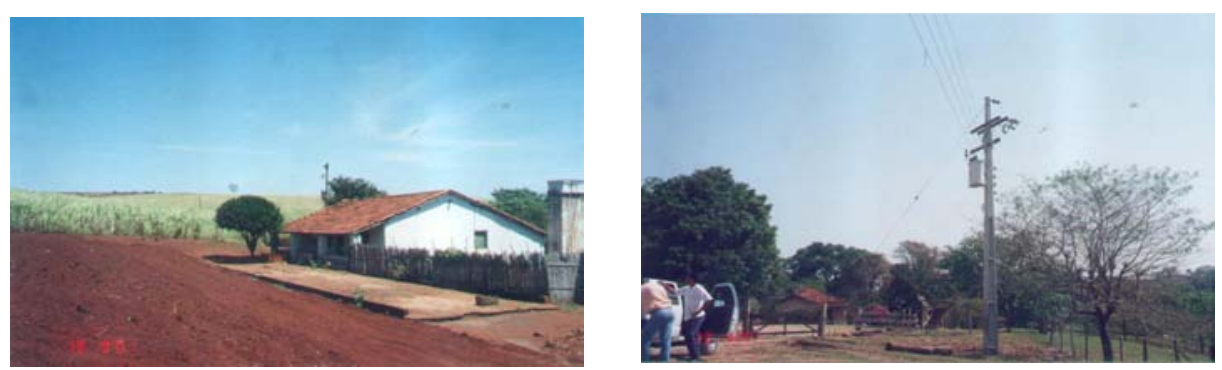

Figura 8.9 - Divisas de loteamentos
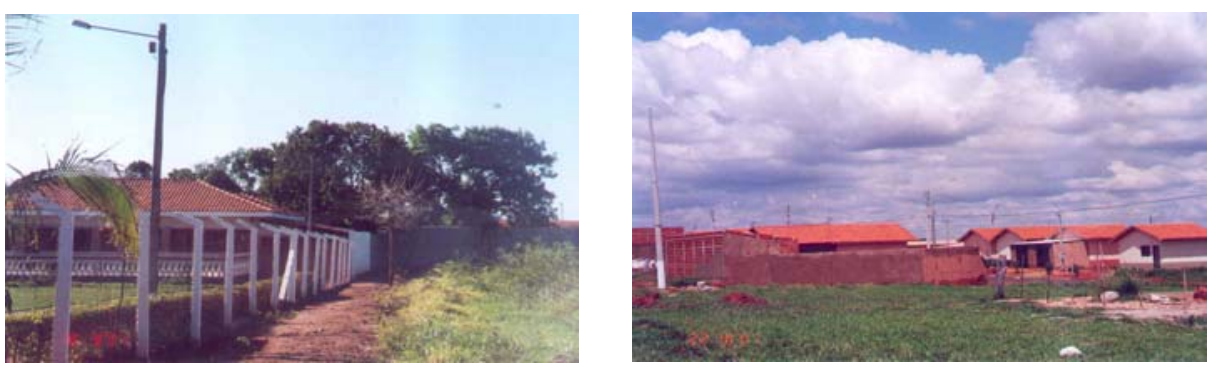

Figura 8.10 - Divisas de propriedades
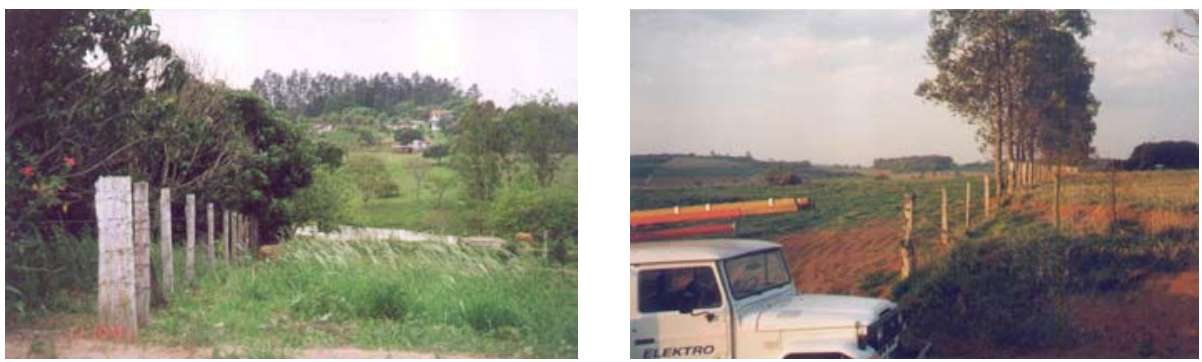

Figura 8.11 - Marco de divisa de municípios
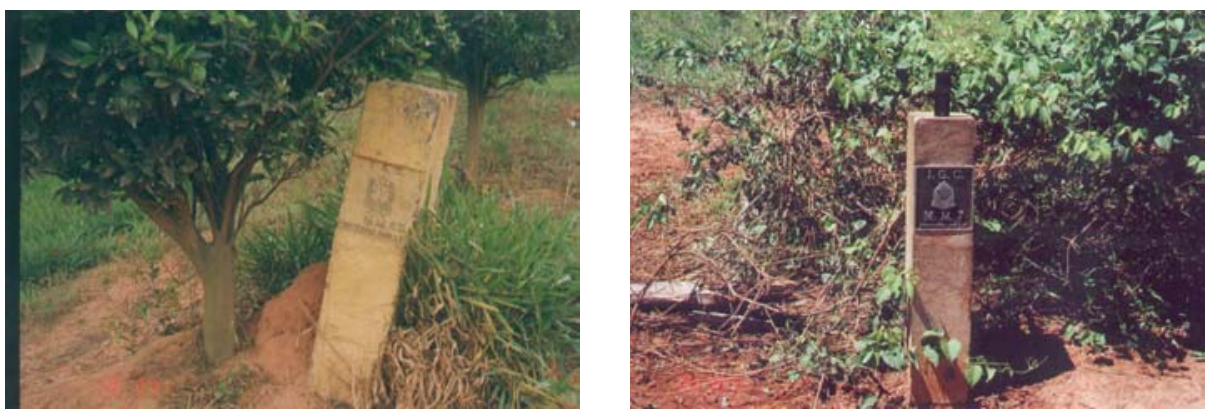
Figura 8.12 - Cruzamentos de redes de distribuição
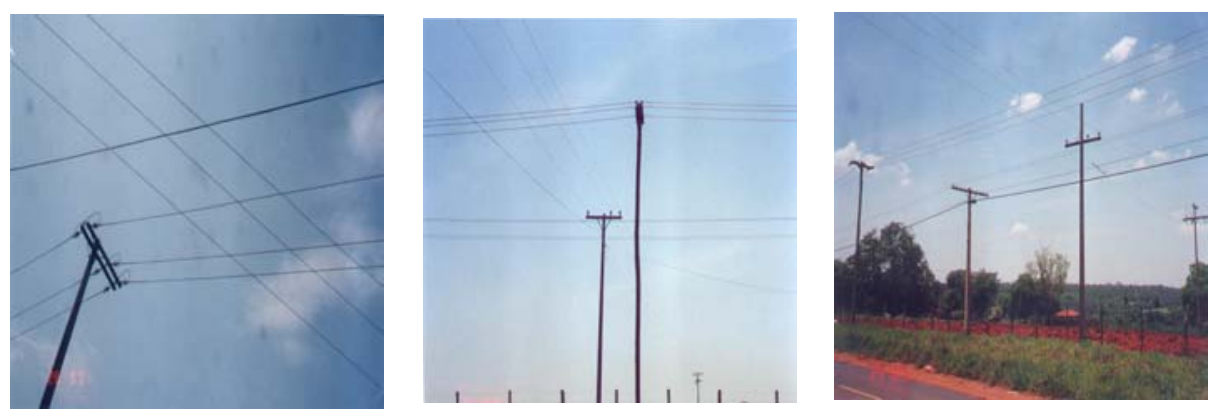

JUCÁ et al. (2003), relatam as seguintes dificuldades encontradas nos levantamentos:

- Difícil acesso aos locais dos levantamentos: existência de obstáculos naturais, pontes quebradas, longas distâncias a serem percorridas.

- Interrupção do trabalho por causa de más condições de tempo.

- Cadastros das redes de distribuição, tanto das cooperativas como das concessionárias, sem um grau adequado de confiabilidade, sendo necessárias análises criteriosas em campo (verificação de proximidades de redes, cruzamentos inexistentes, redes inexistentes, etc.).

- Realização de levantamentos em favelas, plantações clandestinas e desmanches de veículos.

- Existência de propriedades fechadas.

A demarcação foi realizada durante todo o ano de 2002, sendo prevista a conclusão para o início de 2003. Por causa do contingenciamento de recursos que a Aneel sofreu, houve um atraso nessa conclusão. O trabalho de demarcação da última cooperativa restante, a Cedri, está sendo realizado em junho de 2003.

Os relatórios de demarcação foram enviados aos agentes e anexados ao processo administrativo de regularização. As concessionárias CPFL e Elektro contestaram, de modo geral, a arbitragem, mas não ofereceram sugestões ou 
propostas para mudança dos pontos arbitrados. Alguns agentes já estão se antecipando à regularização, trocando ativos onde se indicou necessário.

A CSPE está utilizando os dados da arbitragem para a resolução de conflitos e disputas entre as cooperativas e concessionárias por consumidores. Salvo pequenas alterações pontuais, o trabalho realizado define rigidamente a área de atuação de cada cooperativa, e será utilizado pela Aneel na futura resolução de regularização de cada cooperativa.

\subsection{Conclusões da CSPE sobre o enquadramento das cooperativas de São Paulo}

Em relação ao enquadramento das cooperativas de São Paulo, a CSPE definiu, após o estudo do mercado e do processo administrativo, a seguinte forma de regularização:

- Como permissionárias - 13 cooperativas: CEDRAP, CEDRI, CEMIRIM, CERFRA, CERIM, CERIPA, CERIS, CERMC, CERNHE, CERPRO, CERRP, CERVAM e CETRIL.

- Como autorizadas - 4 cooperativas: CERMESO, CERPAL, CEROC e CERT.

Posteriormente, a Cert se manifestou contrária a essa decisão. Deste modo, o enquadramento está sendo revisto, não havendo uma posição oficial até o momento. 


\section{CAPÍTULO 9 - AS COOPERATIVAS NA SOMBRA}

\subsection{Um modelo perdido no caminho}

O modelo brasileiro de eletrificação rural por cooperativas é um modelo que ficou pelo caminho, no meio-fio.

Apresentou-se, até aqui, a gênese, a expansão, a crise e a consolidação de um modelo. As cooperativas de eletrificação rural foram, desde o início, impostas ao setor elétrico. Este nunca soube como lidar com um ente menor, disperso, mas com grande interlocução política, havendo momentos de interlocução mais íntima com alguns Governos, em especial, Governos de raízes rurais.

O interlocutor das cooperativas sempre foi o Estado, sob a tutela do Estado cresceu, e quando este entrou em crise, também o modelo definhou. Dessa época, restou um corpo de entidades marginalmente pertencentes ao setor elétrico, fora do seu centro decisório.

Quando chegou o momento da grande reestruturação, foi preciso acordar de um certo estágio letárgico. E agora? Como será a inserção nesse novo modelo?

Nesse momento, prevaleceu a velha norma: a interlocução direta com os Poderes. Nos dispositivos legais da reestruturação, as cooperativas deveriam se tornar permissionárias.

Tornar-se permissionária equivale à inserção definitiva no setor elétrico. O Estado fazia reconhecer ao setor a necessidade de incorporar as cooperativas ao seu centro.

Todavia, sempre há coisas mais importantes a decidir. As cooperativas, assim como a eletrificação rural, ficaram à margem do processo de reestruturação. De novo, perdidas pelo caminho. 
Surgem então, para tomar conta de assuntos pelos quais o Estado não tinha mais interesse, as Agências Reguladoras, como entes propagados como descolados do poder político, pairando sobre os setores de infra-estrutura.

Paradoxalmente, a Aneel torna-se o principal meio para que as cooperativas, acostumadas ao trato político do jeito conservador, se "regularizem" num novo contexto.

Há aí um aprendizado. O setor elétrico passa a tentar compreender quem eram aqueles agentes, e as cooperativas a encontrar novas formas de interlocução, menos políticas e mais técnicas.

As próprias cooperativas falavam no novo papel de fazedor de intermediação que a lei conferia à Agência Nacional. Dizia o representante delas:

“- Agora os agentes procurarão aprender o que significa fazer intermediação de conflitos e se prepararão para essa nova e desconhecida fase, com esse novo papel delegado a essa nova instituição; todos terão de aprender a conviver com a intermediação." (STEFANELLO, 1999)

A Aneel é o ponto-chave do processo. A agência assume todos os papéis do Estado, inclusive o de formular políticas, quando este se omite. Vale a máxima: o poder nunca é órfão. Sempre há um ente para exercê-lo, quando outro deixa de fazêlo.

Desse modo, o processo de regulamentação das cooperativas de eletrificação rural padece de idas e vindas. Ora há avanços, ora recuos. Tenta-se juntar duas realidades de cooperativas, do Sudeste/Sul e do Nordeste, numa mesma regulamentação. Cria-se a figura da autorização.

Entretanto, na atividade de regular tudo é novidade. O arcabouço jurídico não é claro, os agentes privados, cooperativas e concessionárias desconfiam da agência, e esta tenta uma regulamentação por demais abrangente.

Os limites de atuação da agência são então mostrados. Enquanto os conflitos se acirram, o processo de regularização se interrompe, até que um novo dispositivo legal, fruto de um processo de mediação, se estabeleça. 
O autor deste trabalho viveu de perto esse último momento, como profissional militante da CSPE. Ao deixar a agência, no início de 2002, tinha certeza que em poucos meses as cooperativas se regularizariam, pondo fim aos desgastantes processos de mediação então em curso.

Porém, tal fato não ocorreu. Até meados de 2003, apenas duas cooperativas, uma do Rio Grande do Sul e outra de São Paulo haviam sido regularizadas, como autorizadas.

Permanece ainda um impasse regulatório importante: a regulação econômica das cooperativas. Este capítulo analisa esse impasse e formula uma proposta de solução de interesse acadêmico, como fruto dos estudos que foram feitos. Como compete à universidade publicar os novos conhecimentos que produz, este documento, meramente como uma contribuição do autor ao debate nacional, a oferece ao leitor, provavelmente outro estudioso do tema.

\subsection{A regulação das cooperativas}

Podemos definir duas dimensões da regulação dos agentes de distribuição de energia elétrica:

- a regulação técnico-comercial: que trata da qualidade do serviço e das relações com os consumidores.

- a regulação econômica: que trata das tarifas e do equilíbrio econômicofinanceiro da empresa.

As duas dimensões só podem se efetivar se houver um ambiente legal previamente definido. $\mathrm{O}$ agente precisa se constituir como ente a ser regulado. Os instrumentos utilizados para isso são, além da base legislativa, formada pelas leis e decretos, outros atos do poder concedente, como portarias e resoluções e os contratos que regem a prestação do serviço por delegação do Estado. 
A discussão feita até agora do processo de regularização das cooperativas prendeu-se, em grande parte, na criação desse ambiente legal. Hoje as cooperativas não são reguladas nem na dimensão técnico-comercial, nem na dimensão econômica. Só passam a ser se, definido o enquadramento legal, assinarem um contrato de adesão à permissão ou receberem um ato autorizativo.

O que se fez até agora foi criar, de modo geral, o arcabouço jurídico que permite o enquadramento. A resolução 012/02 é o ato final dessa construção, que vem desde a década de 1960.

Entretanto, surge um novo desafio: como realizar as regulações técnicocomercial e econômica sobre um agente que nunca esteve sujeito a isto? E mais, como realizar isto considerando o novo ambiente regulatório, criado pela reestruturação do setor elétrico, depois fortalecido, depois conturbado pelo racionamento - quando o regulador foi deixado de lado ostensivamente - depois contestado em essência pelo próprio governo?

Estas questões estão apenas parcialmente respondidas pela agência reguladora. Somente sua resposta completa pode completar o processo de regularização, com a assinatura dos contratos de adesão à permissão e emissão dos atos autorizativos. Hoje, o que impede a Aneel de respondê-las é uma crise de identidade.

\subsection{1 - A regulação técnico-comercial}

As cooperativas de eletrificação rural, como agentes de distribuição de energia elétrica, sempre mimetizaram procedimentos e práticas das concessionárias.

O setor de distribuição, durante muito tempo um ramo menor nos estudos dos sistemas de potência, tem ultimamente adquirido visibilidade e atraído a atenção pela miríade de problemas e soluções novas a enfrentar. Entre os problemas, acaba de surgir a universalização do serviço de eletricidade, uma imposição da lei às concessionárias e permissionárias, a ser também regulada e fiscalizada pela própria Aneel. 
Historicamente, o setor de distribuição tinha uma liderança técnica concentrada nas empresas maiores. As empresas menores, com menor faturamento e menos consumidores, seguiam os rumos traçados por essas empresas líderes.

Durante muito tempo foi assim, e as cooperativas seguiam, um pouco de longe, os avanços tecnológicos.

A privatização e o uso intensivo da Tecnologia de Informação aceleraram processos que já vinham se desenhando desde o começo da década de 1990: a centralização da operação em COD's, a substituição de agências por centros de atendimento telefônico (call-centers), o uso de ferramentas de geoprocessamento, a implantação de ferramentas de gestão e a reorganizações operacionais, com redução drástica de pessoal técnico.

Em conjunto com esses processos, uma nova maneira de atuação do Estado no setor: em lugar de atuação direta e controle dos processos, a regulação indireta dos serviços de empresas privatizadas por indicadores de qualidade. Índices como $\mathrm{DEC}^{18}, \mathrm{FEC}^{19}, \mathrm{DIC}^{20}, \mathrm{FIC}^{21}, \mathrm{TMA}^{22}$, níveis de tensão, indicadores de atendimento comercial, antes restritos às áreas técnicas das empresas, passaram a ser objeto de atenção da alta diretoria e de acompanhamento constante pelos reguladores.

A engenharia da distribuição colocou seus melhores quadros na formulação dessas diretrizes. A Aneel, com forte colaboração da CSPE, inventou as atividades de regulação e fiscalização do setor elétrico. Uma nova cultura, representada por uma nova gama de profissionais, foi sendo introduzida na agência e nas empresas.

\footnotetext{
${ }^{18}$ DEC - Duração Equivalente de Interrupção por Unidade Consumidora: Intervalo de tempo que, em média, no período de observação, em cada unidade consumidora do conjunto considerado ocorreu descontinuidade da distribuição de energia elétrica.

${ }^{19}$ FEC - Freqüência Equivalente de Interrupção por Unidade Consumidora: Número de interrupções ocorridas, em média, no periodo de observação, em cada unidade consumidora do conjunto considerado.

${ }^{20}$ DIC - Duração de Interrupção Individual por Unidade Consumidora: Intervalo de tempo que, no periodo de observação, em cada unidade consumidora, considerada individualmente, ocorreu descontinuidade da distribuição de energia elétrica.

${ }^{21}$ FIC - Freqüencia de Interrupção Individual por Unidade Consumidora: Número de interrupções ocorridas, no periodo de observação, em cada unidade consumidora, considerada individualmente.

${ }^{22}$ TMA - Tempo Médio de Atendimento: reflete o tempo médio que uma determinada concessionária gasta para restabelecer o fornecimento de energia após a ocorrência de um defeito.
} 
Já foi mostrado como, em São Paulo, esse processo influenciou as cooperativas de eletrificação rural. A CSPE foi pioneira na aproximação a elas, mantendo um relacionamento constante que propiciou a ambas as partes um reconhecimento mútuo dos limites e das necessidades de atuação.

Se, para as concessionárias, o processo de regulação foi uma novidade, para as cooperativas é algo ainda mais novo, e precedido de um requisito básico: a definição da área de atuação.

O processo de definiçãa de áreas, já descrito, envolve o reconhecimento da atuação da cooperativa naquela área geográfica, em conjunto com os deveres da prestação do serviço público. Em São Paulo, o processo de definição está quase concluído e exigiu a arbitragem da CSPE, que não tinha essa intenção no início, imaginando que as partes (concessionárias e cooperativas) poderiam negociar um entendimento.

A superação desse obstáculo, que já vem se arrastando desde o ano de 1999, permite a regularização legal da cooperativa como permissionária ou autorizada. Em seguida, haverá uma série de desafios a serem vencidos pelas cooperativas de eletrificação rural para se adequar ao ambiente regulatório técnico-comercial.

De certo modo, as cooperativas de eletrificação rural de São Paulo já vêm realizando ações no sentido de se adequar aos novos tempos. Muitas já apresentam índices como DEC e FEC, e mantêm um relacionamento comercial com o consumidor/cooperado muito semelhante às concessionárias. Ainda, uma parte usa sistemas de gerenciamento de rede e procura implantar práticas de gestão mais modernas.

O desafio nessa área será reduzir a assimetria encontrada nas cooperativas. As maiores, com maior geração de recursos, têm uma estrutura mais consolidada. Enquanto isso, as menores realmente irão necessitar de uma atualização, que só virá com novos investimentos. Nesse sentido, a organização delas em uma federação contribui para a disseminação de exemplos positivos, apesar disso não ser suficiente. 
Os principais pontos que deverão ser enfrentados são:

- Adequação dos procedimentos comerciais à Resolução 456/00, principalmente nos prazos e taxas cobrados do consumidor/cooperado.

- Adequação dos registros contábeis ao Plano de Contas do Setor Elétrico.

- Avaliação dos ativos.

- Apuração e controle de índices técnicos de qualidade de fornecimento, em relação à continuidade do serviço e níveis de tensão.

- Adequação de procedimentos técnicos de modo a refletir as exigências regulatórias.

Pode-se dizer que, no meio dos que militam na regulação, entre os que se envolveram com o problema das cooperativas, ainda não surgiu uma voz que afirme que haja chance de não acontecer tal ajuste, ou que elas tenham dado sinal indicativo de falta de capacidade de se ajustar à regulação técnica.

Ao autor não resta dúvida que as cooperativas de eletrificação rural conseguirão se ajustar ao aparato regulatório técnico-comercial. Este não se constitui em obstáculo determinante, que impeça sua regularização, sendo até mesmo desejado pelo órgão regulador, que finalmente poderá realizar uma fiscalização efetiva e exercer seu dever de proteger o consumidor. É necessário, porém, que haja duas condições principais: que se estabeleça uma transição no processo (que pode ser negociada com cada cooperativa, dependendo do estado atual) e que haja recursos financeiros suficientes, tanto para sua modernização, como para a participação no processo de universalização.

Não há discordância nesse ponto. A regulação técnico-comercial não é dificuldade intransponível para as cooperativas de eletrificação rural e é um grande desejo do consumidor, que finalmente pode ser considerado equiparado aos demais consumidores do setor elétrico. O impasse, hoje, está na regulação econômica. 


\subsection{2. - A regulação econômica}

A teoria da regulação é, em grande parte, uma teoria econômica. Mecanismos de regulação por incentivos tentam introduzir elementos de competição em setores onde isto não é possível, por constituírem monopólios naturais, como a distribuição de energia elétrica.

Uma crise na área econômico-financeira de uma empresa de distribuição se reflete diretamente nos investimentos e na qualidade do serviço. Se por um lado as dificuldades técnicas podem de algum modo ser contornadas, mesmo com falta de investimentos, as dificuldades financeiras só se resolvem com mais recursos, via aumento de tarifas ou empréstimos. Esta tem sido a realidade das empresas nos últimos anos.

Os pontos mais questionados do processo de reestruturação do setor elétrico pertencem à área econômica: os preços mínimos de privatização, o uso do IGP-M na correção dos contratos, a inoperância do MAE, o cálculo dos preços da energia, a estrutura tarifária e, mais recentemente, a revisão tarifária.

Com as cooperativas não é diferente. Desde os estudos da Coopers \& Lybrand tem se tentado formas de resolver a equação financeira das permissionárias.

Um ponto-chave quando o Estado delega, por meio de concessão ou permissão, a um terceiro a tarefa de realizar um serviço público é o chamado equilíbrio econômico-financeiro. Em troca do atendimento exclusivo de um mercado com tarifas reguladas, o Estado se compromete a manter o contrato equilibrado, isto é, que a arrecadação da concessão permita a prestação adequada do serviço, o investimento na expansão e atualização das instalações e a perspectiva de lucro nas operações. Este lucro pode ser mais ou menos livre. No regime atual, o Estado garante uma margem mínima, e a empresa tem incentivos para aumentá-la por meio da melhoria de produtividade e eficiência.

As cooperativas de eletrificação rural, que antes de se regularizar são apenas cooperativas, não são outra coisa, e nem são permissionárias ou autorizadas, 
mantém-se equilibradas economicamente através de um desconto de $50 \%{ }^{23}$ na compra de energia e demanda e com a isenção de pagamento de multas por ultrapassagem de demanda. O desconto é histórico, tendo até sido maior nas décadas de 70 e 80, e necessário pois, apesar de ser constituído por público indistinto, o mercado das cooperativas, futuras permissionárias ou autorizadas, possui uma parcela significativa de consumidores pertencentes à classe rural, além de ser pequeno em relação ao das concessionárias. Por esse motivo, além de atender a público pobre, não tem escala em suas atividades, possuindo um custo maior por MWh vendido ou por consumidor atendido do que uma concessionária que, além de áreas rurais, atende também núcleos urbanos densos. Mesmo com o desconto, algumas cooperativas têm preços bastante superiores aos das concessionárias locais, gerando grande insatisfação entre os cooperados.

O mecanismo de desconto, instituído desde a formação das cooperativas, não foi, em muitos casos, suficiente para produzir preços adequados aos consumidores, e nem levou em consideração os diferentes estágios de desenvolvimento do mercado das cooperativas de eletrificação rural. Foi uma política cômoda, que se impôs ao longo do tempo e, no momento da regularização, tem que ser revista. Mas o que colocar no lugar?

Numa concessão de serviços públicos, dois princípios básicos de regulação econômica devem ser seguidos:

- O princípio do equilíbrio econômico-financeiro do contrato de concessão (ou de permissão), cujo conceito já foi abordado.

- O princípio da modicidade tarifária, descrito assim por PORTO NETO, apud GROTTI (2000):

"o principio da modicidade da contraprestação devida pelos usuários na fruição dos serviços públicos implica o dever do Estado de fixá-la em valor que viabilize o acesso da coletividade ao serviço e que seja compatível com a natureza social do serviço" (PORTO NETO, apud GROTTI, 2000)

\footnotetext{
${ }^{23}$ Exceto no Rio Grande do Sul. Nesse estado, existem três faixas de desconto tarifário, de 62\%, 70\% e $80 \%$.
} 
A regulação procura equilibrar esses dois conceitos, através da fixação de tarifas aos usuários do serviço de energia elétrica que preserve tanto o lado da concessionária quanto o do consumidor.

No caso das cooperativas de eletrificação rural, pelas características do seu mercado, se impostas as mesmas condições da concessionária (compra de energia sem desconto e encargos setoriais), corre-se o risco de duas coisas: ou a tarifa será demasiado alta, rompendo o princípio da modicidade tarifária, ou não haverá equilíbrio econômico-financeiro da permissão, impedindo a cooperativa de atuar. A conta não fecha, e a solução é apenas uma: subsídio.

Nas concessionárias de distribuição, a classe de consumo rural já dispõe de descontos nas suas tarifas, pago pelas demais classes de consumo através de mecanismos de subsídios cruzados. O desconto oferecido hoje às cooperativas já é uma forma de subsídio, pago pelos consumidores da concessionária onde a cooperativa está conectada.

Na Resolução 333/99, no Art. 27, a Aneel definiu a necessidade de introduzir mecanismos compensatórios para as cooperativas de eletrificação rural, impondo a si um prazo para definição desses mecanismos:

“Art. 27. A Aneel estabelecerá, no prazo de até cento e oitenta dias, regulamentação específica definindo mecanismos compensatórios que considerem a dimensão e a estrutura dos mercados atendidos pelas permissionárias, visando permitir a prestação de serviço adequado."

Desde que surgiram os primeiros debates sobre regularização, as cooperativas estão em grande expectativa em relação a esses mecanismos. Nas reuniões realizadas entre as cooperativas de São Paulo e a Aneel, esse tema, além dos esclarecimentos sobre permissão ou autorização, era sempre questionado. A Aneel não tinha respostas conclusivas, afirmando que a questão estava sendo estudada.

Durante o ano de 2000, a Aneel iniciou alguns estudos nessa área. Foi pedido às cooperativas um documento denominado MAEP (Modelo de Avaliação Econômica de Permissionárias), visando a coleta de dados para estudo das isenções que poderiam ser feitas. É interessante notar que houve relutância da parte das 
cooperativas de São Paulo em fornecer os dados. Julgavam elas que a Aneel, com o documento, já definiria as tarifas da cooperativa, fato que só vai ocorrer após a formalização da regularização. Ainda havia uma grande desconfiança, por parte das cooperativas, do órgão regulador. Essa tentativa de "esconder o jogo" mostra que a característica de resolver politicamente os problemas, fruto do mandonismo já citado, se fazia revigorada em tempos de agência reguladora.

Por fim, foram enviados os dados pedidos. Nesse tempo, as cooperativas, assessoradas por uma empresa de consultoria, estavam se reorganizando contabilmente. Em quase todas foram feitas reavalização de ativos e tentou-se iniciar a adequação da contabilidade ao Plano de Contas do Setor Elétrico.

A equipe técnica da Aneel realizou alguns estudos, com base nos dados disponíveis, traçando alternativas. O autor não teve acesso aos estudos mas, em contatos informais, soube que foram aventados mecanismos como a isenção de encargos setoriais (RGR, $\mathrm{CCC}^{24}$, TFSEE ${ }^{25}$, ONS, CFURH ${ }^{26}$, uso da Rede Básica, encargos de Itaipu, $\mathrm{CDE}^{27}$, entre outros) e redução das tarifas de suprimento. As propostas chegaram a ser levadas à diretoria, mas nenhuma delas foi aprovada definitivamente.

Nessa época, já se iniciava o questionamento jurídico da Resolução 333/99. Esse fato, aliado à falta de informação das cooperativas em geral ${ }^{28}$, seguramente contribuiu para a indefinição.

Além do questionamento sobre as figuras da permissão e autorização de maneira ampliada, começaram a surgir dúvidas jurídicas a respeito da competência da Aneel em definir os mecanismos compensatórios. Chegou-se, dentro da própria agência, à conclusão de que, sem uma lei que autorizasse explicitamente a Aneel a definir esses mecanismos, eles não poderiam ser estabelecidos por ato da agência.

\footnotetext{
${ }^{24}$ Conta de Consumo de Combustíveis.

${ }^{25}$ Taxa de Fiscalização do Serviço de Energia Elétrica.

${ }^{26}$ Compensação Financeira pelo Uso dos Recursos Hídricos.

${ }^{27}$ Conta de Desenvolvimento Energético.

${ }^{28}$ Lembrando que as únicas agências estaduais que trabalhavam com regularização de cooperativas de eletrificação rural eram a de São Paulo e do Rio Grande do Sul. A Aneel possui uma equipe reduzida
} 
Começam aí as discussões sobre o alcance das ações da Aneel nessa questão, origem do impasse atual. Há algumas controvérsias: quais as responsabilidades e competências exatas da agência? Até que ponto ela pode ir, sem ter suas ações questionadas pelo Judiciário, nem invadir competências de governo?

Quando da revisão da Resolução 333/99, que resultou na Resolução 012/02, essa posição foi explicitada. A Resolução 012/02 condicionou a definição dos mecanismos compensatórios a uma autorização legal, definindo, em seu Art. 25:

“Art. 25. A Aneel estabelecerá, no prazo de até noventa dias após a edição de lei autorizativa, regulamentação especifica definindo mecanismos compensatórios que considerem a dimensão e a estrutura dos mercados atendidos pelas permissionárias, visando permitir a prestação de serviço adequado."

No processo negocial que levou à publicação da Resolução 012/02, a Aneel assumiu o compromisso de atuar para que, dentro do processo de revitalização do setor elétrico, a autorização legal fosse contemplada.

Assim, na discussão da Medida Provisória 14, que definiu as bases para o Acordo Geral do Setor com as compensações às empresas decorrentes do racionamento, o relator no Congresso acrescentou itens referentes às cooperativas que incluem a autorização para a Aneel definir os mecanismos compensatórios. A Lei 10.438, originada desta Medida Provisória, autorizou então a Aneel a fazer essa definição.

A Aneel sempre cai em armadilhas quando fixa prazos para suas ações. Era de se esperar que, em 90 dias a partir de abril de 2002, quando a Lei 10.438 foi publicada, houvesse a definição dos mecanismos compensatórios. Entretanto, isso não ocorreu. 


\subsection{Um impasse institucional}

A Lei 10.438 define explicitamente, em seu Art. 17, que entre as competências da Aneel está:

“Art. 17. (...)

$X I$ - estabelecer tarifas para o suprimento de energia elétrica realizado às concessionárias e permissionárias de distribuição, inclusive às Cooperativas de Eletrificação Rural enquadradas como permissionárias, cujos mercados próprios sejam inferiores a $300 \mathrm{GWh} / a n o$, e tarifas de fornecimento às Cooperativas autorizadas, considerando parâmetros técnicos, econômicos, operacionais e a estrutura dos mercados atendidos;"

O caráter geral de uma lei aprovada no Congresso Nacional é reduzido depois por atos do Poder Executivo, que detalham, através de Decretos, aspectos da lei. No setor elétrico, desde a criação da Aneel, havia uma estreita colaboração entre o Poder Executivo (Ministério de Minas e Energia) e a agência, que sugeria disposições nos Decretos que depois eram ainda mais detalhadas por meio de Resoluções.

Assim, o Decreto Federal $n^{\circ} 4.541$, de 23/12/02, entre outros assuntos, direciona um pouco mais como devem ser as tarifas de suprimento para as permissionárias, nos artigos 51 e 52 . O artigo 50 repete o texto da Lei 10.438, acima.

"Art. 51. As concessionárias, permissionárias e cooperativas referidas no Art. 50 deverão celebrar contratos distintos para a conexão, uso dos sistemas de transmissão ou distribuição e compra de energia elétrica.

Parágrafo único. Na definição do valor das tarifas para os contratos de conexão e de uso dos sistemas de transmissão ou distribuição de que trata este artigo, serão consideradas as parcelas apropriadas dos custos de transporte e das perdas de energia elétrica, bem como os encargos de conexão e os encargos setoriais, conforme regulamentação existente, admitida uma redução, quando necessária, em relação às tarifas de transmissão e de distribuição.

Art. 52. As tarifas de energia elétrica aplicáveis aos contratos de venda para os agentes de que trata o Art. 50 poderão ser estabelecidas na forma monômia ou binômia e serão determinadas, até a data contratual dos respectivos reajustes ou revisões tarifárias das concessionárias de distribuição vendedora, com base no custo da energia disponivel para venda, acrescido do custo de comercialização e, onde couber, de encargos setoriais e tributos. 
$\S 1^{\circ}$ A Aneel poderá definir desconto sobre as tarifas que trata o caput, aplicáveis às permissionárias e autorizadas citadas no Art. 50, quando necessário para garantir a mesma condição econômica dos contratos de suprimento atuais.

$\S 2{ }^{\circ} \mathrm{O}$ desconto mencionado no $\S 1^{\circ}$ será fixado de forma decrescente, a cada ano e para cada permissionária, de modo a estimular o incentivo à eficiência."

Esses dispositivos trazem os seguintes pontos importantes:

- Há uma equiparação no tratamento de pequenas concessionárias (com mercado abaixo de $300 \mathrm{GWh} / \mathrm{ano}$ ), permissionárias e autorizadas, nos seguintes aspectos, que não valem para as cooperativas não regularizadas:

- Obrigação de firmar contratos distintos de uso do sistema, conexão e compra de energia.

- Tais contratos são totalmente regulados pela Aneel, inclusive quanto aos valores.

- Em conseqüência, não há, para esses agentes, como participar do mercado livre de energia.

- Clarifica-se qual foi a opção para os mecanismos compensatórios para as cooperativas: o desconto nas tarifas de suprimento, uso do sistema e conexão, mantendo-se o custo de comercialização e todos os encargos setoriais. Este desconto deve garantir às cooperativas no mínimo a mesma condição econômica existente hoje, e deve ser reduzido a cada ano, de modo diferenciado para cada permissionária.

Em maio de 2003, a Aneel emitiu a Resolução 236/03, disciplinando as regras para os contratos das pequenas concessionárias. Nesta Resolução a Aneel define, para as 18 concessionárias de distribuição enquadradas nesta categoria (algumas com mercado inferior às maiores cooperativas), o(s) fornecedor(es) de energia com quem a concessionária deve firmar os contratos. Esses contratos são de compra de energia (CCE), conexão ao sistema de distribuição e/ou transmissão (CCD ou CCT) e de uso 
do sistema de distribuição e/ou transmissão (CUSD ou CUST). A tarifa de energia, constante do CCE, deverá ser fixada pela Aneel, que não o fez até o momento.

Essa regulamentação para as pequenas concessionárias foi precedida pela Audiência Pública $n^{\text {o }}$ 029, realizada no fim de 2002. Apesar de faltar ainda o principal ponto, que é a definição da tarifa de energia, parece estar bem encaminhada.

Permanece, entretanto, a indefinição sobre as cooperativas. Passados três anos e meio do primeiro compromisso assumido pela Aneel, não há sinal à vista de definição. As razões disso devem ser, de novo, procuradas no contexto político.

O novo governo que tomou posse em 2003 assumiu com um discurso bastante crítico às agências reguladoras, particularmente as do setor de infraestrutura. Julgam os novos governantes que as agências têm extrapolado os seus papéis de reguladores e fiscalizadores e implementado políticas de cunho próprio, cuja formulação deveria ser função dos Ministérios. Além disso, como os demais órgãos federais, a Aneel teve grande parte do seu orçamento contingenciado, afetando o repasse de recursos às agências estaduais e, conseqüentemente, o processo de regularização de cooperativas.

Por conta disso, as agências, incluindo a Aneel, têm assumido uma atitude defensiva. O autor participou, em fins de maio de 2003, do III Congresso de Regulação de Serviços Públicos Concedidos, promovido pela Associação Brasileira de Agências de Regulação (ABAR), onde pôde constatar esse fato. Um dos principais eventos foi o lançamento de um livreto intitulado "Agências Reguladoras, Instrumentos de Fortalecimento do Estado", que procura ressaltar a importância da existência das agências reguladoras como órgãos autônomos, embora necessitem de aperfeiçoamentos.

Nesse mesmo fórum, testemunhou a importância que o tema da eletrificação rural passou a ter. A ele foram dedicados um painel, sobre universalização de serviços públicos, e duas oficinas, uma também sobre universalização e outra sobre 
cooperativas de eletrificação rural. Em ambas, concluiu-se que a ABAR deveria formar grupos de discussão sobre os temas.

O Congresso de Regulação é um fórum de debates. Lá estavam os agentes, concessionárias, cooperativas, poder público, além do regulador - o representante da Aneel - e a comunidade de pesquisadores.

Esta última manifestava certo desconforto com o andar da carruagem. Houve a Resolução 012/02, o início dos trabalhos de demarcação de áreas de atuação, a Lei 10.438 , por que não há a regularização das cooperativas? Que entraves impedem a imediata definição dos procedimentos e das tarifas de suprimento para as cooperativas?

Formalmente, o representante da área de regulação econômica da Aneel respondeu o que vai registrado a seguir:

- A intenção inicial da agência era consolidar, em uma única norma, a regulamentação das tarifas de suprimento para pequenas concessionárias e das cooperativas.

- Essa regulamentação teria que estabelecer uma estrutura tarifária para as cooperativas de eletrificação rural de tal forma que se garantisse o equilíbrio econômico-financeiro e tarifas módicas. Para isso, necessariamente deveria haver algum tipo de subsídio nas tarifas de suprimento.

- Outro entrave é a dificuldade de obtenção de informações das cooperativas para realização de estudos econômicos, pela sua inadequação à estrutura contábil do setor elétrico.

- A Aneel não pode criar subsídios, e então não pode definir já as tarifas de suprimento. Somente o Congresso, através de uma Lei (não pode ser via Decreto Federal) pode fazer isso, seja através da criação de um novo fundo ou conta, seja através do deslocamento de recursos dos fundos existentes. 
Outra intenção da agência é estabelecer, já de início, uma estrutura tarifária que produza o equilíbrio da permissão, para evitar situações como da Enersul, que obteve um reposicionamento tarifário ${ }^{29}$ de $42,26 \%$, na mais recente revisão tarifária, bastante superior à correção das outras concessionárias. A razão disso é que, no momento da privatização e assinatura do contrato de concessão, a empresa não foi submetida a ações que equilibrassem sua estrutura tarifária, obrigando agora a uma correção maior que a esperada. Provavelmente, durante este período, a empresa não obteve uma remuneração adequada ${ }^{30}$. Um exemplo oposto a esse é o da Eletropaulo, que teve um reposicionamento tarifário de $10,95 \%$.

Pelo relato obtido, depreende-se que a área de regulação econômica da Aneel entende que o subsídio para as cooperativas de eletrificação rural deve ser explicitado em forma de lei, e formatado de tal forma que todos os consumidores do setor arquem com este encargo. Até que seja promulgada esta lei, não é possível definir a tarifa de suprimento das cooperativas e, em conseqüência, não é possível emitir os atos de regularização.

No mesmo evento houve uma sessão de debates sobre as cooperativas de eletrificação rural. Estava presente um representante do MME, a quem foi feita a mesma indagação, relatando-se a visão da Aneel. A visão do Ministério é que não são necessários novos comandos legais, pois os existentes permitem que a Aneel defina as tarifas de suprimento para as cooperativas. Com isso, os consumidores da concessionária a que a cooperativa está conectada continuariam a $\operatorname{arcar}$ com o subsídio. Apenas deve-se rever o percentual de desconto, para adaptá-lo a cada situação específica de cooperativa.

Uma visão semelhante a esta também existe dentro da Aneel. Os condutores do processo de regularização, pertencentes à superintendência de concessões, entendem que é urgente e necessária a imediata conclusão da regularização das

\footnotetext{
29 O reposicionamento tarifário é o valor de correção que deve ser aplicado às tarifas da concessionária para manter o equilíbrio econômico-financeiro. Ele é calculado nas revisões tarifárias periódicas feitas pela Aneel relativas às concessionárias distribuidoras. Em 2002 e 2003, a maioria das distribuidoras está passando por esta revisão.
} 
cooperativas de eletrificação rural, sem a qual há o risco de se perder parte do processo e acirrar conflitos. Todos os outros procedimentos, inclusive as minutas dos documentos legais necessários (resoluções, pareceres, contratos) já estão definidos, faltando apenas definir as tarifas.

As cooperativas, por outro lado, só admitem ser regularizadas se o órgão regulador fizer a definição das tarifas de suprimento.

A partir dessas constatações, fica clara a existência de um impasse institucional, que trava o processo de regularização: o órgão regulador possui duas visões diferentes sobre a conclusão do processo, vivendo uma crise de identidade. A diretoria da Aneel será chamada a definir o impasse. Há o risco de optar pela visão da regulação econômica, gerando outro impasse com o governo.

Assim, do modo como hoje ele se apresenta, não há se sabe se o impasse será superado rapidamente. Isso é extremamente preocupante, pois a conseqüência é um grande prejuízo ao consumidor e ao cidadão ainda não-conectado.

\subsection{O Brasil regulado, o Brasil não-regulado}

A incorporação definitiva das cooperativas de eletrificação rural ao setor elétrico é uma política pública que vem sendo realizada desde 1995. O processo de regularização, nesse período, viveu várias crises, tendo superado, com dificuldade, quase todas. Hoje, vive-se outro impasse, que tem a tendência de atrasar ainda mais a conclusão do processo. No entanto, os avanços feitos até o momento tornam particularmente grave o atual, pelas conseqüências que o atraso traz, principalmente nos estados onde o processo está mais avançado.

Em São Paulo, após um grande esforço da CSPE/Aneel, cooperativas e concessionárias, dando seguimento ao trabalho que começou com as ações dos pesquisadores da área de energia da USP e da Unesp, foi lograda a demarcação dos

\footnotetext{
${ }^{30}$ Não se discute aqui se a metodologia de cálculo dessa remuneração pela Aneel é adequada ou não, e se ela pode ser aplicada também às cooperativas de eletrificação rural. Apenas constata-se que é a mesma para todas as concessionárias que estão passando pelo processo de revisão tarifária.
} 
limites da concessionária. Esta demarcação tem servido de base para que a agência decida disputas por consumidores, fato bastante freqüente.

A demarcação, embora não tenha valor legal, pois ainda não foi consolidada em ato oficial da Aneel, tem valor de fato, pois foi informada à cooperativa e às concessionárias respectivas, foi anexada ao processo administrativo e está sendo utilizada na resolução de conflitos entre os agentes. Se fosse necessária a publicação hoje de uma resolução de regularização, esta seria a área constante do ato oficial.

A demarcação do limite da concessionária cria a área da cooperativa. Quem demarcou o limite foi o regulador. Logo, quem criou a área da cooperativa, de fato, foi a ação do regulador. A cooperativa ficou conhecida pelo regulador, que the deu uma área para atuar.

A cooperativa de eletrificação rural, reconhecida em sua existência pelo arcabouço regulatório atual, foi reconhecida como cooperativa de eletrificação rural e não como permissionária ou autorizada. Ela não é permissionária, ela é só cooperativa.

É a situação atual. Hoje, ela não tem as obrigações que teria a permissionária. O que a lei obriga a permissionária não é obrigação da cooperativa. É o paradoxo do regulador de cooperativa.

Esta à margem da regulação. Vive à sombra. Continua vivendo à margem, agora reconhecidamente à sombra da lei. O Estado deixa uma área fora do alcance da Lei de Concessões.

A tese que se quer demonstrar é que o ato oficioso do regulador ao demarcar os limites da área de atuação das cooperativas de eletrificação rural cria uma situação de haver áreas de serviço público de eletricidade não regulado. Configura-se assim, nestas áreas, a criação de um monopólio desregulado, onde um agente privado presta serviço público sem nenhuma norma que o regule, com a anuência do órgão regulador. 
Formalmente, é uma situação provisória, esperando que aconteça uma suposta regularização rápida das cooperativas. No entanto, a persistência do atual impasse traz vantagens à cooperativa. Todavia, não interessa ao consumidor, nem à concessionária, nem ao órgão regulador.

Tampouco interessa ao cidadão que ainda não tem luz.

Hoje a cooperativa, futura permissionária já com área demarcada, vive uma situação bastante cômoda. Pode explorar um serviço de forma monopolista, sem nenhuma contrapartida ao Estado e sem a ameaça da concessionária. Uma situação perigosa, que pode servir de tentação para abusos de mercado, tanto mais possíveis quanto por mais tempo ela persistir.

Sempre haverá, nesse caso, a opção de extinguir compulsoriamente a cooperativa e a concessionária local encampar o serviço. Na prática, porém, essa opção já não existe para o órgão regulador.

Se a extinção compulsória de uma cooperativa de eletrificação rural sempre é difícil, pois movimenta forças que vão além de suas organizações específicas, incluindo todo o sistema cooperativista, com grande força política, extinguir uma cooperativa prestes a se regularizar como permissionária, e que só não é regularizada por causa de uma controvérsia do próprio órgão regulador é um enorme contrasenso, mesmo numa situação limite.

Não se afirma que as cooperativas de eletrificação rural vão praticar abusos. Não há, inclusive, sinais que elas estejam fazendo ou vão fazer isso. E o que se espera é que não o façam. No entanto, é um risco muito grande para o serviço público a persistência desse quadro.

Não é essa a tese. A tese é que elas estão vivendo sem regulação, o que fere o espírito da reforma do setor elétrico. O que fere o espírito da lei.

Situação ainda mais crítica vive o cidadão rural sem luz. Na concessionária, está em curso o processo de universalização, pelo qual cada futuro consumidor terá acesso à eletricidade sem custos, conforme se discutirá à frente. Estão estipuladas 
datas para que cada concessionária e permissionária apresente seus planos de universalização, com metas de ligação. No Brasil, até 2025 e, em São Paulo, até $2008^{31}$ todo o território deverá estar atendido, e o Ministério de Minas e Energia pretende reduzir ainda mais estes prazos.

Nada disso vale para a cooperativa, na situação de hoje. O cidadão sem luz ainda tem que arcar com os custos de sua ligação e não tem perspectivas de prazo para ser atendido. A Resolução Aneel 223/03, publicada no final de abril de 2003, e que também será discutida mais à frente, exclui textualmente as áreas das cooperativas de eletrificação rural ainda não regularizadas do processo de universalização do atendimento:

"Art. 16. Excluem-se das condições de atendimento estabelecidas nesta Resolução os seguintes casos:

\section{(...)}

IV - áreas em processo de regularização segundo Resolução Aneel $n^{\circ} 12$, de 11 de janeiro de 2002."

Este problema já está acontecendo. No Litoral Sul paulista, um consumidor, que poderia ser ligado de graça se estivesse na área da Elektro, é obrigado a pagar para se conectar à CEDRI. Fatos como esse passarão a ser cada vez mais freqüentes. Como explicar a um cidadão que seu vizinho, a poucos metros, pode ser atendido gratuitamente enquanto ele é obrigado a pagar pela extensão da rede?

Situações assim podem criar tensão para as próprias cooperativas e conflitos, agravando os já existentes, com conseqüente insatisfação dos consumidores e sobrecarga para o órgão regulador, que é obrigado a encontrar uma solução particular para cada caso.

O corolário da tese é que a persistência do impasse cria, então, dois Brasis diferentes no que se refere ao serviço de energia elétrica. O Brasil regulado, onde existe, depois de anos, até perspectiva de acesso universal ao serviço, e o Brasil que corre o risco de ficar no escuro.

\footnotetext{
${ }^{31}$ Em São Paulo, 93,5 \% dos municípios têm como prazo máximo o ano de 2004.
} 
Outro corolário é que as cooperativas, até pelo atavismo herdado dos imperiais trisavôs das lideranças rurais, os coronéis que Maria Sylvia Carvalho Franco (1997) afirma terem se acostumado a querer mandar no Estado em benefício próprio, encontrarão um espaço político para usar o tempo prolongado de transição para tentar a captura do regulador. É provável que isto já esteja acontecendo.

A superação do impasse, com a imediata regularização das cooperativas de eletrificação rural interessa, agora mais do que nunca, ao cidadão rural.

\subsection{Proposta de ação}

Este trabalho identificou um problema e aplicou o método cientifico em sua análise. Primeiramente, procurou o conhecimento da situação. Como segunda etapa metodológica, interpretou o problema e demonstrou a tese de que o regulador, por seus atos - ou, pelo atraso de atos regulatórios - criou áreas sem regulação. Como ato final da aplicação da metodologia cientifica, o autor, academicamente, propõe ações para a solução do problema analisado.

Qualquer proposta a ser estudada deve ter como objetivo central a regulamentação das cooperativas de eletrificação rural no menor tempo possível, para por luz no obscuro quadro descrito.

Deve também buscar o equilíbrio, tanto entre os agentes, quanto dentro da agência. Há nítidos sinais que, hoje, a superintendência que comanda o processo de regularização o tem como urgente e prioritário, ciente dos problemas existentes. Já a de regulação econômica, talvez por estar atarefada com os densos processos de revisão tarifária, vê o tema com os olhos menos preocupados.

A busca de equilíbrio, aliás, é um dos princípios da função reguladora. A própria Aneel o reconhece, quando proclama sua missão:

"Proporcionar condições favoráveis para que o desenvolvimento do mercado de energia elétrica ocorra com equilibrio entre os agentes e em benefício da sociedade."(Aneel, 2003) 
Dado que o impasse é na questão da fixação do subsídio nas tarifas de suprimento, a sua superação consiste em fazer essa fixação, com alguns condicionantes.

Há três formas possíveis de se dar um subsídio, considerando quem acaba pagando por ele:

1. Aquele que é pago pelo contribuinte: nesse caso os recursos vêm do Tesouro Nacional. O autor considera que essa forma, além de impraticável, é injusta. É impraticável porque o Estado tem feito um grande esforço de ajuste fiscal via redução de despesas, com conseqüências inclusive sobre a Aneel, que teve grande parte de seus recursos contingenciados. Requerer, nessa situação, subsídios do Tesouro para as cooperativas de eletrificação rural não parece razoável. É injusta porque o setor elétrico gera recursos suficientes até para subsidiar grandes indústrias de alumínio. Porque não o mesmo para as cooperativas de eletrificação rural como, aliás, já é feito hoje?

2. Aquele que é pago por todos os consumidores de energia: nesse caso, cada consumidor, em sua conta de energia, paga uma parcela que vai para os encargos setoriais, contas ou fundos. Pode-se criar uma nova contribuição ou deslocar recursos das já existentes. Em ambos os casos é necessária uma lei autorizativa.

3. Aquele que é pago pelos consumidores de uma concessionária específica: nesse caso, algumas classes de consumidores pagam a mais do que deveriam, para subsidiar outras classes. Isto é o que ocorre hoje nas concessionárias a que as cooperativas de eletrificação rural estão conectadas.

O primeiro passo para uma solução é definir que tipo de subsídio usar. Embora o autor concorde que o mais justo seja o segundo tipo, repartindo-se o ônus com todos os consumidores, como a regulação econômica deseja, o momento exige que se use o terceiro tipo, com a seguinte argumentação:

- Os dispositivos legais existentes são suficientes para exercer imediatamente essa opção. 
- As pequenas concessionárias, equiparadas às permissionárias na Lei 10.438 e no Decreto 4.541/02, tiveram sua regulamentação baseada nesse modelo.

- É o que está sendo utilizado atualmente. Persistir com ele gera uma situação neutra, sem grandes modificações na estrutura existente. Provavelmente irá gerar alguns protestos das concessionárias, que têm a expectativa de se "livrar" desse consumidor que hoje dá prejuízo (embora compensado pelos outros consumidores).

Decidido o tipo de subsídio, deve-se definir o montante. O Decreto 4.541/02 exige que os descontos na tarifa de suprimento devem levar em conta as condições do mercado atendido e sua fixação de modo decrescente, para estimular a eficiência.

Um cálculo definitivo do desconto exigiria o conhecimento profundo de toda a estrutura de mercado e de custos de todas as cooperativas permissionárias, considerando sua atuação num ambiente regulado, com todos os encargos daí decorrentes. É forçoso reconhecer que isto não é possível imediatamente, pois os dados não estão completos. Talvez, enquanto não forem regularizadas, nunca estejam.

O que se propõe, então, é a fixação de um percentual de desconto inicial, provisório e estimado, baseado nos dados disponíveis (aqueles solicitados pelas Resoluções 333/99 e 012/02, atualizados para o momento), a ser calculado para cada cooperativa. Nas cooperativas onde os dados disponíveis fossem insuficientes para realizar uma estimativa mínima, poder-se-ia manter o desconto atual. Para tornar o processo de regularização ainda mais ágil, pode-se optar também por manter o atual desconto para todas as cooperativas. Manter o desconto, aliás, é o que foi feito para as duas cooperativas autorizadas já regularizadas: a CERMESO, em São Paulo e a COSEL, no Rio Grande do Sul.

Esse desconto inicial vigoraria durante um período de transição, fixado no contrato de adesão e da ordem de dois a três anos. Durante esse período de transição, com o apoio da Aneel e das agências estaduais, cada permissionária iria se adaptar tecnicamente e contabilmente às normas do setor, sujeitando-se a fiscalizações, que 
teriam caráter orientativo. Ao mesmo tempo, participariam também do processo de universalização.

Passado o período de transição, que deveria ser monitorado de perto pela agência e ser contemplado com cláusulas específicas no contrato de adesão, poderia ser definida a estrutura tarifária definitiva da permissionária, os descontos percentuais nas tarifas de suprimento e o cronograma, onde necessário, de redução dos descontos. O procedimento de fixação de tarifas poderia ser semelhante ao realizado hoje para as concessionárias, usando o modelo de empresa de referência. Simplificações nesse modelo, específicas para as permissionárias poderiam ser propostas, de modo a diminuir o ônus da regulação.

Esta solução poderia requerer alguma modificação no Decreto 4.541/02, exigindo a participação do MME, formulador das políticas públicas de energia elétrica. Essa participação deveria existir e seria bem-vinda. O período de transição e o processo de universalização iria demandar um aporte de recursos nas permissionárias, para investimento na modernização e expansão do sistema. Uma participação do MME permitiria uma negociação do financiamento desses recursos via BNDES ou Eletrobrás (RGR). A participação do MME também reduziria a resistência das cooperativas.

Esta proposta prevê que haja uma transição na absorção das cooperativas permissionárias pelo setor, ao mesmo tempo que prevê poder à Aneel para interferir diretamente e "enquadrá-las" no modelo de serviço público. Prevê também que, no período de transição, outras soluções sejam negociadas. Está em curso, dentro do governo, uma proposta de revisão do setor elétrico, que deve trazer grandes modificações no modelo atual. No bojo dessas transformações, pode-se até rever a forma de subsídio, fazendo a opção pelo segundo tipo, de repartição com todos os consumidores.

O autor julga que essa proposta de solução permitirá, em São Paulo e no Rio Grande do Sul, a regularização de todas as cooperativas num prazo não maior que seis meses. O exemplo desses estados pode ser reproduzido nas demais cooperativas do Brasil, como já vem sendo feito pela Aneel. 


\section{CAPÍTULO 10 - CONSIDERAÇÕES FINAIS}

\subsection{Regularizar ou não regularizar?}

Eis a questão. Com a regularização, uma nova etapa se vislumbra na vida das cooperativas de eletrificação rural. Serão obrigadas, provavelmente, a gestões mais profissionais, na parte financeira e também na parte técnica. A submissão às normas do poder concedente deverá trazer ganhos nas suas relações com os clientes, principalmente na parte comercial.

A sobrevivência econômica será complicada. Apesar dos mecanismos compensatórios, a tendência é que haja mais dificuldades nesse campo, pois os subsídios, quando definidos, devem prever também mecanismos para sua redução gradual. Algumas ações que têm sido consideradas pelas cooperativas de São Paulo, e que poderão representar algumas saídas, vêm a seguir:

- O compartilhamento de atividades comuns a todas as cooperativas, como faturamento, emissão de contas, assessoria jurídica, call-center, compras, entre outras.

- Formação de consórcios para produção, compra e venda de energia. A geração própria de energia, pode tanto suprir as necessidades e reduzir a dependência futura quanto se transformar em um negócio complementar, que aumente a lucratividade e compense o atendimento de mercados menos lucrativos. As cooperativas americanas investem muito no sistema de geração, e as cooperativas do Rio Grande do Sul possuem em conjunto 23,4 MW instalados em pequenas centrais hidrelétricas $(\mathrm{PCH})$, que representam um investimento de $\mathrm{R} \$ 23,8$ milhões (Stefanello, 1999). Em São Paulo, a Ceripa, em conjunto com outras duas cooperativas do Paraná, construiu a Usina Pesqueiro, de 12 MW, que entrou em operação em janeiro de 2003.

- Gerenciamento de redes rurais: as cooperativas podem se especializar no gerenciamento de redes rurais, prestando serviços para as concessionárias, que hoje possuem grandes extensões de redes rurais, próprias e particulares. A 
cooperativa, atuante no mesmo município da concessionária, poderia "tomar conta" do atendimento rural do município, usando praticamente a mesma equipe, mediante remuneração ${ }^{32}$. A CPFL, em uma das reuniões de mediação, quando indagada sobre o assunto, manifestou um certo interesse.

- Diversificação das atividades: seguindo o exemplo de algumas cooperativas de eletrificação rural específicas, as demais podem intensificar o trabalho em outras atividades, funcionando como um pólo agregador dos produtores e da área rural, proporcionando soluções energéticas para fomentar o desenvolvimento regional.

- Em alguns casos, a fusão de cooperativas que sejam próximas geograficamente, para obter ganhos de escala nas operações, pode ser bastante vantajoso. No entanto, essa solução esbarra em dificuldades políticas, pois é usual que cada cooperativa relute em compartilhar ações.

\subsection{As cooperativas de eletrificação rural e a universalização do atendimento}

\subsubsection{O debate da universalização}

O racionamento de energia elétrica de 2001 provocou grandes desequilíbrios no setor, como já se comentou. As distribuidoras contabilizaram perdas pela repentina diminuição do mercado em $20 \%$, ficando desequilibradas financeiramente. O Governo Federal propôs, então, dentro de um processo que ficou conhecido como Acordo Geral do Setor, a compensação dessas perdas através de um empréstimo do BNDES a cada concessionária, a ser pago através de um aumento adicional na tarifa.

O Acordo Geral foi implementado através de uma Medida Provisória. No Congresso, a relatoria dessa MP ficou a cargo do deputado José Carlos Aleluia,

\footnotetext{
${ }^{32}$ Em Pernambuco, as cooperativas existentes trabalham de modo semelhante. Elas possuem os circuitos de baixa tensão de vários alimentadores, recebendo autorização da CELPE para operá-los, medir e faturar os clientes, que continuam sendo da CELPE, apesar de cooperados. A concessionária paga pelo uso das redes, de acordo com a demanda e o consumo registrado pelos associados da cooperativa.
} 
professor de engenharia elétrica, que, aproveitando o interesse, tanto das distribuidoras como do Governo na aprovação do projeto de conversão, incorporou ao projeto a definição de um grande número de diferentes assuntos pendentes no setor elétrico, alguns deles já discutidos em diferentes partes do texto. Em particular, há três pontos de um antigo projeto de lei (PL 2.905/00), ligados à questão da universalização, cujos textos já faziam parte do debate do setor elétrico:

- A criação de um Programa de Incentivo às Fontes Alternativas de Energia (Proinfa) (Art. $3^{\circ}$ da Lei 10.438).

- A definição de critérios para o enquadramento na subclasse residencial baixa renda (Art. $1^{\circ}$ da mesma lei).

- A proposta de universalização do acesso, em moldes semelhantes ao do antigo PL 2.905/00 (Art. 14 e 15 da mesma lei).

Foi também criada a CDE (Conta de Desenvolvimento Energético) como fonte de recursos para custeio desses pontos. A CDE é formada pelos recursos oriundos dos pagamentos anuais realizados a título de uso de bem público, das multas aplicadas pela Aneel a concessionários, permissionários e autorizados e por quotas anuais pagas pelos agentes comercializadores (Art. 13), e tem a duração de 25 anos.

Além disso, como já mencionado, foram colocados artigos referentes a permissionários e cooperativas de eletrificação rural, bem como uma série de outros pontos que precisavam de uma lei para serem regulamentados. Assim, esse projeto funcionou como um grande "guarda-chuva" incorporando vários temas pendentes de legislação.

O projeto foi aprovado rapidamente, dado a urgência das distribuidoras pelos recursos do BNDES, e sem muitas discussões, resultando na Lei 10.438, que é o principal marco legal do processo de universalização.

Os artigos 14 e 15 fornecem as diretrizes principais desse processo, com dois enfoques distintos. O Art. 14 fornece as regras para universalização, remetendo à Aneel o detalhamento e fiscalização das regras. Em resumo, este artigo prevê que: 
- Para cada concessionária e permissionária, a Aneel deve fixar áreas progressivamente crescentes em torno dos quais a ligação ou aumento de carga solicitado pelos consumidores deve ser atendido sem ônus de qualquer espécie para o cliente. Para fixação das áreas, devem ser levadas em conta taxas de atendimento da concessionária, de forma global e desagregada por município, bem como a capacidade técnica e econômica para o atendimento das metas de universalização.

- O estabelecimento de mecanismos que possibilitem ao futuro cliente, localizados em áreas não imediatamente atendidas, a antecipação de sua ligação, mediante restituição posterior do valor investido.

- A publicidade das metas de universalização.

- O prazo de um ano para que a Aneel regulamente o artigo, sob pena de se considerar toda a área de concessão da empresa como área no interior da qual não há ônus para a ligação ou aumento de carga para qualquer cliente.

- A partir da publicação da lei, as ligações que necessitem apenas de extensão de rede secundária já são realizadas sem ônus para o cliente.

O artigo 15 introduz, complementarmente, outro instrumento para o processo de universalização: a licitação para outorga de permissões de serviço público de energia elétrica, em áreas já concedidas. Este artigo será comentado mais adiante.

O espírito da Lei 10.438 foi de finalmente introduzir a obrigação da universalização do acesso dentro do setor elétrico. Rompeu-se um paradigma que perdurava desde a constituição do setor: o de que a responsabilidade financeira pela extensão da rede ou seu reforço estava a cargo do consumidor solicitante, geralmente pioneiro, onde depois se conectavam novos consumidores a custos mais baixos. Esse paradigma foi amenizado em diversas épocas através da formação de cooperativas ou da implantação de programas de eletrificação rural que, através da formação de grupos, repartiam esse custo pioneiro, sem, no entanto, deixar de aportar recursos para a construção da linha. Entretanto, novas questões começaram a surgir: se o custo pela extensão da rede não é mais do consumidor, e sim da concessionária, e se a concessionária tem que se manter em equilíbrio econômico financeiro, de onde 
vêm então os recursos necessários? Da tarifa, ou seja, dos consumidores já conectados? Do Governo, ou seja, dos impostos pagos pela sociedade? E a participação financeira, nos termos da legislação existente, continua existindo? Ou foi automaticamente extinta? Como usar os recursos da CDE? Como identificar o mercado não atendido? Quais os prazos para universalização?

Estas e outras questões permearam o processo de regulamentação da universalização, conduzido pela Aneel e pelo Governo Federal em um período de eleições e transição de administrações, durante um ano inteiro.

No dia 23 de dezembro de 2002 foi emitido o Decreto Federal 4.541, regulamentando alguns pontos da Lei 10.438, entre eles o Art. 13, que trata da CDE, e o Art. $3^{\circ}$, sobre o Proinfa.

Um ponto importante trazido pelo Decreto foi a definição da universalização do serviço de energia elétrica num sentido mais amplo. O Art. $2^{\circ}$, inciso IX define o seguinte:

"Art. $2^{\circ}(. .$.$) considera-se:$

\section{(...)}

IX - Universalização do Serviço Público de Energia Elétrica: busca do fornecimento generalizado de energia elétrica, alcançando, progressivamente, o atendimento de consumidores impossibilitados de ser atendidos em face da distância em que se encontram das redes existentes ou da dificuldade em arcar com tarifas normais de fornecimento;"

Outro ponto foi a definição que os recursos da CDE deveriam ser majoritariamente destinados à universalização, entendida no conceito ampliado (acesso e sua sustentabilidade), cabendo à Aneel regular sua aplicação.

Na passagem de 2002 para 2003, houve a mudança de administração federal.

Em abril de 2003, perto do prazo final imposto pela Lei 10.438 para a regulamentação, a agência colocou em audiência pública uma proposta de resolução que era bastante parecida com uma minuta apresentada antes da lei, no ano 2000. O processo de audiência pública que se seguiu foi bastante rápido, e no dia 29 de abril 
de 2003 foi emitida a Resolução Aneel 223/03, já mencionada, cujos artigos dão explicitamente às concessionárias e permissionárias a obrigação da universalização, eliminando, no entanto, as cooperativas de eletrificação rural que estão em processo de regularização, conforme visto no capítulo anterior. As principais diretrizes da Resolução 223/03 são:

- Obrigação das concessionárias e permissionárias apresentarem, individualmente, um Plano de Universalização de Energia Elétrica. Este Plano deve conter Programas Anuais, descrevendo, para cada ano, o mercado a ser atendido e as áreas onde novas ligações ou aumentos de carga serão realizadas sem ônus para o consumidor.

- Os Programas Anuais devem conter, por município, metas (em km) para extensão de redes, metas para número de unidades consumidoras a serem atendidas, custo médio por ligação, formas de divulgação do plano para as populações e proposta de padrões de qualidade a vigorarem na expansão do atendimento.

- Datas para o alcance máximo da universalização, definida com base no cálculo do chamado Índice de Atendimento (Ia), que é a "razão entre razão entre o número de domicílios com iluminação elétrica e o total de domicílios, ambos obtidos a partir do Censo 2000 do IBGE”. São definidas duas datas máximas, uma para a concessionária e permissionária como um todo e outra para o município. Vale a que for menor.

- Revogação da Portaria DNAEE 05/90, eliminando a participação financeira dos consumidores.

Em relação às condições para outorga de permissões em áreas já concedidas, a Resolução repete o texto da Lei, não detalhando a questão. Na prática, é um adiamento do problema.

\subsubsection{A omissão das cooperativas de eletrificação rural no debate da universalização}

Durante todo o tempo em que se discutiu a universalização do atendimento, as cooperativas de eletrificação rural procuraram manter-se à sombra. Abdicaram de 
participar do debate nacional, justamente no período em que houve a ruptura do modelo de atendimento ao consumidor rural.

Não compareceu à tribuna.

Justo elas, que sempre protagonizaram a cena, calaram-se.

Há que se pensar.

Concessionárias se esperneando para fugir da obrigação social e cooperativas quietas. Certamente não estavam insatisfeitas com o desenrolar dos fatos. Se as concessionárias estavam se expondo ao conflito com o regulador, e se elas têm as mesmas obrigações que a lei acabava de impor às descontentes concessionárias, motivo havia de não estarem discutindo a mesma discussão.

Dizer que para elas a universalização do atendimento é uma obrigação que já cumprem, ou uma obrigação bem vinda a seu espírito de atendimento rural não condiz com a realidade: elas mostraram, em São Paulo, que não gostam de atender consumidores pobres, pois não aceitaram os apelos de participar do programa "Luz da Terra", salvo a honrosa exceção da Cetril.

Na realidade, ficaram à margem da discussão porque estão sempre à margem do setor elétrico. E no momento em que a eletrificação rural ganha as primeiras páginas dos jornais, elas ficam na sombra da regulação: as obrigações da Lei 10.438 são, textualmente, obrigações das concessionárias e permissionárias.

Enquanto elas não forem regularizadas como permissionárias, elas estão sem ter motivos para atender a essa lei.

Viva a sombra. Estar na sombra é uma forma eficiente de capturar o regulador.

Quem também vai ficar à sombra é o cidadão que mora dentro da área que não é da concessionária e que ainda não tem luz... 


\subsection{Os instrumentos da permissão e autorização como fomento à universalização}

Entre as alternativas propostas pela Lei 10.438 para a universalização, está o uso do instrumento da permissão para outorgar áreas a organizações (inclusive cooperativas) que realizarem o processo de atendimento aos consumidores ainda sem luz, por meio de expansão da rede elétrica ou uso de fontes alternativas em sistemas isolados. O Art. 15 da lei diz, textualmente:

“Art. 15. Visando a universalização do serviço público de energia elétrica, a Aneel poderá promover licitações para outorga de permissões de serviço público de energia elétrica, em áreas já concedidas cujos contratos não contenham cláusula de exclusividade.

\section{(...)}

$\S 3^{\circ}$ A permissionária será contratada para prestar serviço público de energia elétrica utilizando-se da forma convencional de distribuição, podendo, simultaneamente, também prestar o serviço mediante associação ou contratação com agentes detentores de tecnologia ou titulares de autorização para fontes solar, eólica, biomassa e pequenas centrais hidrelétricas.

$\S 4^{\circ}$ À permissionária contratada na forma deste artigo é permitido realizar o fornecimento de energia elétrica a todos os consumidores, ligados ou não, localizados na área permitida, independentemente de carga, tensão e dos prazos de carência previstos nos arts. 15 e 16 da Lei n 9.074, de 7 de julho de 1995.

\section{(...)}

$\S 6^{\circ}$ A permissão de serviço público de energia elétrica contratada na forma deste artigo poderá prever condições e formas de atendimento específicas, compativeis com a tecnologia utilizada."

Há necessidade de realização de nova regulamentação, que detalhe as condições e as características de tais novas permissões. Seguramente, a aplicação desse instrumento dependerá de como o processo de universalização se encaminhará nas concessionárias e permissionárias e da vontade política do governo.

Apenas como especulação - já que o próprio regulador acaba de jogar o problema para um futuro absolutamente incerto - o autor, quase como "post 
scriptum" deste trabalho que relata suas pesquisas e suas experiências passadas com as cooperativas de eletrificação rural, ousa apontar.

Aponta primeiro para o fato de que o legislador foi muito otimista ao imaginar que haverá sempre um agente interessado no osso que a concessionária despreza. Vai ser necessário dourar a pílula em muitos casos, ou seja, há que se prever subsídios.

Aponta também para outra questão: a aplicação do Art. 15 suscitará inevitáveis questionamentos jurídicos. Será complicado realizar um "recorte" da área de concessão da empresa e licitá-lo novamente. Se, como visto, já foi complicado fazer isso com um agente que ocupava a área há décadas, que dirá fazer isso sem nenhum agente?

Supondo que se consiga aplicar o dispositivo, o futuro permissionário deve ter claramente definido um contrato de permissão, com obrigações e direitos bem estabelecidos. O contrato deve prever, entre outros pontos:

- Uma área claramente demarcada.

- Obrigação de atendimento a todos os consumidores.

- Mecanismos de subsídio, caso seja necessário, de modo a estabelecer um equilíbrio econômico-financeiro do contrato.

- Obrigações de cumprimento à legislação do setor elétrico, com adaptações dada as características do mercado e dos sistemas a serem utilizados.

Quanto à autorização, o instrumento não pode, pois não há previsão para isso, nem deve ser utilizado, pois não é adequado para realização do serviço público de energia elétrica.

A adoção destes e outros pontos irão evitar a situação existente quando do processo de formação de cooperativas de eletrificação rural, evitando a ocorrência de conflitos futuros. 
Seguramente, as soluções para levar energia às áreas isoladas não passam pela aplicação do Art. 15 da Lei 10.438. A concessionária deve ter a obrigação de fazer o processo de universalização como estabelecido pelo Art. 14 da mesma lei e pela Resolução 223/03, sob pena de ser submetida a uma ameaça mais grave: a declaração da caducidade da concessão.

Isto não impede, porém, que soluções criativas possam ser utilizadas no atendimento a esses locais. $\mathrm{O}$ uso de fontes alternativas de energia (óleos vegetais, biodiesel, sistemas fotovoltaicos, centrais eólicas, mini e micro centrais hidroelétricas, entre outras), a contratação de Organizações Não-Governamentais, a instalação de mini-redes, a capacitação e participação da comunidade local, e até mesmo a formação de cooperativas são pontos que devem ser estudados e adaptados a cada condição local. Entretanto, a responsabilidade pelo serviço deve sempre ser de um agente de serviço público.

\subsection{Conclusão do texto}

A principal conclusão deste trabalho é que o cidadão rural da área das cooperativas de eletrificação rural, áreas que em São Paulo são identificadas por uma linha poligonal feita pelo órgão regulador, são vítimas de um inusitado absurdo criado pela atitude protelatória da Agência Nacional de Energia Elétrica. A Constituição confere ao Estado as prerrogativas do serviço público de eletricidade. A Lei de Concessões determina que a cooperativa, para ser permissionária, depende de uma iniciativa regulamentadora da mesma Agência, que a protela. Então a cooperativa está livre da classificação de permissionária, e livre do alcance da sanção que a Lei reserva a concessionárias, permissionárias e autorizados do serviço de eletricidade.

Situação paradoxal em que a área demarcada está fora do raio de ação da regulação pública. Livre de regulação justamente no tempo em que mais se ouve falar de regulação e suas pesadas multas, meio pelo qual o Estado exerce a coerção necessária para o equilíbrio entre os agentes econômicos que atuam no setor. $\mathrm{O}$ consumidor só não pode ser reconhecido como o agente que mais pena a situação 
porque o excluído que ainda não é consumidor, excluído da ligação ao sistema elétrico e excluído da conexão com a cidadania, vive contradição de muito maior perplexidade. Se já há perplexidade que uma cooperativa - existencialmente coisa da cooperação, da solidariedade, da comunidade, da coesão social - lhe exclua da eletrificação rural, é absolutamente inaceitável que não assista a ele o mesmo direito que a Lei garante a todos os outros cidadãos do Brasil, que ficam fora da poligonal, de ter luz, novela, jogo da seleção, horário político, cerveja gelada.

Superado esse obscuro paradoxo, pode-se prognosticar que os instrumentos criados para a regularização das cooperativas de eletrificação rural têm condições de colocar em ordem o setor e definir claramente as obrigações dos prestadores de serviço público.

Hoje, o governo declara que vai fazer a universalização do atendimento. É sua prioridade números 1,2 e 3 . Nesse contexto, a situação das cooperativas de eletrificação rural será inevitavelmente revista, por força do atendimento do direito de cada um de se ter acesso ao serviço público de energia elétrica.

Incorporar o cidadão da área da cooperativa ao serviço público é também uma ação de universalização. 


\section{REFERÊNCIAS BIBLIOGRÁFICAS}

AGÊNCIA NACIONAL DE ENERGIA ELÉTRICA (Aneel). Resolução Aneel no. 333, de 2 de dezembro de 1999. Estabelece as condições gerais para a implantação de instalações de energia elétrica de uso privativo, dispõe sobre a permissão de serviços públicos de energia elétrica e fixa regras para regularização de cooperativas de eletrificação rural. Brasília, DF., 1999. Disponível em: $<$ http://www.aneel.gov.br/legislação $>$.

- Resolução Aneel n ${ }^{\mathbf{0}}$ 456, de 29 de novembro de 2000. Estabelece, de forma atualizada e consolidada, as Condições Gerais de Fornecimento de Energia Elétrica.

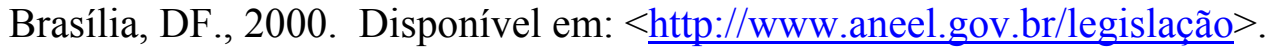

- Resolução Aneel n ${ }^{\mathbf{0}}$ 012, de 11 de janeiro de 2002. Estabelece as condições gerais para a regularização das cooperativas de eletrificação rural, nos termos do art. 23 da Lei $\mathrm{n}^{\mathrm{o}}$ 9.074/95. Brasília, DF., 2002. Disponível em: <http://www.aneel.gov.br/legislação $>$.

- Resolução Aneel no. 223, de 29 de abril de 2003. Estabelece as condições gerais para elaboração dos Planos de Universalização de Energia Elétrica visando ao atendimento de novas unidades consumidoras ou aumento de carga, regulamentando o disposto nos arts. 14 e 15 da Lei no 10.438 , de 26 de abril de 2002, e fixa as responsabilidades das concessionárias e permissionárias de serviço público de distribuição de energia elétrica. Brasília, DF., 2003. Disponível em: $<$ http://www.aneel.gov.br/legislação $>$.

- Resolução Aneel n ${ }^{\mathbf{0}}$ 236, de 20 de maio de 2003. Estabelece as condições gerais para a contratação do suprimento de energia elétrica pelas concessionárias de distribuição do Sistema Interligado Nacional, com mercado próprio inferior a 300 GWh/ano, conforme disposições da Lei n ${ }^{\circ} 10.438$, de 26 de abril de 2002. Brasília, DF., 2003. Disponível em: <http://www.aneel.gov.br/legislação $>$.

- Missão da Aneel. Brasília, 2003. Disponível em: $\overline{<\mathrm{http}: / / w w w . a n e e l . g o v . b r}>$ Pesquisa realizada em 15 de junho de 2003.

ARIMURA, O. T. et al. A educação rural sem luz. In: XIX Conferência Latinoamericana de Eletrificação Rural. Havana, Cuba, 2003. XIX CLER. CDROM.

ASSOCIAÇÃO BRASILEIRA DAS DISTRIBUIDORAS DE ENERGIA ELÉTRICA (Abradee). Ação ordinária de anulação com pedido de antecipação de tutela. . Ação judicial contra a Aneel. Rio de Janeiro, 2001, 36 p. mimeo.

BLANCHET, L. A. Concessão de serviços públicos. 2. ed. Curitiba, PR: Juruá, 1999. $324 \mathrm{p}$. 
BRASIL. Constituição da República Federativa do Brasil, de 5 de outubro de 1988. 16a. ed. São Paulo: Editora Atlas S. A., 2000.

- DECRETO n' 24.643, de 2 de julho de 1998. Código de Águas. Brasília, $\overline{\mathrm{DF}, 1} 1934$.

- DECRETO no. 41.019, de 26 de fevereiro de 1957. Regulamenta o Código de Águas. Brasília, DF, 1957.

- DECRETO n $\mathbf{n}^{\mathbf{0}} \mathbf{1 . 0 3 3}$, de 22 de maio de 1962. Brasília, DF, 1962.

- DECRETO n ${ }^{\mathbf{0}}$ 62.655, de 03 de maio de 1968. Regulamenta a execução de serviços de eletrificação rural mediante autorização para uso privativo e revoga o Decreto 1.033 de 22.05.1962. Brasília, DF, 1968.

- DECRETO no. 67.052, de 13 de agosto de 1970. Institui o Fundo de

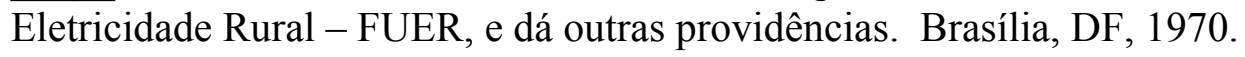

- DECRETO no. 79.898, de 30 de junho de 1977. Define o Programa Nacional de Eletrificação Rural. Brasília, DF, 1977.

- DECRETO n $\mathbf{~} \mathbf{0 . 5 4 1}^{\mathbf{0}}$, de 23 de dezembro de 2002. Regulamenta os arts. $3^{\circ}$, $\overline{13,17}$ e 23 da Lei 10.438 de 26.04.2002, que dispõe sobre a expansão da oferta de energia elétrica emergencial, recomposiçãp tarifária extraordinária, cria Programa de Incentivo às Fontes Alternativas de Energia Elétrica - PROINFA e a Conta de desenvolvimento Energético - CDE, e dá outras providências. Brasília, DF, 2002.

- LEI $\mathbf{n}^{\mathbf{0}}$ 5.764, de 16 de dezembro de 1971. Define a política nacional de cooperativismo, institui o regime jurídico das sociedades cooperativas e dá outras providências. Brasília, DF, 1971.

- LEI $n^{\mathbf{0}}$ 8.631, de 04 de março de 1993. Dispõe sobre a fixação dos níveis das tarifas para o Serviço Público de Energia Elétrica, extingue o regime de remuneração garantida e dá outras providências. Brasília, DF, 1993.

- LEI $\mathbf{n}^{\mathbf{0}}$ 8.987, de 13 de fevereiro de 1995. Dispõe sobre o Regime de Concessão e Permissão da Prestação de Serviços Públicos previsto no art. 175 da Constituição Federal e dá outras providências. Brasília, DF, 1995.

- LEI n' 9.074, de 7 de julho de 1995. Estabelece normas para outorga e prorrogações das concessões e permissões de serviços públicos e dá outras providências. Brasília, DF, 1995.

- LEI n' 9.427, de 26 de dezembro de 1996. Institui a Agência Nacional de Energia Elétrica - Aneel, disciplina o Regime das Concessões de serviços públicos de energia elétrica e dá outras providências. Brasília, DF, 1996.

- LEI $\mathbf{n}^{\mathbf{0}} \mathbf{1 0 . 4 3 8}$, de 26 de abril de 2002. Dispõe sobre a expansão da oferta de energia elétrica emergencial, recomposição tarifária extraordinária e 
universalização do Serviço Público de Energia Elétrica, cria o Programa de Incentivo às Fontes Alternativas de Energia Elétrica - PROINFA, a Conta de Desenvolvimento Energético - CDE, dá nova redação às Leis 9.427 de 26.12.1996, 9.648 de 27.05.1998, 3.890-A de 25.04.1961, 5.655 de 20.05.1971, 5.899 de 05.07.1973, 9.991 de 24.07.2000, prorroga o prazo para entrada em operação das Usinas enquadradas no Programa Prioritário de Termeletricidade e dá outra providências. Brasília, DF, 2002.

COMISSÃO DE SERVIÇOS PÚBLICOS DE ENERGIA (São Paulo). Quem somos e missão. Disponível em: $<$ www.cspe.gov.br $>$. Pesquisa realizada em 20 de abril de 2003.

COOPERS \& LYBRAND. Projeto de reestruturação do setor elétrico brasileiro: cooperativas de eletrificação rural. Relatório VI-2. Ministério de Minas e Energia / Eletrobrás. Brasília, 1997, 76 p.

- Regulamentação das cooperativas de eletrificação rural. Working Paper

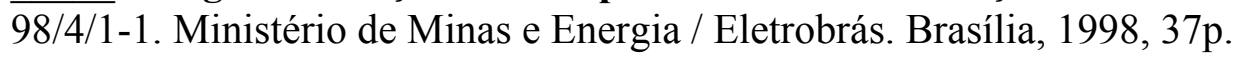

CORREIA, J. S. S. Eletrificação rural de baixo custo: avaliação e prática. Dissertação (mestrado). São Paulo, 1993, 242 p. Escola Politécnica da Universidade de São Paulo.

FRANCO, M. S. C., Homens livres na ordem escravocrata. 4a. ed. São Paulo: Ed. Unesp, 1997. 371p.

GALVÃO, L. C. R. et. al. Aspectos da geração distribuída na promoção da energizacao rural no estado de São Paulo. In: XIX Conferência Latinoamericana de Eletrificação Rural. Havana, Cuba, 2003. XIX CLER. CD-ROM.

GIRARDI, C. Evolução do direito da eletricidade: o novo direito das concessões de energia elétrica. In: EFEI/USP/UNICAMP, Cenários 2000. Módulo III - Direito da Energia. São Paulo, 2000, mimeo.

GROTTI, D. A. M. Teoria dos serviços públicos e sua transformação. In: SUNDFELD, C. A. (Org.). Direito Administrativo Econômico. Malheiros Editores. São Paulo, 2000, 406 p.

JUCÁ, A. S., PELEGRINI, M. A., RIBEIRO, F.S. A normatização técnica como indutora de reduções de custos da eletrificação rural. In: XVIII Conferência Latinoamericana de Eletrificação Rural. San José, Costa Rica, 2001. XVIII CLER. CD-ROM.

JUCÁ, C. S. et. al. Demarcação de cooperativas de eletrificação rural. In: III Congresso Brasileiro de Regulação de Serviços Públicos Concedidos. Gramado, 2003. CD-ROM.

MARQUES NETO, F. A., Agências reguladoras - instrumento de fortalecimento do Estado. São Paulo. ABAR, 2003. 66p. 
MEIRELLES, H. L., Direito administrativo brasileiro. 26a. ed. São Paulo: Malheiros Editores, 2001. 782p.

NATIONAL RURAL ELECTRIC COOPERATIVES ASSOCIATION (NRECA). Arlington, EUA. Facts about electric cooperatives. Disponível em: $<$ www.nreca.org $>$. Pesquisa realizada em 02 de fevereiro de 2003.

ORGANIZAÇÃO DAS COOPERATIVAS BRASILEIRAS (OCB). Brasília. Relatórios estatísticos do cooperativismo. Disponível em: <www.ocb.org.br $>$. Pesquisa realizada em 14 de novembro de 2002.

PAZZINI, L. H. A. et al. Universalização do atendimento de energia elétrica em áreas rurais: perspectivas do Brasil. In: XVIII Conferência Latinoamericana de Eletrificação Rural. San José, Costa Rica, 2001. XVIII CLER. CD-ROM.

• Novos procedimentos para eletrificação rural em São Paulo, Brasil. In: XIX Conferência Latinoamericana de Eletrificação Rural. Havana, Cuba, 2003. XIX CLER. CD-ROM.

PELEGRINI, M.A. Prática da eletrificação rural em São Paulo (1995-1997). Dissertação (mestrado). São Paulo, 1998, 162 p. Escola Politécnica da Universidade de São Paulo.

PELEGRINI, M. A. et al. As cooperativas de eletrificação rural no contexto da reforma do setor elétrico brasileiro. In: XVIII Conferência Latinoamericana de Eletrificação Rural. San José, Costa Rica, 2001. XVIII CLER. CD-ROM.

- Análise das diretrizes brasileiras para eletrificação rural e universalização do serviço de energia elétrica. In: XIX Conferência Latinoamericana de Eletrificação Rural. Havana, Cuba, 2003. XIX CLER. CDROM.

RECH, D., Cooperativas - uma alternativa de organização. 1a. ed. São Paulo: DP\&A, 2000. 192p.

RIBEIRO, F.S. Eletrificação rural de baixo custo. São Paulo, junho de 1993. 157p. Tese (Livre Docência) - Escola Politécnica, Universidade de São Paulo.

RIBEIRO, F. S. et. al. Avaliação econômica dos padrões técnicos utilizados em redes elétricas no estado de São Paulo. In: XVIII Conferência Latinoamericana de Eletrificação Rural. San José, Costa Rica, 2001 (a). XVIII CLER. CD-ROM.

- Os problemas do superdimensionamento das cargas elétricas rurais. In: XVIII Conferência Latinoamericana de Eletrificação Rural. San José, Costa Rica, 2001 (b). XVIII CLER. CD-ROM.

- Análise do desempenho do programa de eletrificação rural "Luz da Terra" (1997-2000). In: XVIII Conferência Latinoamericana de Eletrificação Rural. San José, Costa Rica, 2001 (c). XVIII CLER. CD-ROM. 
- Aterramento de sistemas monofilares com retorno por terra (MRT) análise pelo método dos elementos finitos. In: XVIII Conferência Latinoamericana de Eletrificação Rural. San José, Costa Rica, 2001 (d). XVIII CLER. CD-ROM.

$\because$ Uso dos instrumentos jurídicos da permissão e autorização para regularização de cooperativas de eletrificação rural e fomento da universalização. In: XIX Conferência Latinoamericana de Eletrificação Rural. Havana, Cuba, 2003. XIX CLER. CD-ROM.

ROSA, F. L.O.; RIBEIRO, F.S.; MELLO; R.S. Programa de eletrificação rural simplificado para pequenas propriedades agrícolas do Rio Grande do Sul/PROLUZ - Brasil: avaliação preliminar dos resultados. In: XIV Conferência Latino Americana de Electrificacion Rural (XIV CLER). Tomo VIII. Punta del Este, Uruguai, outubro de 1993.

SALOMÃO FILHO, C. Regulação na atividade econômica: princípios e fundamentos jurídicos. São Paulo: Malheiros Editores, 2001.

SOUTO, C. F.; LOUREIRO, G. K., O novo modelo do setor elétrico brasileiro e as cooperativas de eletrificação rural. 1a. ed. Porto Alegre. Livraria do Advogado Editora, 1999. 164p.

STEFANELLO, J. A eletrificação rural e as cooperativas. In: XVII Conferência Latinoamericana de Eletrificação Rural, Recife, 1999. XVII CLER. CD-ROM.

TEIXEIRA, N. Eletrificação rural simplificada: sistema monofilar com retorno por terra - MRT. Rio de Janeiro, BNDES, 1988. (Cadernos FINSOCIAL nº 8)

TENDRIH, L. Experiências com sistemas de eletrificação rural de baixo custo: uma análise dos impactos sócio-econômicos. Dissertação (Mestrado) Universidade Federal Rural do Rio de Janeiro. Itaguaí, Rio de Janeiro, junho de 1990. 